\title{
A construção de representações nacionais: os desenhos de Percy Lau na Revista Brasileira de Geografia e outras "visões iconográficas" do Brasil moderno'
}

\author{
Heliana Angotti-Salgueiro \\ Cátedra Brasileira de Ciências Sociais \\ Sérgio Buarque de Holanda, associada à \\ Maison des Sciences de l'Homme, Paris
}

RESUMO: A emergência disciplinar das ciências humanas, especialmente da geografia e da etnologia, caminhou, desde o início do século, ao lado da formação das coleções fotográficas e de outras séries figurativas inscritas na construção de representações nacionais internacionalmente comparáveis, ancoradas no regionalismo. Neste artigo, os desenhos de Percy Lau para a série "Tipos e aspectos do Brasil", em seção da Revista Brasileira de Geografia a partir de 1939, são colocados em relação com outras "visões iconográficas" do Brasil moderno - no caso, as fotografias dos franceses Pierre Monbeig e Marcel Gautherot. $\mathrm{Na}$ associação de imagens em séries correlatas evidencia-se uma cultura visual que se generaliza, num momento em que tanto a viagem individual como o ato de fotografar se tornam práticas cada vez mais comuns e acessíveis. A convergência de representações de uma mesma geração convida-nos a detectar na mise en serie as convenções visuais e os parâmetros do estilo documentário de uns e de outros, para que se chegue a uma síntese sobre o pensamento imagético da época. As imagens evidenciam itinerários figurativos geograficamente coincidentes resultando em representações que, por extensão e repetição, tornam-se ícones. Os tipos e aspectos da série de Percy lau e os textos que os acompanham inscrevem-se na geografia vidaliana, uma das matrizes intelectuais da geografia brasileira, em momento de sua institucionalização, em pleno Estado Novo. Se história, viagem e imagem apóiam-se no comparatismo, recuperar os modelos de conhecimento na base das representações, tecendo as persistências, apropriações, transformações e hibridismos das séries iconográficas em todos os níveis, é um vasto programa de pesquisas abertas ao diálogo interdisciplinar.

PALAVRAS-CHAVE: Iconografia geográfica. "Tipos e aspectos". Paisagem humana. Regionalismo. Imagens da nação. Geografia humana.

Anais do Museu Paulista. São Paulo. N. Sér.v.13.n.2.p. 21-72. jul.-dez. 2005.

\begin{abstract}
1. Este artigo faz parte de um projeto mais amplo sobre Marcel Gautherot financiado pela The Getty Foundation. Retomo e amplio aqui parte do trabalho apresentado primeiramente na Jornada do Museu Paulista e depois na Journée d'étude Paysage et territoire, organizada por Marie-Vic Ozouf-Marignier e Alice Ingold em Paris, a 10/1/2005, relativa ao livro de François Walter (2004).
\end{abstract}


ABSTRACT: The disciplinary emergence of the human sciences, specially Geography and Ethnology, has evolved, from the beginning of the century, alongside the formation of photographic collections and other figurative series inscribed in the construction of internationally comparable national representations, anchored on regionalism. In this article, Percy Lau's drawings for the series "Types and Aspects of Brazil", in a section of the Revista Brasileira de Geografia magazine from 1939 onwards, are compared to other "iconographic views" of modern Brazil - in this case the photographs by Frenchmen Pierre Monbeig and Marcel Gautherot. A visual culture in the process of generalization is highlighted in the association of images in correlated series, at a moment when both the solo journey and the act of photographing ad become increasingly common and accessible practices. The convergence of representations by one same generation invites us to detect in the mise-en-serie the visual conventions and the documentary style parameters of one and the other, so that a synthesis of the imagistic thought of the era is arrived at. The images evidence geographically coincident figurative itineraries, resulting in representations that, by extension and repetition, become icons. The types and aspects of Percy Lau's series and the texts accompanying it are inscribed within the Vidalian geography, one of the intellectual matrices of Brazilian geography, in its moment of institutionalization, during the Estado Novo period. If history, travel and image lean on comparativeness, weaving persistencies, appropriations, transformations and hybridisms of the iconographic in all levels, then it constitutes a vast research program open to interdisciplinary dialogue.

KEYWORDS: Geographic lconography. "Types and Aspects". Human Landscape. Regionalism. Images of Nation. Human Geography.

Observações introdutórias sobre o contexto cultural dos "tipos e aspectos" se impõem para situar o leitor no cenário internacional.

Como as ciências humanas em vias de estruturação desde o início do século se voltam para o local/rural/regional? A geografia e a etnologia parecem ter sido convocadas pelas políticas culturais em prol dos movimentos regionalistas. Esses movimentos, diga-se de antemão, são internacionais, mais ou menos sincrônicos, no final do século XIX e no período entre guerras - há vários estudos em outros países sobre a questão. No caso da França, AnneMarie Thiesse (1995, 1997, 1998, 2001) assina os que nos interessam mais de perto, relativos às representações de identidades nacionais. Sobre a questão das paisagens, território e identidade nacional, o livro de François Walter (2004) é a referência mais recente.

Desde o século XIX, os lugares em que se exibe o interesse pela "cor local", especificidades regionais e imagens de cada nação, tipos humanos, habitação, folclore, são as exposições universais e nacionais, cujos estudos a respeito são conhecidos - não retomarei a questão, salvo em relação a alguns aspectos do período que nos interessa: os eventos de 1937, em Paris. Retrospectivamente, na França, a campanha fotográfica para constituir Les Archives de la Planète resultou numa das mais importantes coleções fotográficas no gênero "tipos e aspectos", em que se visava o "inventário das diferenças de um mundo em vias de urbanização", ou o "registro dos costumes locais em vias 
de desaparecimento". Assim, são as cenas rurais que vão dominar as temáticas típicas da geografia humana dos herdeiros de Vidal de La Blache lobserve-se, porém, que na coleção do Museu Albert Kahn, o Brasil figura com panoramas de cidades, em que predominam as paisagens do Rio de Janeiro: as viagens ao hinterland não teriam sido feitas). Devemos reter, sobretudo, que a emergência das ciências humanas - a arqueologia, a geografia, a etnologia - caminha ao lado da formação das coleções fotográficas.

No estudo da trajetória de Marcel Gautherot, a contextualização das suas experiências vividas nos anos 1930, na Europa, revela-se necessária e fecunda. Em 1937, sabíamos apenas que ele estava ligado ao Musée de l'Homme, tendo feito aí experimentos fotográficos e participado como arquitetodecorador de exposições etnográficas - a informação na cronologia do catálogo do Instituto Moreira Salles de 2001 se restringia a isso. Ao estudarmos o período, vimos que neste ano de 1937 acontece em Paris a Exposição Internacional de Artes e Técnicas, dominada pelo regionalismo, que se desdobra em eventoschave como o primeiro Congresso Internacional de Folclore, cuja publicação das atas fica a cargo do Musée des Arts et Traditions Populaires, instituição recém-criada por Georges-Henri Rivière, que tem sido bem estudado². Mencionese ainda a importância do Musée de l'Homme, dirigido por Paul Rivet, que assume um papel de coordenador de pesquisas sobre o local/regional. $\mathrm{Na}$ publicação do congresso do folclore de 1937, os temas dos estudos são habitat rural, mobiliário, agricultura, artesanato, práticas agrárias, alimentação, meios de transporte, civilização material. Grandes historiadores, geógrafos, etnólogos, folcloristas e outros intelectuais reúnem-se em torno de projetos como esse congresso e a Encyclopédie Française (trabalho de registro fotográfico muito representativo), organizam eventos e assinam textos. Entre eles: Lucien Febvre, Marc Bloch, Henri Berr, Albert Demangeon, Pierre Deffontaines, Max Sorre, Raoul Blanchard, Roger Dion, Marcel Mauss, Jacques Soustelle, Henri Focillon, Georges Dumézil, André Schaeffner, Arnold van Gennep, o arquiteto Louis Bonnier - esses são apenas alguns nomes cuja importância chegou até nós.

Nesse universo encontramos um clichê de Marcel Gautherot abrindo o caderno de fotografias dos Travaux du jer Congrès International du Folklore; Gautherot, ligado ao Musée de l'Homme como arquiteto-decorador ${ }^{3}$, fotografa então a nova museografia dos projetos de reorganização das exposições sob a direção de Paul Rivet. Se não pudemos ainda apurar exatamente o tipo de trabalho feito por ele no Musée de l'Homme los arquivos e fototeca da instituição estão lamentavelmente fechados à pesquisa por tempo indeterminado), duas evidências confirmam a atuação de Gautherot como fotógrafo de espaços expositivos: a mencionada fotografia que capta a entrada de exposição relativa à casa rural francesa ${ }^{4}$, em uma sala do Musée d'Art Moderne, e fotografias de esculturas de Picasso na entrada do pavilhão da Espanha, na Exposição de Paris de 1937 (publicadas na célebre revista da vanguarda parisiense dos anos 1930, Cahiers d'Artt5. $O$ historiador sabe que as relações se tecem por essas pequenas evidências.
2. Sobre Rivière ver GORGUS, 2003 e alguns capítulos de LEBOVICS, 1995 (cuja edição original em inglês é de 1992).

3. Encontrei o registro de Marcel Gautherot freqüentando os ateliês de arquitetura da École des Arts Décoratives, de 1925 a 1927 , em documentação depositada nos Archives Nationales. Ver a respeito a apresentação da jornada que coordenei em Paris a 13/12/2005, em número especial do Cabiers du Brésil Contemporain, a ser organizado em 2006.

4. O conteúdo da exposição estava a cargo do geógrafo Albert Demangeon e a museografia coube a Georges-Henri Rivière; deve haver outras imagens de Gautherot da ocasião, pois além da que está no volume sobre o congresso de folclore, há outra publicada no livro citado sobre Rivière, $L e$ magicien des vitrines (Gorgus 2003), foto da coleção do Musée des Arts et Traditions Populaires/RMN,em que o crédito lhe é também atribuído.

5. Observe-se que as fotografias de Gautherot no Cahiers d'Art não são assinadas como acontece com outras de Dora Maar, na mesma revista, também referentes a obras de Picasso.A atribuição a ele se deu por uma coincidência da pesquisa: havíamos visto as fotos no seu arquivo no IMS, no Rio de Janeiro, sem nenhuma identificação de lugar e data, mais tarde, folheando a revista nos arquivos de Paris, as reconhecemos. 
6. Ver FAURE, 1989 (especialmente o prefácio de Pascal Ory).

7. A pesquisa em andamento de Maurício Lissovsky e Beatriz Jaguaribe

"A obra getuliana e a modernização do olhar no Brasil" foi apresentada na segunda jornada "Representações do Brasil: séries, coleções e apropriações editoriais da fotografia nos anos 1940/1960", organizada na UFF em dezembro de 2004

8. Lygia Segala observa que no Brasil o movimento folclórico impulsionado pela Comissão Nacional de Folclore, criada em 1947, esforçou-se pela mobilização da opinião pública em torno de temas da identidade nacional e cultura popular. Cf. SEGALA, 1999.

9. Sobre as relações entre a etnologia e a geografia, indispensáveis de se conhecer no caso deste estudo, ver ROBIC, 2004

10. Cf. GARCIA Jr., 1993 e PONTES, 1989.

11. Cf. VLACH, 2000.
Marcel Gautherot vem para o Brasil em 1939, meses depois é convocado, serve na África e volta para cá definitivamente depois do primeiro armistício, em 1941. Uma vez estabelecido no país insere-se em redes de relações, freqüentando artistas e intelectuais de várias tendências, muitos deles ligados ao Partido Comunista (Jorge Amado, Oscar Niemeyer, entre outros); uma atenção será dada no texto da colega Lygia Segala à suas relações com Edison Carneiro e às particularidades do folclore no Brasil, tema de um bom número de séries fotográficas que Gautherot produzirá aqui.

Na França, sob a ocupação alemã, o folclore oficial foi impulsionado pela relação regionalismo/propaganda - ver a política cultural de Vichy quando são privilegiadas as imagens de uma sociedade rural, na esteira de movimentos sociais anteriores e instituições museográficas, entre eles o Front Populaire e o mencionado Musée des Arts et Traditions Populaires, movimentos marcados pelas ambigüidades gauche/droite do final da Terceira Repúblicab'.

Em contraponto, o estudo da era getuliana é particularmente interessante como cenário em que se dá o mapeamento cultural do país, a criação do Departamento de Imprensa e Propaganda (DIP), os programas educacionais, a expansão de agências jornalísticas e estúdios fotográficos com diferentes projetos de registro e difusão da brasilidade?. Vimos que na França as incursões interioranas, viagens de aprendizado para formular as ambientações ou quadros vivos nas exposições ${ }^{8}$, os museus de etnografia e os museus "en plein air" representativos de cada uma das províncias, constituíram uma das bases do registro dos "tipos e costumes" de cada pays; nesse registro, não raro associavamse os itinerários intelectuais de porta-vozes da geografia cultural e etnólogos ${ }^{9} \mathrm{e}$ ainda os de outros homens - pintores, desenhistas e fotógrafos - de uma geração cujas práticas de representar as "paisagens humanizadas" la expressão remonta a Vidal de la Blache) nacionais ultrapassava fronteiras.

"Tipos e aspectos do Brasil" são pequenos textos, acompanhados, cada um, de uma imagem desenhada, que começam a circular em 1939, em seção da Revista Brasileira de Geografia criada em 1938 e publicada pelo Conselho Nacional de Geografia (CNG) e pelo Instituto Brasileiro de Geografia e Estatística (IBGE), duas instituições que nascem no final da década de 1930. Trata-se de uma época marcada por uma política cultural nacionalista que une a história e a geografia num élan de conhecimento do país, inscrito em um movimento de idéias pela formação da "consciência nacional" em vários campos da cultura, educação e ciências sociais, movimento de idéias alimentado por um "mercado editorial em forte expansão" 10 . Afirma-se que o caminho escolhido pelo poder político para criar uma nação era o reforço do espírito nacional, materializado na unidade do território, em que os geógrafos e a geografia assumiram um papel de destaque" .

A geografia é, então, uma disciplina que se organiza e se renova com a instalação dos primeiros cursos universitários, em São Paulo e depois no Rio de Janeiro, a edição de manuais escolares destinados à rede nacional de 
escolas públicas recém-criadas, a fundação de associações e periódicos, cujo objetivo - no caso específico da Revista Brasileira de Geografia - era "'contribuir para um melhor conhecimento do território pátrio, difundir no país o sentido moderno da metodologia geográfica [e estimular] a produção geográfica de qualidade' [na via] da 'geografia explicativa'"12.

A observação do meio físico e de sua relação com a vida humana estava explícita no texto de apresentação da $R B G$ onde se lia também que uma de suas "missões" em nome da ciência geográfica moderna era a difusão rápida e internacional do estado dos conhecimentos geográficos no Brasil - a revista afigura-se então como um instrumento de intercâmbio para o país internacionalizarse. Essa tendência à internacionalização é típica do entreguerras, e não só no Brasil, e os veículos são as pessoas, os congressos, as associações, as revistas, as imagens.

Entre os momentos fortes que antecedem o CNG, O IBGE e a mencionada revista, lembremos a participação do Brasil no Congresso Internacional de Geografia em 1931, em Paris, promovido pela Union Géographique Internationale, e a visita, pouco depois, em 1933, de Emmanuel de Martonne ao Rio, destacando em seu discurso a "riqueza e a variedade de temas geográficos [deste] extenso país" (E. de Martonne, que fez uma carreira internacional, voltará ao Brasil em 1939); em terceiro lugar, acrescente-se o papel decisivo de jovens professores universitários franceses, Pierre Deffontaines e Pierre Monbeig, que criam a Associação dos Geógrafos Brasileiros e que se unem à geração de intelectuais autóctones, geração plena de projetos, formada por homens abertos a uma cultura plural e empenhados em uma verdadeira redescoberta do Brasil, a partir de um conhecimento vivido, baseado nas viagens pelo interior do país: excursões geográficas e trabalho de campo passam a ser o ponto alto das novas orientações didáticas. Enquanto isso, as viagens com fins de registro fotográfico se generalizam bem além da geografia institucional. O significado da "viagem moderna", das experiências de deslocamento, de narrativas e visualidades coletadas, temas de literatura e iconografia, são questões a aprofundar, conforme observei na Introdução deste dossiê. E mais especialmente, partindo de corpus de imagens aproximadas por uma mesma historicidade para avançar a questão de convenções de representação do Brasil que se forjam neste momento.

Ainda nesse contexto de aparecimento oficial e disciplinar dos "tipos e aspectos", em 1933 foi criada uma seção de Estatística Territorial no Ministério da Agricultura, cujo objetivo explícito era "reunir documentos [cartográficos] sobre o território nacional e estudar as características fisiográficas das regiões"; e em 1937, no decreto de adesão do Brasil à Union Géographique Internationale, assinado por Getúlio Vargas - adesão que deve muito ao papel de Pierre Deffontaines e ao de Emmanuel de Martonne -, reafirma-se, no art. 1, o objetivo de "ativar uma cooperação geral de todos por um conhecimento sistematizado do território e da pátria". Ora, o fato de ter começado meu texto pelo registro
12. Precede esse periódico a revista Geografia, editada em São Paulo, que circula em 1935 e 1936. Nela é que se publica o Pequeno guia do viajante ativo, assinado por $\mathrm{P}$. Deffontaines e C.A. Barbosa de Oliveira (1936), com desenhos deste, sugestivo artigo que ensina o que deve ser observado na paisagem brasileira e o que registrar da ação do homem. Deffontaines como se sabe é autor de um best seller dos anos 30/40 em francês com o mesmo título Petit guide du voyageur actif (cuja primeira edição é de 1938 e a segunda de 1943), guia que também ensina "como conhecer e compreender uma região" mediante a prática típica da escola francesa de geografia:as pesquisas de campo para elaboração das monografias locais. Esse guia, destinado a associações da juventude e escoteiros, inscrevese no interesse pelo conhecimento e reconstrução das regiões francesas no entreguerras; graficamente revela inovações sendo fartamente ilustrado com fotos e croquis. 
13. FARIA, 1995. O autor reconhece fases anteriores a 1930 para o nacionalismo como política de Estado.

14. WALTER, 2004

15. A expressão é de Didier Mendibil, especialis-

ta em estudos sobre a iconologia geográfica, que mencionarei mais adiante. dessa preocupação oficial pelo conhecimento do país, não quer dizer que considero tal conhecimento e seus desdobramentos como uma ideologia exclusiva do Estado Novo - mesmo se este acentua o projeto político de construção do Estado-Nação que nasce oficialmente com a Revolução de 1930 e alimenta um projeto cultural inigualável na história do Brasil. $\bigcirc$ nacionalismo marca a política de Estado, é verdade, com gestos de proteção cultural e de consolidação de figuras identitárias, mas, em primeiro lugar, sabe-se que a busca desse tipo de conhecimento, o registro e a afirmação de representações nacionais e os inventários em geral, bem como a descrição e fixação de etnotipos lque engloba traços físicos e psicológicos que tipificam a raça, o caso brasileiro se caracterizando pela insistência no "caldeamento"), ocorreram em quase todos os países ocidentais, cada um no seu tempo próprio - há em todo lugar um processo comparável de elaboração de identidade cultural. No Brasil a questão está no ar desde o começo do século ${ }^{13}$ e é conduzida por intelectuais que saem dos mais diversos meios, reforçada pelos escritores regionalistas e pelos arautos do movimento moderno nos anos 1920, sem mencionar gestos precedentes, do romantismo oitocentista, dos circuitos imperiais às expedições etnográficas do começo do século XX. Em segundo lugar, ao fazer história cultural não estou convencida que a interpretação política explique por si só a produção e convencionalização de representações. Porém, é um fato a não negligenciar, que o país nunca viveu uma época tão marcante de voluntarismo de autorepresentação, de política cultural e pedagógica consciente e organizada em várias frentes do conhecimento e de construção de imagens emblemáticas.

Em todas as circunstâncias ou conjunturas nacionais, para lá dos lugares comuns dos discursos, as "figuras paisagísticas" da nação merecem um enfoque mais conforme às leituras recentes das ciências sociais. Lendo François Walter $^{14}$, que cita análises de Marcel Roncayolo sobre a cidade, aprendemos que, melhor do que tomar a série "Tipos e aspectos do Brasil" como puro "reflexo" ideológico do Estado Novo, seria mais fecundo vê-la como um sistema de idéias, de cultura, cujo sentido está tanto no olhar dos que representam os tipos desenhistas e fotógrafos - quanto neles mesmos.

Após situar o momento de voluntarismo e entusiasmo pelo conhecimento do país, passo às imagens, ligando-as às teorias da escola francesa de geografia, a noções vidalianas convocadas pelos seus herdeiros e citadas nos textos que acompanham os desenhos, encadeando-os com séries de imagens semelhantes, procedentes de outras coleções, especialmente fotográficas la de Pierre Monbeig e a de Marcel Gautherot). Interessa-me mostrar os contextos de "vizinhança visual"15 entre representações procedentes de experiências de viagem de indivíduos que produziram imagens-tipo próprias de uma geografia cultural com vocação etnográfica e entender o percurso da representação ao ícone e desse aos textos e vice-versa, a passagem das cenas escolhidas pela objetiva de fotógrafos, geógrafos, escritores e desenhistas como Percy lau ao estatuto de convenção. Desdobrando-se em séries, as representações de identidades territorializadas se transformam em emblemas autorizados ou ícones nacionais. 
Os desenhos de Percy Lau ${ }^{16}$ fazem parte de uma visão iconográfica do Brasil la expressão é de Alceu Amoroso Lima no prefácio ao livro de fotos de Antoine Bon, Marcel Gautherot e Pierre Verger, Brésil, citado na Introdução do dossiê), de tipos e cenas emblemáticas, na linha de uma imagerie regionalista ancorada na paisagem, imagerie que se constitui na longa duração em circuitos que passam pelo Estado, intelectuais, artistas, viajantes.

Percy Lau, cujo pai era inglês, nasceu no Peru em 1903, mas passou a maior parte de sua vida no Brasil, onde fez carreira como desenhista e ilustrador. Está em Pernambuco desde 1921 e participa do Grupo dos Independentes, organizando em 1932, com Augusto Rodrigues, o Ateliê de Artes Plásticas; no Rio de Janeiro integra em 1939 a equipe dos funcionários do IBGE. Malgrado sua mobilidade reduzida, viajou pelo Brasil a serviço do instituto, mas alguns de seus desenhos a bico-de-pena da série não são apenas fruto das viagens, tendo trabalhado também a partir de fotografias; freqüentou pintores como Portinari, Guinard, Dianira, além de Augusto Rodrigues, intérpretes como ele dos arquétipos brasileiros. Seria interessante aprofundar as relações entre seus desenhos e os produtos do meio artístico. E ainda, levantar os níveis da difusão de sua série nos manuais didáticos e em outros veículos.

Análises recentes vêm situando na historiografia a associação de aspectos de uma paisagem específica a seus tipos, a ligação dos caracteres dos habitantes ao território (determinismo ambiental), reconhecendo os momentos dessa retórica passadista que produzia estereótipos (os etnotipos)17. "A análise dos estereótipos nacionais ou do 'caráter das nações', como se dizia na Europa clássica, é um dos florões da literatura comparada [...] este enfoque destaca as relações dinâmicas que unem um caráter a um lugar", cruzando-se espacialidade e comportamento, topografia e antropologia ${ }^{18}$. As formas de construção das visões iconográficas do Brasil inscrevem-se em elaboração mental cujos pontos comuns, repito, podem ser detectados em outros países.

As cenas e textos em série sob o título "Tipos e aspectos do Brasil" começam a circular na Revista Brasileira de Geografia a partir do n. 4, em 1939, sem a sistematização dos tipos por regiões que marcará sua disposição quando reunidos em livro. $O$ número de exemplares aumentou progressivamente ${ }^{19}$, as edições respondendo a uma demanda crescente, conforme a nota explicativa da tradução francesa, que saiu em 1957. Seu tradutor, Francis Ruellan, geomorfólogo que chegou ao Brasil em 1940 para lecionar nos cursos de graduação em geografia, atuou como consultor técnico do Conselho Nacional de Geografia, foi um dos principais introdutores do trabalho de campo no país, chefiando inúmeras excursões geográficas; participou em 1948 da comissão de estudos para escolher o sítio da futura capital do país, Brasília, publicando o artigo Quelques problèmes de l'expédition chargée de trouver des sites pour la nouvelle capitale des États Unis du Brésil no Bulletin de l'Association des Géographes Français. Com sua mulher, Anette Ruellan, que se associa a ele na tradução de "Tipos e aspectos", publicou o livro Le Brésil laliás, o título se repete em livro de Pierre Monbeig, em 1954, da célebre coleção Que sais-je? da PUF, traduzido no mesmo ano pela Difusão Européia do Livro, reeditado muitas vezes
16. Em 1986, o Museu Nacional de Belas Artes, que guarda parte do arquivo de Percy Lau, dedicou-lhe uma exposição. Ver XEXÉO, 2000.

17. Cf. WALTER, 2004, capítulo Caractères et stéréotypes: du moral au spatial e p. 465 ss.

18. Id., p. 35-36.

19. Em 1940, há uma tiragem reduzida, pequena brochura contendo oito tipos, por ocasião da XIII Feira Internacional de Amostras; em 1942, contam-se 20 tipos numa edição da revista "consagrada ao batismo" da nova capital de Goiás, Goiânia; em 1943, editam-se 26 tipos nas comemorações do primeiro centenário do IHG do Uruguai; em 1944, 36 tipos circulam na tiragem da Segunda Reunião Pan-americana sobre Geografia e Cartografia, no Rio de Janeiro. Note-se que são todas edições circunstanciais visando a difusão de uma imagem do país, fixada nos seus tipos e aspectos, predominantemente rurais. Quanto à circulação da $R B G$, ela era considerável para a época: trimestrial, com uma tiragem de 5 mil exemplares e com resumos dos artigos em francês, inglês e esperanto. 
20. Paul Vidal de la Blache teria ido mais longe na análise das representações da metonímia da parte como caracterização do todo territorial no Tableau de la géographie de la France, articulando a"escala local e a mundial, o solo e os homens, o meio e a história". Ele teria criticado "o localismo exacerbado de muitos pedagogos que defendiam o estudo da petit patrie para conhecer e amar a grande [...] Longe de se reduzir à descrição infinita do mosaico dos petits pays da França, longe de evocar os gêneros de vida correspondentes às atividades tradicionais de agricultor, de criador ou outra, o Tableau se inscreve nos delineamentos de uma geografia geral do político [...] e traça também uma teoria ou pelo menos um esboço da territorialidade humana, analisando processos gerais de espacialização econômica e de representação simbólica dos lugares". Para Vidal de la Blache há, pelo menos, duas formas de territoria lidade (expressão que significa uma apropriação do espaço): uma centrada sobre o poder do Estado e outra sobre a experiência da vida cotidiana. Ele valoriza a territorialidade civil em relação à territorialidade estritamente política, da qual ele recusa o arbitrário. Enfim, ele evoca as áreas de civilização comum." Cf. ROBIC, 2000, p. 184 e 223 . Ao ler textos como esse, fica patente a necessidade de uma análise mais fina dos empréstimos aos teóricos da escola francesa feitos em textos e séries iconográficas da geografia humana brasileira,trabalho que vai muito além de uma pesquisa individual e dos limites deste ensaio.

21. THIESSE, 1997, p. 56. e com tradução até em japonês); Le Brésil é ainda título de livro de Maurice Le Lannou, em 1955, publicado também por uma editora francesa de prestígio, Armand Colin (cito esses títulos para chamar a atenção sobre o boom de publicações de estrangeiros sobre o país no período). Le Lannou (1906-1992) é normalien, figura de destaque da geografia humana francesa voltada para os estudos regionais e bom fotógrafo, interessando-se justamente pelas paisagens e as maneiras como os homens viviam nelas (I'homme-habitant) - ele esteve também no Brasil como professor, sendo um entre tantos intelectuais viajantes cujas trajetórias se conhece pouco. Aliás, sabe-se pouco também sobre a maioria dos autores que assinam os textos dos "Tipos e aspectos", de formação diversa, alguns sendo responsáveis por vários episódios, como José Verissimo da Costa Pereira, Elza Coelho de Souza, Lindalvo Bezerra dos Santos e o mais conhecido hoje, Nelson Werneck Sodré.

Em 1945 e 1946, "devido à acolhida elogiosa e simpática no exterior", saem três edições em línguas estrangeiras - inglês, esperanto e espanhol -, confirmando o objetivo de difundir as expressões culturais do Brasil, objetivo assumido pela CNG. Na nota explicativa da edição francesa, lemos que a tradução da sexta edição em português é publicada por ocasião da reunião do XVIII Congresso Internacional de Geografia, no Rio de Janeiro, em agosto de 1956: "Jamais haverá oportunidade comparável", dizia-se "para o encontro dos maiores especialistas seduzidos pelos problemas geográficos do Brasil, que pretendem estudar" (p. VII). As reedições ou edições ampliadas acontecem, então, quase todas em reuniões internacionais e reforçam minha hipótese, a do inventário e difusão de cenas do país, de seus homens e aspectos, objetivo da revista e das instituições de vocação geográfica. Estas querem afirmar e exportar a cultura e as imagens do Brasil - não se trata então unicamente da construção de imagens para circulação interna e afirmação da unidade nacional formulações da mesma ordem, repito, estão ocorrendo numa dimensão internacional. Resta-nos recuperar a lógica das escolhas dos tipos exemplares retratados. Nesta análise utilizei a edição de 1956, que mostra 96 quadros. Uso, no fim deste ensaio, apenas um "aspecto" da décima edição brasileira de 1975, já com 143: o aumento das cenas/tipos confirma o sucesso da publicação.

Ao passar para a forma de livro, os Tipos e aspectos são agrupados por grandes regiões - na revista não havia essa sistematização, eles foram aparecendo salteados: em outubro de 1939, a série começa com os "arpoadores de jacarés" da região Norte; em janeiro de 1940 o tipo é o "vaqueiro de Marajó" e o aspecto a "caatinga", que não lhe corresponde; em abril, "o gaúcho" e os "campos de criação no Rio Grande do Sul", respeitando-se nesse caso a associação do tipo à sua paisagem. É bom lembrar que a primeira divisão regional oficial data de 1941. Na lei geográfica para organizar as regiões, observa-se que se o país não era homogêneo, era necessário estudar antes as partes para depois chegar a uma síntese final ${ }^{20}$. Isso nos faz pensar em uma observação de Anne-Marie Thiesse sobre a França: fazer conhecer a petite patrie para melhor apreender a grande Pátria ${ }^{21}$. A idéia de construção analítica das 
representações ao longo do tempo se explicita, como um aprendizado sur le vif, no prefácio à edição de 1956: "depois de dezesseis anos de esforços publicando a série, o CNG já aprendeu a agrupar e a caracterizar o essencial das paisagens e dos gêneros de vida brasileiros" ${ }^{\prime 22}$.

Na viagem moderna, a fotografia é a companheira da liberdade e da mobilidade, no caso dos geógrafos e etnólogos as coleções têm em comum o fato de terem resultado de "observação participante", fotografias originárias das excursões e do trabalho de campo que ora se banalizam; a presença da fotografia nas revistas de geografia citadas é um fato digno de registro, também carente de estudos ${ }^{23}$. Fotografia e desenhos entram numa era de reprodução e consumo já conhecidos. Em 1939, quando começam a circular os Tipos e aspectos, há um artigo de Deffontaines ("A geografia humana do Brasil"), publicado em partes ao longo do ano, que exibe fotografias com a chancela do Departamento de Imprensa e Propaganda, mostrando cenas que serão igualmente representadas na série de Percy Lau.

Passo à análise dos desenhos de alguns episódios, às fotografias com representações semelhantes e aos comentários dos textos que acompanham os primeiros.

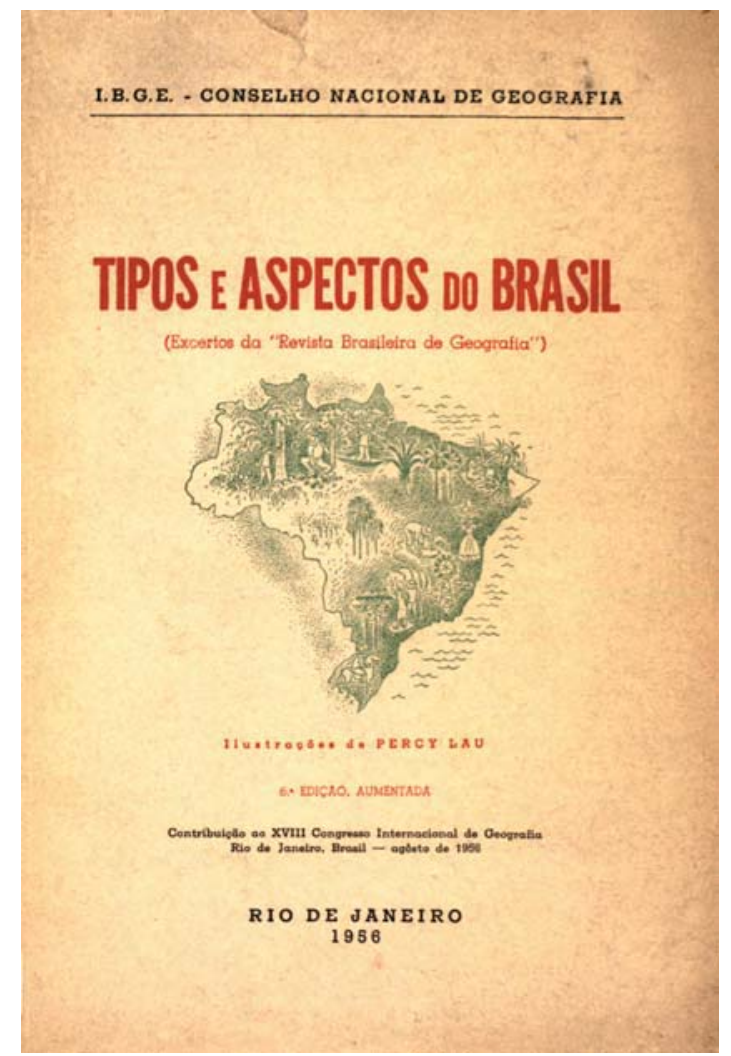

Figura 1 - Capa da edição de 1956 de Tipos e aspectos do Brasil, destacando as miniaturas das representações que sugerem regionalização, porém sem delimitação administrativa. Acervo da biblioteca do Instituto de Estudos Brasileiros da Universidade de São Paulo.
22. É bom lembrar que o IBGE tem um arquivo fotográfico sob a rubrica Tipos e aspectos, que serviu também como outras coleções do órgão (as provenientes dos trabalhos de campo) para reunir imagens para a Enciclopédia dos municípios brasileiros, editada entre 1957 e 1964; as fotos são agrupadas por Estados do Brasil,com o predomínio dos do Norte e Nordeste e malgrado a classificação deficiente contam com indicações ora da expedição, ora do fotógrafo, algumas são datadas, e os temas cobrem praticamente os mesmos da série citada. O IBGE queria fazer um museu paisagístico do Brasil, na linha dos ecomuseus europeus como o Museu de Artes e Tradições Populares; o Museu Nacional teria seguido essa linha.

23. Entre os artigos da revista Geografia, destaco, Impressões de viagem ao longo do Rio Paraná, de Antonieta de Paula Souza, narrativa de excursão feita com seus professores Pierre Monbeig e Claude Lévi-Strauss em 1936, que apresenta 12 fotografias sem autor, do maior interesse, nos códigos da geografia e da antropologia. 
24. Cf. DAOU, 2000. A autora retomou esse trabalho na Segunda Jornada sobre Representações do Brasil realizada na UFF (citada na Introdução) em 2002. Meu texto deve muito ao dela, embora tome outras direções. Agradeço-lhe as discussões fecundas a respeito.

25. Pierre Deffontaines Pays e paysages de l'état de Saint-Paul. Première esquisse de division régionale, Annales de Géographie, t. XLV, 1936, publicado em português na revista Geografia, n. 2, ano I, 1935 (as imagens diferem entre as duas edições, as da edição francesa são placas de vidro conservadas em Paris) Discípulo de Jean Brunhes, Deffontaines é autor de um interessante texto, Les personnagestypes du Brésil, Revue de Deux Mondes, de fevereiro de 1936. Ele explica que a definição humana de uma região é dada pelos "gêneros de vida" expressos nos personagenstipo e nas formas como eles se associam, exploram e vivem no seu território. E que ocupações e regime de trabalho são inscritos na paisagem. Porém, seus tipos diferem dos da série que estou tratando: ele identifica, ao longo da história, o fazendeiro como personagem principal, os índios que restaram da "hecatombe", depois o colono que gravita em torno do fazendeiro e os mascates, cuja importância aumenta com a evolução das cidades, enquanto à margem delas, no sertão, vivem os caboclos ou caipiras mestiços, o caiçara e em contraste com eles, novos personagens: os operários industriais das cidades, na maioria estrangeiros, e a nova aristocracia urbana; observa ainda que mesmo entre os pequenos métiers ur-
Na capa vê-se o mapa do Brasil, o contorno do todo: a unidade do país é representada sem as divisões dos estados no espaço territorial. Na sua interpretação pioneira da série dos Tipos e aspectos, Ana Daou o situa como um produto da política cultural do Estado Novo, observando que o mapa figurado sem definições regionais impõe a unidade à fragmentação ${ }^{24}$. Como exemplo simbólico de uma política cada vez mais centralizadora após 1937, ela lembra no seu estudo que se queimam as bandeiras de cada estado e proclama-se a bandeira nacional como o único emblema do país.

Quanto à questão da caracterização das regiões, será que se podia falar disso claramente, se no momento elas estão ainda em vias de se constituir? Para o estado de São Paulo, conhecemos o artigo de Pierre Deffontaines de 1936 em que ele tenta fazer o esboço de uma divisão regional, sem sucesso ${ }^{25}$. Nicanor Miranda, do Departamento da Cultura de São Paulo, havia afirmado no Congresso de Folclore em Paris, em 1937:

Nós não temos, na verdade, neste momento, uma base objetiva para a delimitação das regiões. As divisões regionais comumente admitidas são muito gerais e incompletas [...] histórica e geograficamente, os critérios não aparecem claramente e definitivamente estabelecidos [...]. O estudo da distribuição geral dos fatos, deve preceder a determinação das áreas, sobretudo em país como o nosso, onde tais pesquisas são absolutamente novas ${ }^{26}$.

Na verdade não só faltam pesquisas naquele momento em vários campos, como a ocupação do território está se fazendo, razões combinadas da dificuldade de um recorte regional de uma "sociedade em movimento" (expressão da época, de Pierre Monbeig). No entanto numa linguagem da antropogeografia ou da geografia cultural, o regionalismo e os caracteres vernaculares são reiterados em cada episódio pela acentuação das diversidades paisagísticas, embora não se possa reconhecer em todo lugar um pertencimento comunitário, sobretudo em regiões marcadas por uma mobilidade de ocupação, como a Sudeste e Sul.

Se tomarmos a época como de construção das imagens da nação, há nessa série um gesto de mapear os tipos sociais no trabalho, na sua maneira de viver, trabalhar, se alimentar e transformar as paisagens. $O$ conhecimento do território humanizado, da etnologia, da natureza psicológica dos tipos, da mistura de raças, da ligação tipo e lugar, enfim, da territorialização das identidades que compõem o conjunto de regiões da nação, explica a série, dentro da linha descritiva vidaliana: "solo-cultura-ocupação dos lugares-habitações-traços psicológicos"27.

Em geografia regional, estudavam-se tradicionalmente as partes e o todo. Nos mapas que dividem as cinco partes do livro, destaca-se cada região com algumas de suas cenas características, mostrando-a como parte do mapa do Brasil, em pequena dimensão no seu lado esquerdo, e assim por diante para as outras quatro regiões (Nordeste, Centro-Oeste, Leste e Sul) ao longo do livro, que tem 443 páginas na edição traduzida para o francês de 1957, usada nesta análise (Figuras 2 e 3 ). 
Depois do mapa sem fronteiras da capa que reúne algumas cenasminiaturas que compõem o país, as especificidades dos tipos e aspectos de cada região formam o todo do livro. Declara-se querer "apresentar em cada quadro regional [penso na noção do tableau de Vidal de la Blache] as paisagens as mais características e as atividades dos homens, numa visão de conjunto do Brasil". Na nota explicativa dessa edição lê-se ainda sobre o conteúdo: trata de "miniaturas da realidade para os que se interessam por assuntos relacionados com a terra brasileira e a gente que a povoa". A idéia de miniatura é a de um resumo da nação, da história local como ilustração da história nacional ${ }^{28}$.

Tudo isso nos remete aos princípios do discurso vidaliano sobre a caracterização do meio, da vegetação, da unidade entre a região e o clima, do homem e seu rincão; na descoberta dos lugares-tipo (pays-type), como havia observado Vidal de la Blache para a França, lemos nos Tipos e aspectos a insistência sobre os caracteres físicos dominantes, com a descrição minuciosa do quadro paisagístico desenhado com detalhes. É a célebre questão da diversidade e da variedade que está em jogo, do genius loci, de uma organização espacial dos contrastes típicos ao território do País (entendido aqui como nação). As figuras paisagísticas de cada região respondem a uma territorialidade marcada pela alteridade de seus elementos naturais e por seus habitantes que os modificam ou se adaptam a eles. Aparece aí uma noção de base da escola francesa de

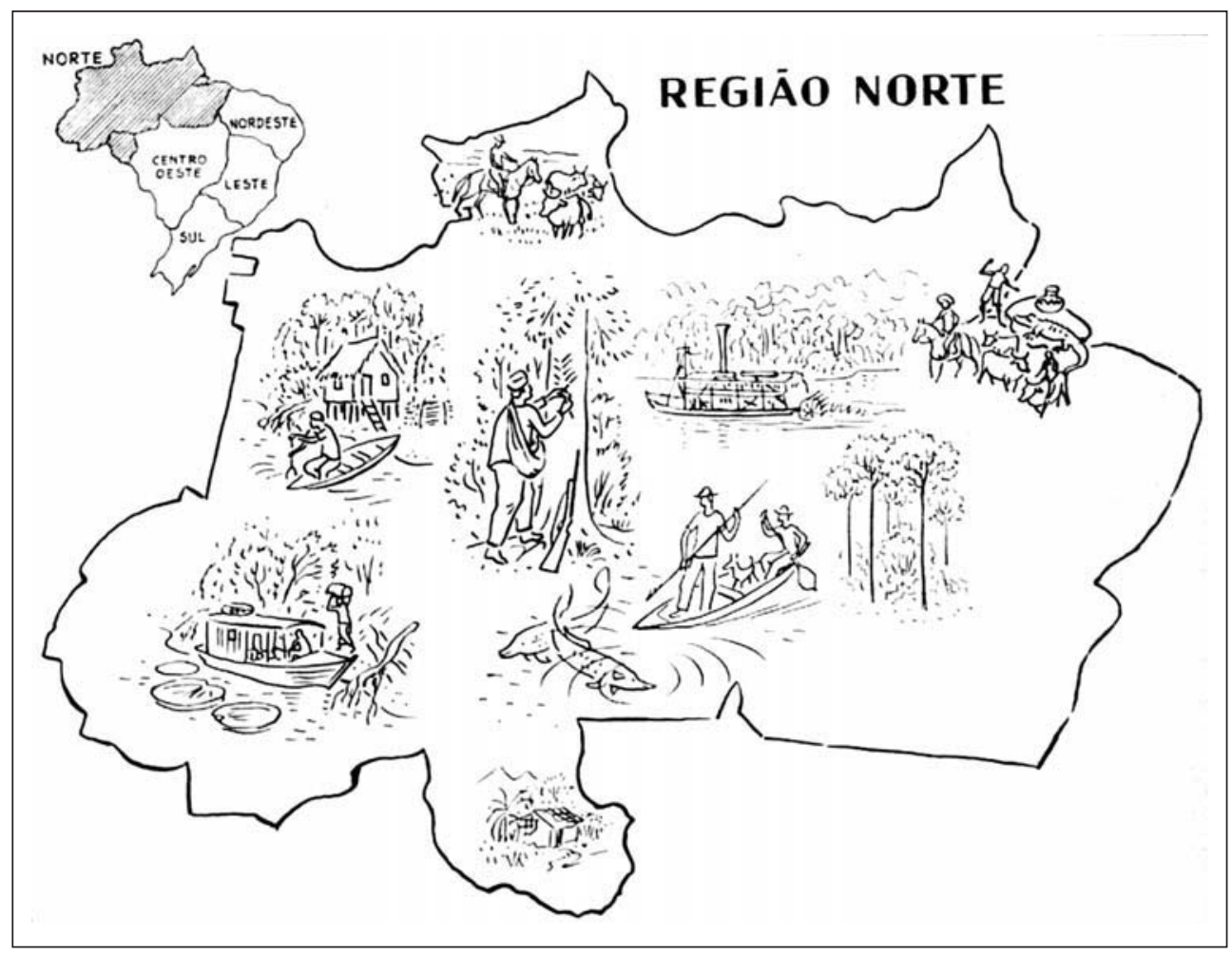

Figura 2 - Mapa da região Norte, Tipos e aspectos do Brasil. Acervo da biblioteca do Instituto de Estudos Brasileiros da Universidade de São Paulo. banos os "mendigos são raros no Brasil". Comenta "paradoxos e contrastes" na relação "cidade/natureza" e "cidades mortas/cidades novas", $\mathrm{e}$ que um "americanismo progressivo vai se associando a uma vida de tradição". Percebe, a exemplo de historiadores que estudaram fora e que publicavam então obras que marcariam a visão crítica do Brasil (penso em Sérgio Buarque de Holanda) que o país mudaria em breve dado à "urbanização rápida" e "industrialização acelerada", expressões de GARCIA, 2000. Ver, mais adiante, considerações sobre a ausência da cidade e dos citadinos nos Tipos e aspectos.

26. MIRANDA, 1938, p. 280. Tradução da autora deste artigo.

27. Cf. GUIOMAR, 1986 , p. 582 .

28. Cf. THIESSE, 1997, p 59. 

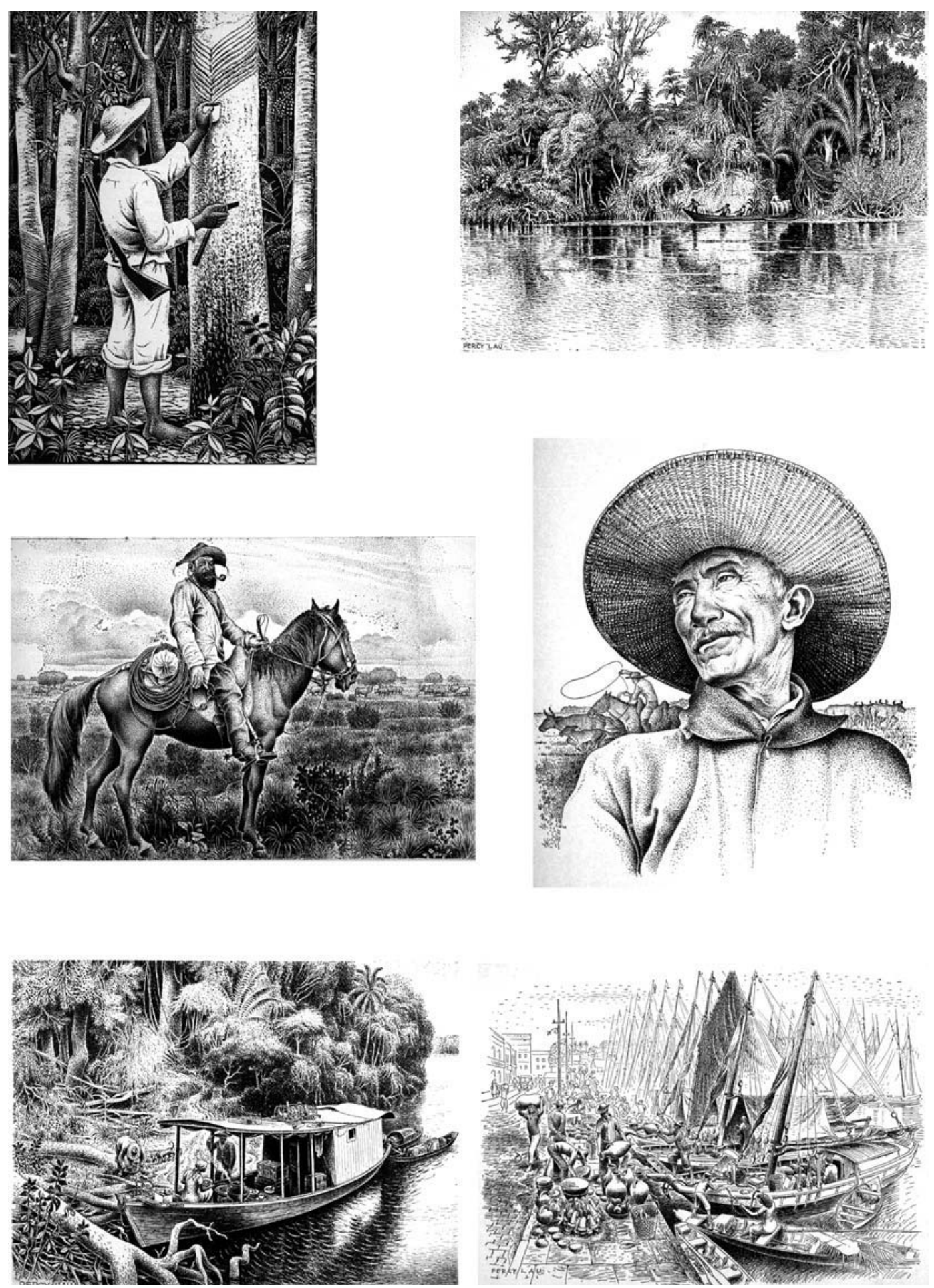

Figura 3 - Prancha composta livremente pela autora reunindo alguns dos tipos e paisagens da Região Norte desenhados por Percy Lau, em Tipos e aspectos do Brasil. Acervo da biblioteca do Instituto de Estudos Brasileiros da Universidade de São Paulo. 
geografia, citada várias vezes ao longo dos textos dos episódios, é a de gênero de vida ("fator de diversificação dos espaços culturais"), na afirmação de caracterizar as especificidades do meio e de seus habitantes, de classificar as atividades produtivas e o habitat, e o "horizonte do trabalho" onde o tipo "evolui" (fala-se também de "regime de trabalho"); essas noções conforme o texto que as explica significam "formas de civilização decorrentes da cooperação da natureza e do homem". E, particularmente, são descritas vestimentas e traços psicológicos exaltando-se a brasilidade dos tipos, a essencialidade da nação. Voltarei com exemplos mais adiante.

O desenho do vaqueiro do Rio Branco e a fotografia deste por Georges Huebner, de 1904 (Figuras 4 e 5), correspondem à observação do prefácio indicando que algumas composições tomam fotos e desenhos por base. Uma das intenções deste estudo sobre visões iconográficas do país e seus códigos é aproximar as representações similares, estudar as modalidades de reiteração figurativa, detectar matrizes ou imagens paradigmáticas - por isso, na busca das convenções iconográficas, introduzo algumas comparações entre coleções diferentes -, mas neste caso, a sugestão é do próprio texto que referencia sua fonte, ou seja, o desenho reproduz o modelo apresentado na edição de 1906, de $O$ vale do Amazonas, de Jacques Ourique, que usa foto de Georges Huebner (fotógrafo suíço que esteve em Manaus, cujas fotos estão no Museu de Etnografia de Genebra). Estamos diante de uma situação de cópia fiel a um modelo. No episódio dos "Burros de carga", publicado originalmente em outubro de 1940 na $R B G$, lê-se que "o desenho reproduz uma fotografia da obra Brasilien, de Peter Fuss".

Vimos que peculiaridades regiona is que caracterizam o geotipo podem se repetir: o vaqueiro do Marajó serve-se do boi para atravessar regiões inundadas cuja topografia e vegetação são apropriadas à criação. Os bois de sela existem também no Centro-Oeste, mas a paisagem e as razões da prática são de outra ordem (Figuras 6 e 7). Marcel Gautherot, percorrendo a llha Mexiana, fotografa nos anos 1940 séries desses "pitorescos" vaqueiros.

Outra imagem dos tipos e aspectos da região Norte é a dos arpoadores de jacarés (Figura 8) também retomada por Gautherot (Figuras 9a a 9f); desconhece-se o uso dessa série feita por ele, que parece se inscrever nas encomendas próprias ao fotojornalismo, em voga na época.

Um ponto que merece ser observado entre as duas edições, a brasileira de 1956 e a francesa que a segue é a presença de diferenças na organização dos "tipos e aspectos" por região; se a edição brasileira simplesmente os colocou em ordem alfabética, na francesa há uma lógica que associa, por exemplo, o tipo ao aspecto, no caso o vaqueiro à caatinga, a paisagem do Nordeste (Figuras 10 e 11). No texto, lemos que ambos "se compreendem, se completam e formam, numa associação fantástica, um só corpo impregnado de estoicismo e de brasilidade". Afinal se "o meio imprime um traço de indiscutível personalidade à paisagem cultural" (conforme lê-se no episódio do vaqueiro do Rio Branco), 


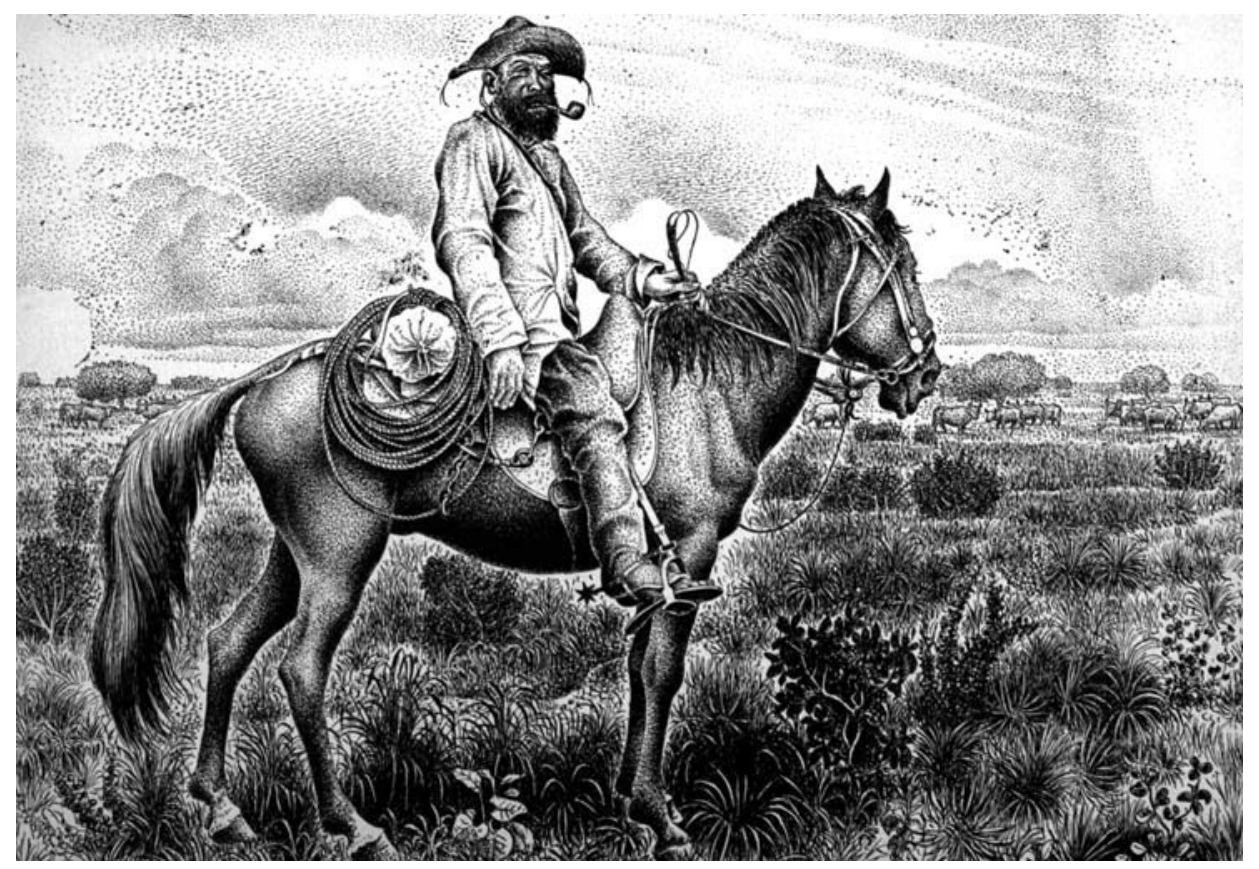

Figura 4 - Vaqueiro do Rio Branco, desenho de Percy Lau para Tipos e aspectos do Brasil. Acervo da biblioteca do Instituto de Estudos Brasileiros da Universidade de São Paulo.

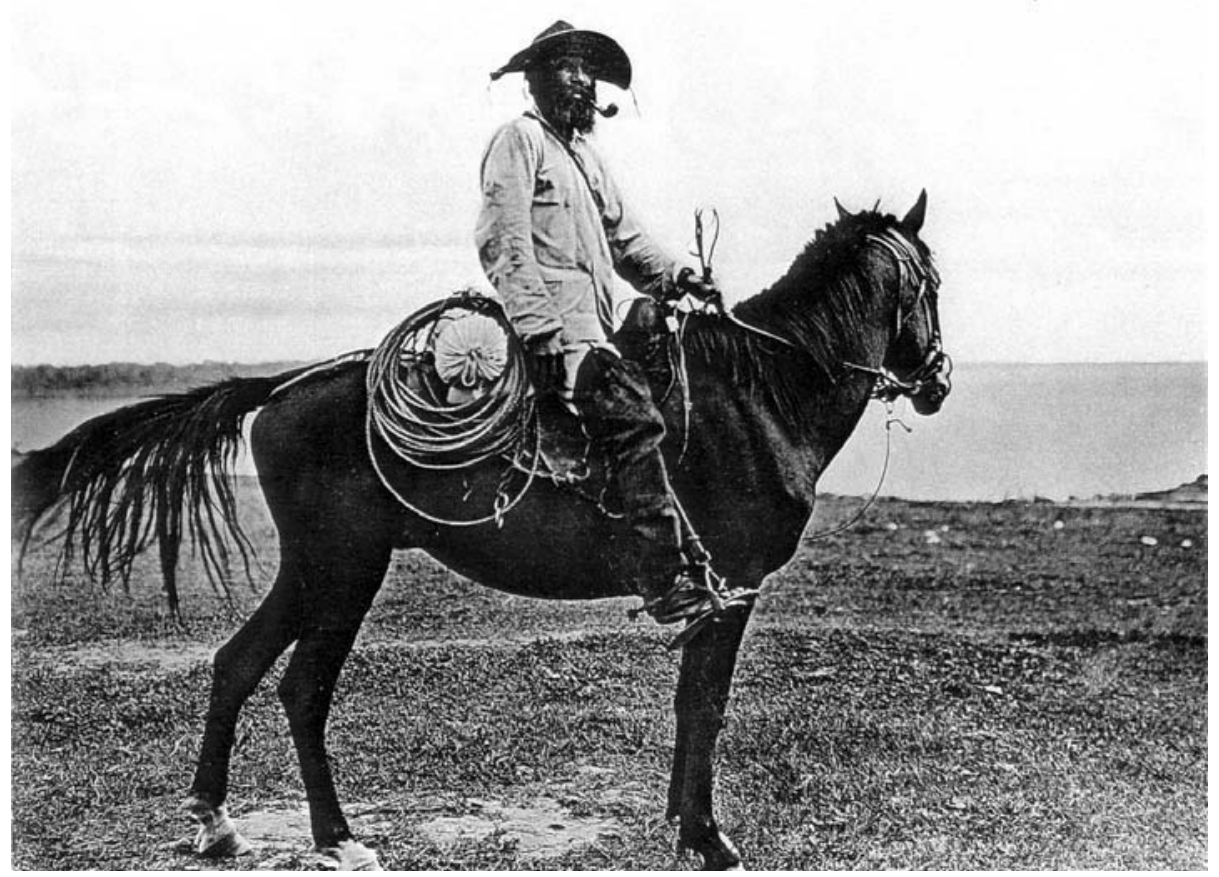

Figura 5 - Vaqueiro do Rio Branco, fotografia de George Huebner em Jacques Ourique, O Vale do Amazonas, 1906, republicada em Daniel Schepf et al., George Huebner. Un photographe à Manaus, Genebra, Musée d’ethnographie, 2000. 


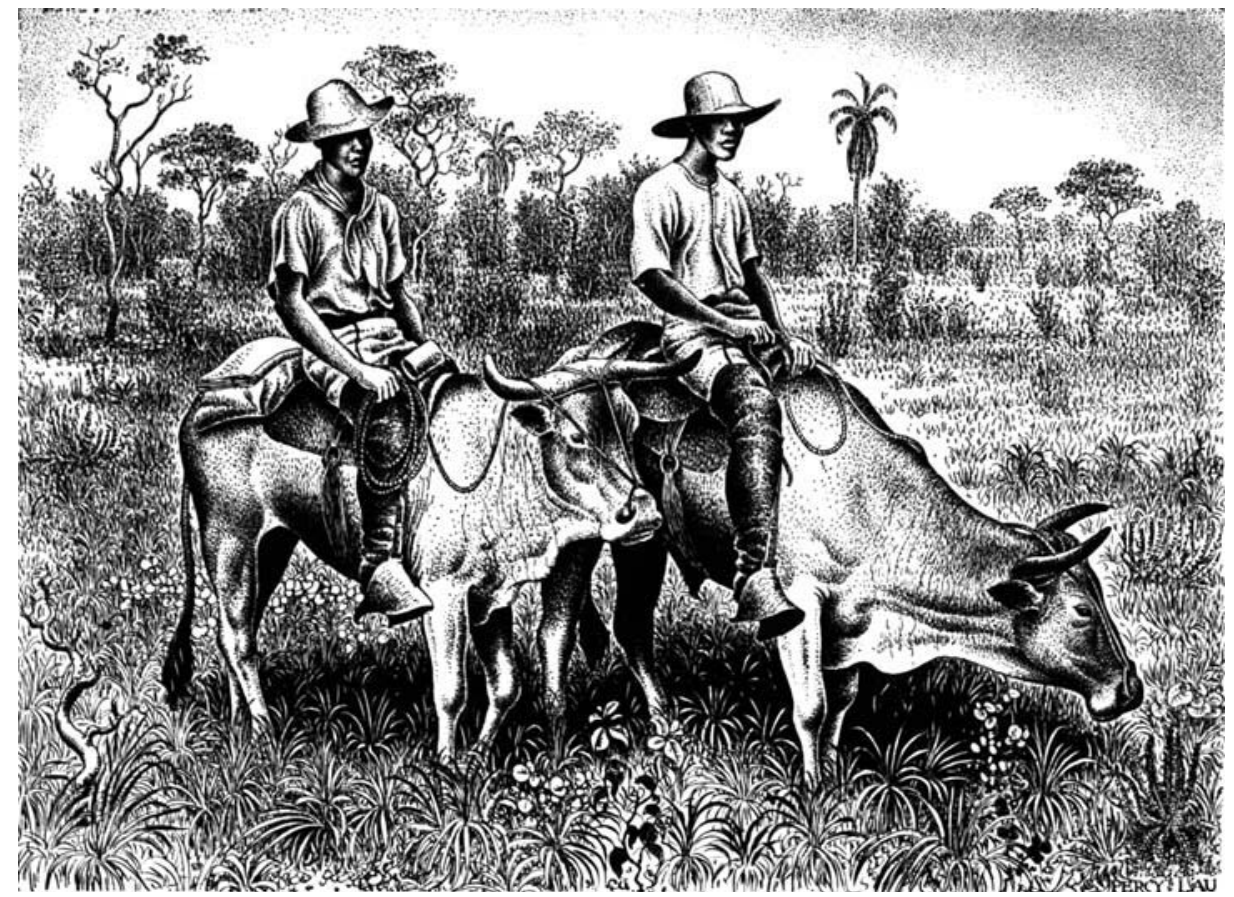

Figura 6 - Bois de sela, desenho de Percy Lau para Tipos e aspectos do Brasil. Acervo da biblioteca do Instituto de Estudos Brasileiros da Universidade de São Paulo.

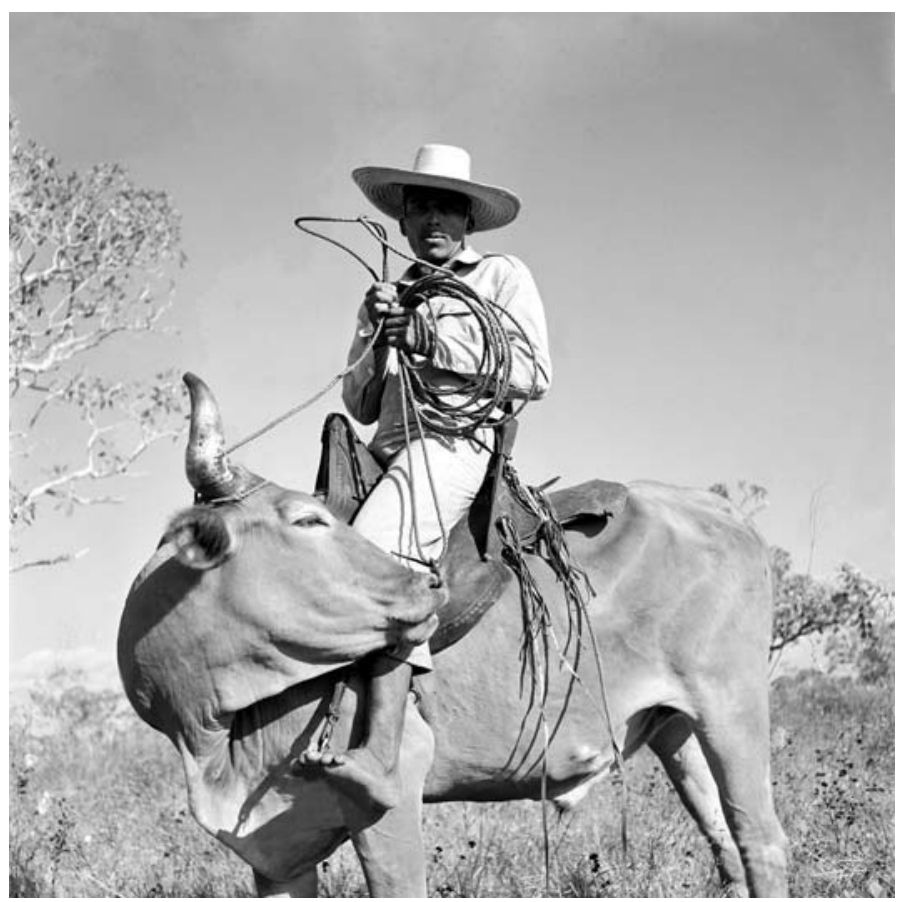

Figura 7 - Vaqueiro, Iha Mexiana/PA, c. 1943. Fotografia de Marcel Gautherot. Acervo do Instituto Moreira Salles. 


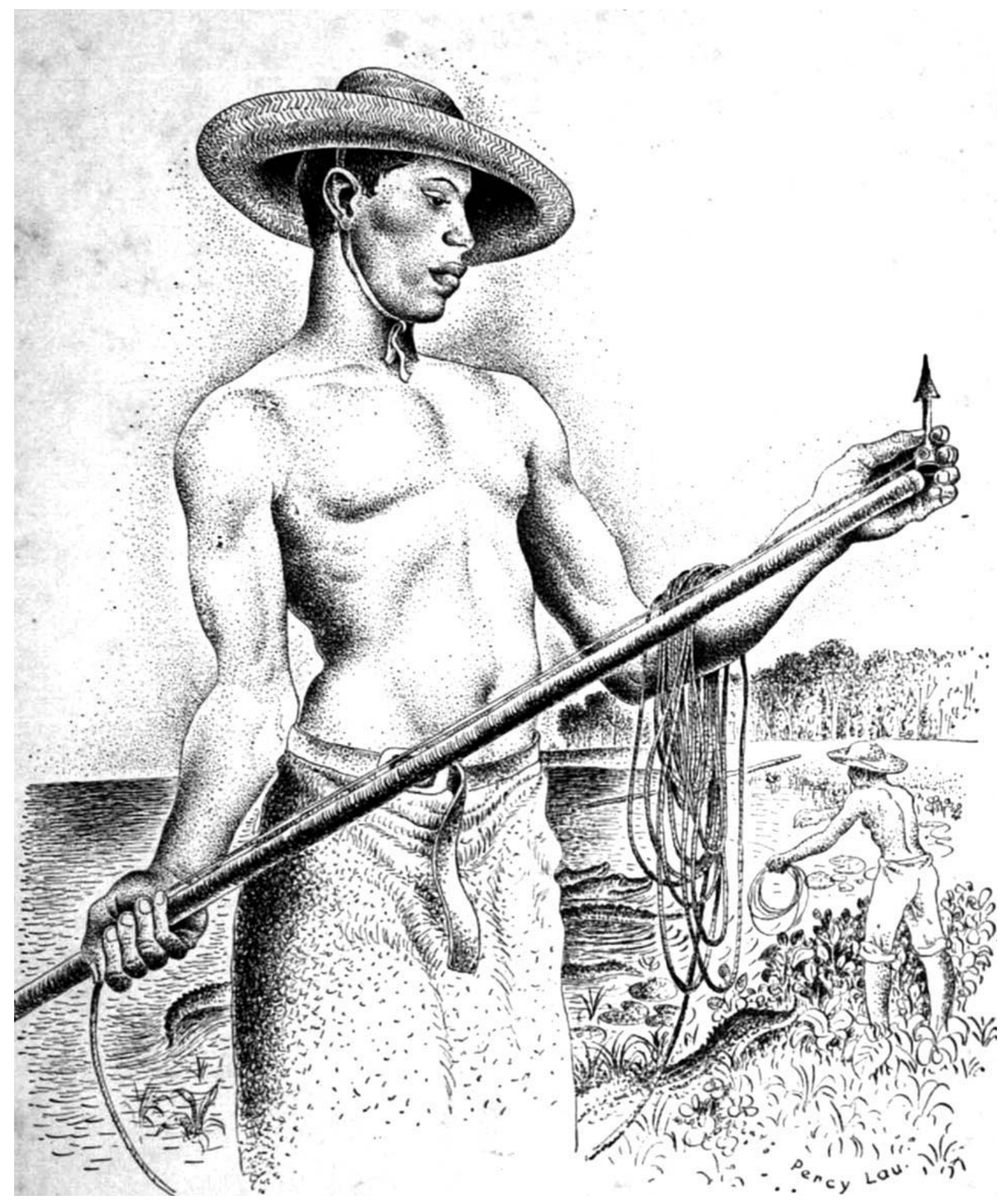

Figura 8 - Arpoadores de jacaré, desenho de Percy Lau para Tipos e aspectos do Brasil. Acervo da biblioteca do Instituto de Estudos Brasileiros da Universidade de São Paulo. 

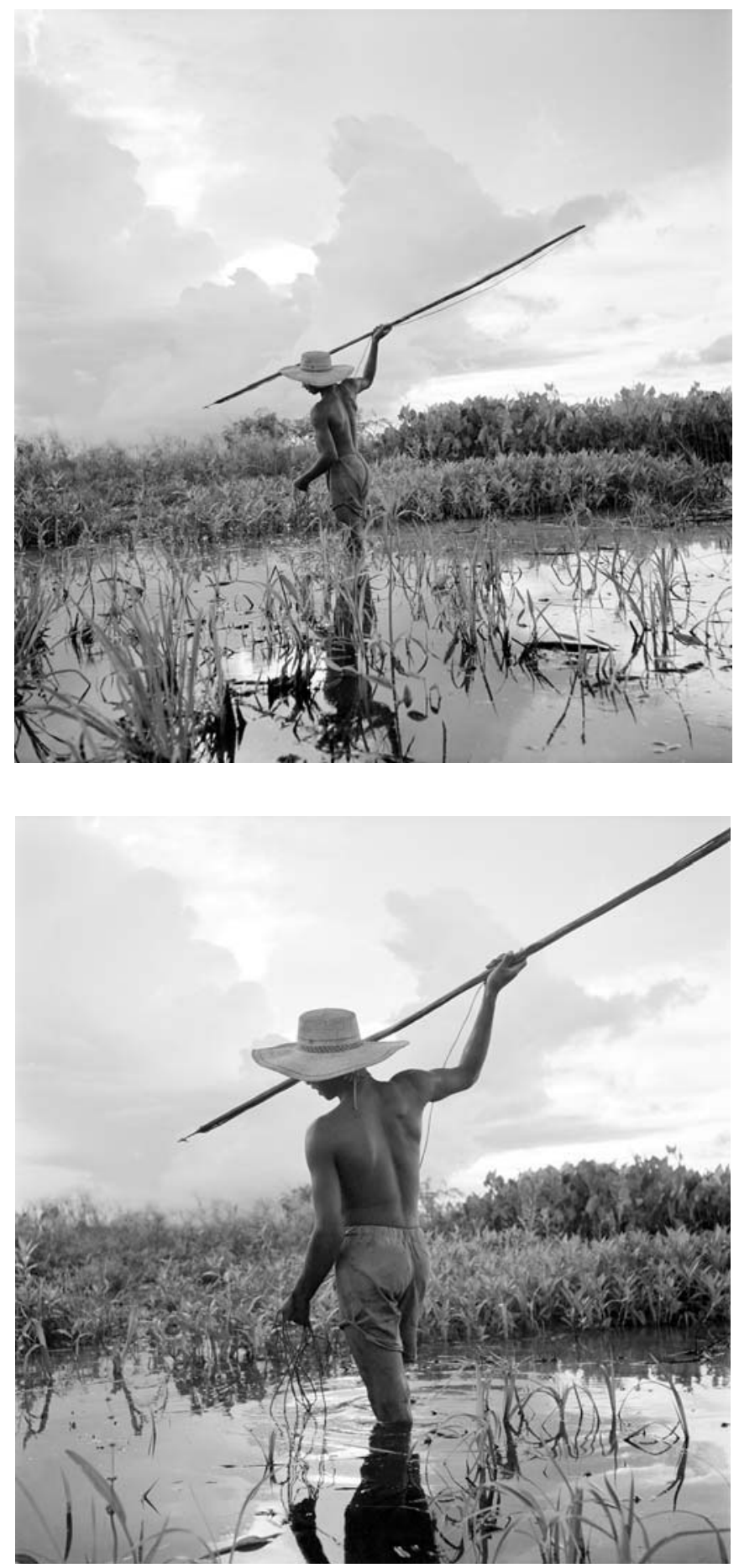

Figuras 9a a 9f - Série da caça ao jacaré, Ilha Mexiana/PA, c. 1943. As séries do arquivo pessoal de Marcel Gautherot, organizadas por ele em pranchas-contato, apresentam ora movimentos de aproximação contínua, ora um travelling documentário da ação na multiplicidade de pontos de vista e momentos variados em que domina a idéia de seqüência ou de encadeamento instantâneo. Fotografias de Marcel Gautherot. Acervo do Instituto Moreira Salles. 

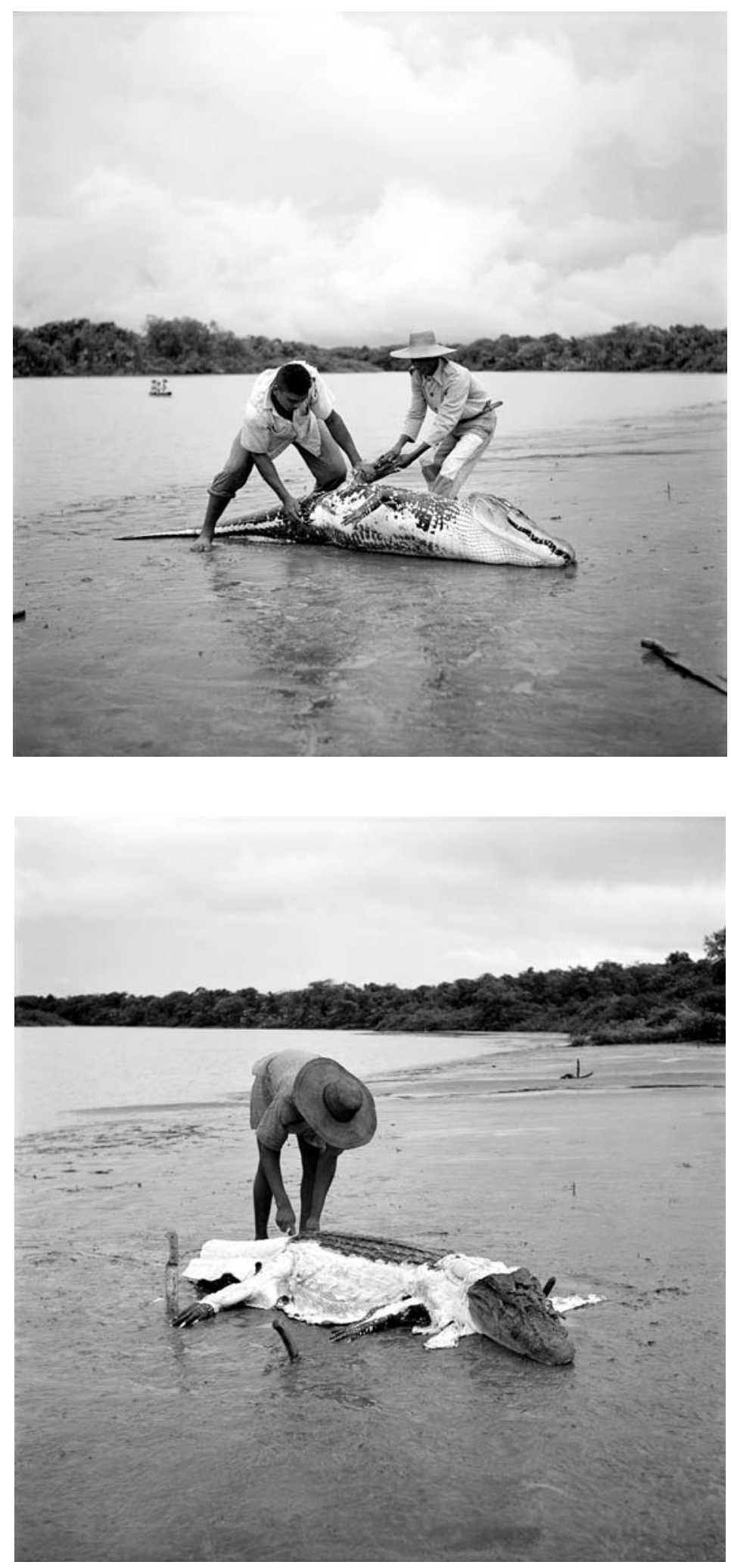

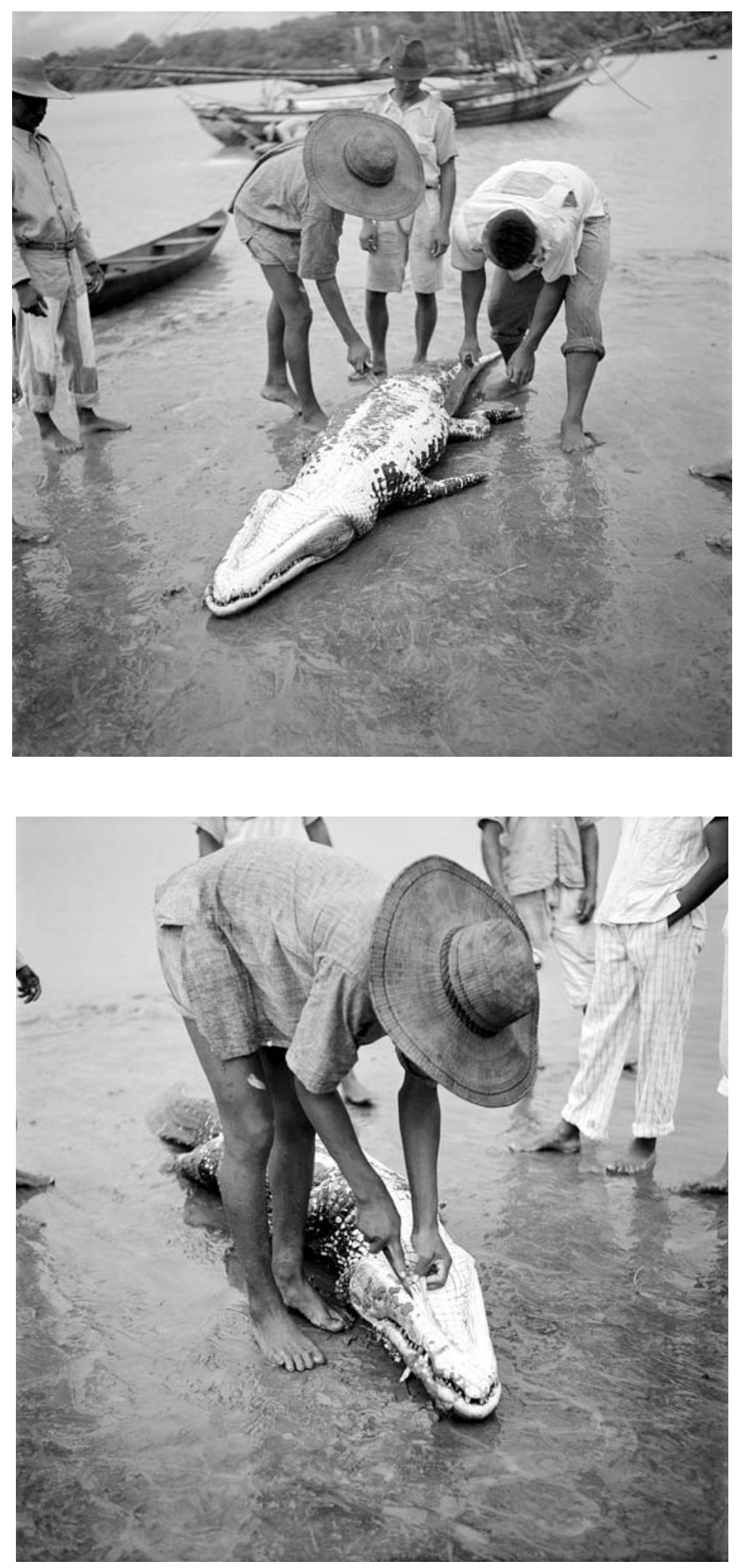

Annals of Museu Paulista.v. 13. n.2. Jul.- Dec. 2005. 


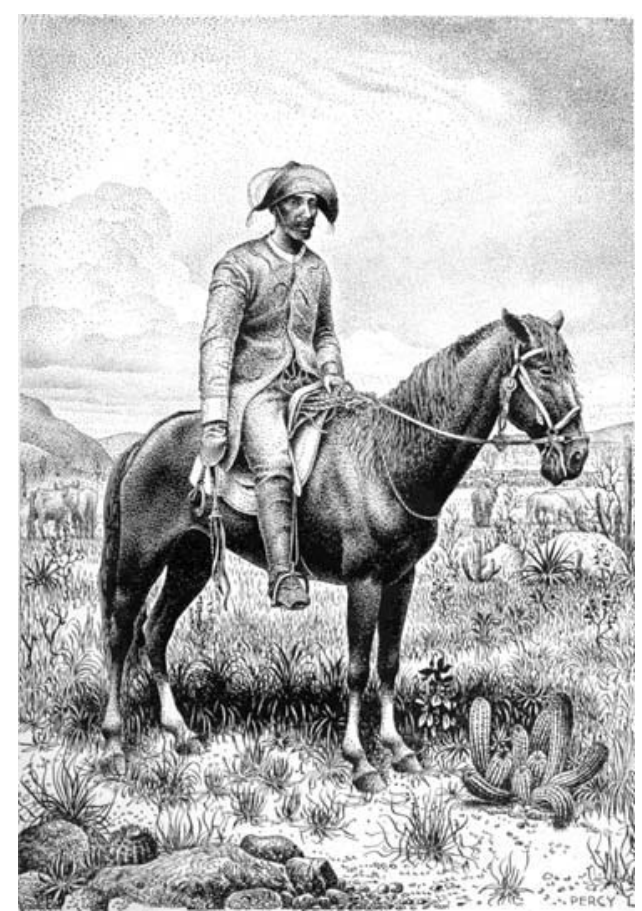

Figura 10 - Vaqueiro do Nordeste, desenho de Percy Lau para Tipos e aspectos do Brasil. Acervo da biblioteca do Instituto de Estudos Brasileiros da Universidade de São Paulo.

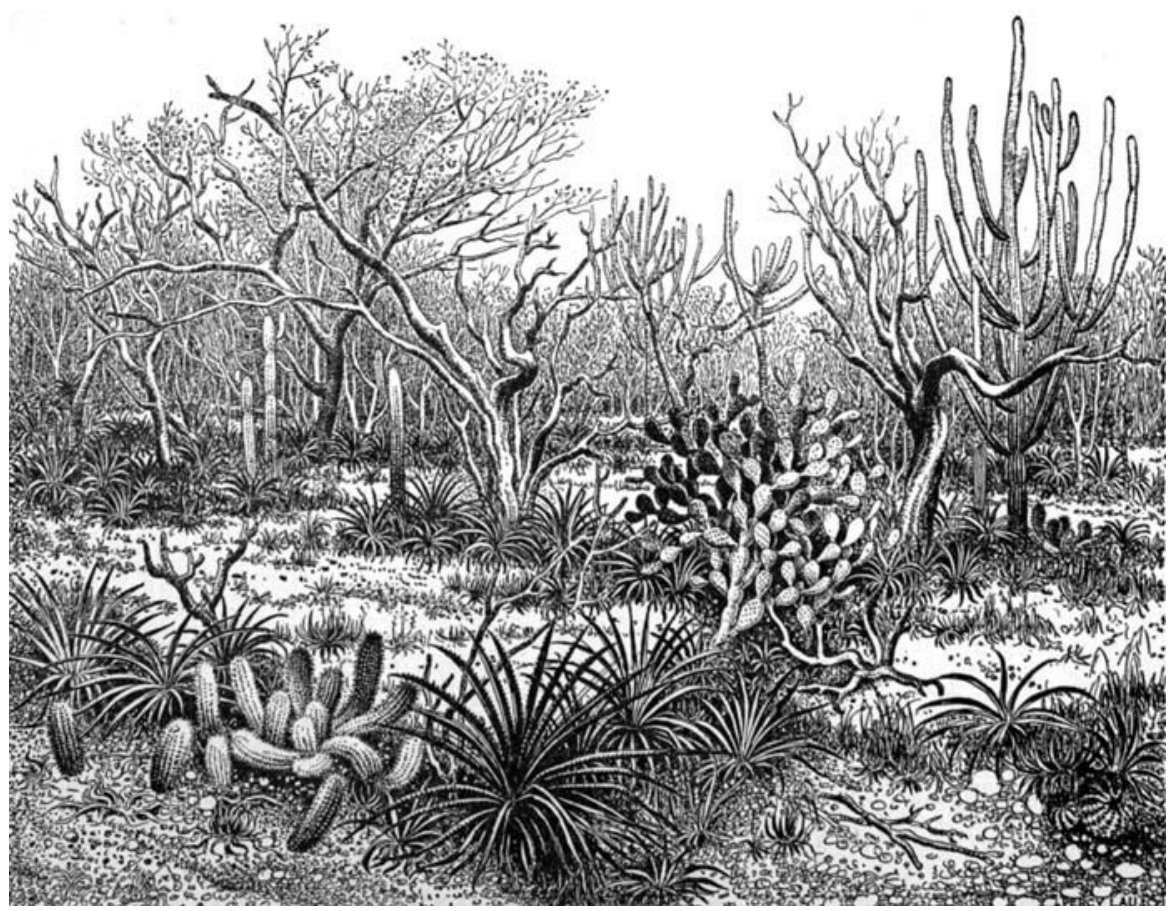

Figura 11 - Caatinga, desenho de Percy Lau para Tipos e aspectos do Brasil. Acervo da biblioteca do Instituto de Estudos Brasileiros da Universidade de São Paulo. 


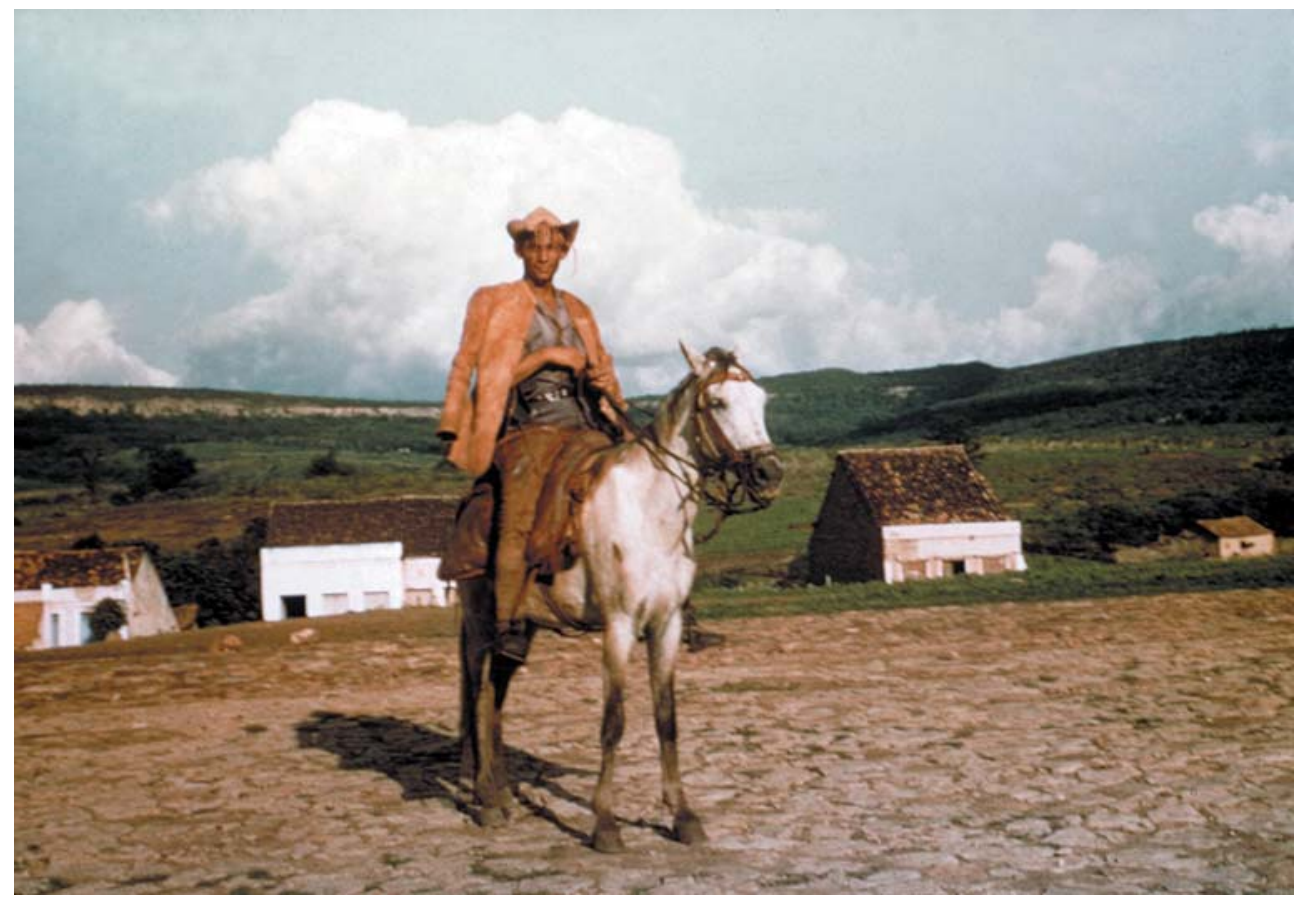

Figura 12 - Vaqueiro na praça de vilarejo, 1944. Fotografia de Pierre Monbeig. Copyright PRODIG/ CNRS, Paris.

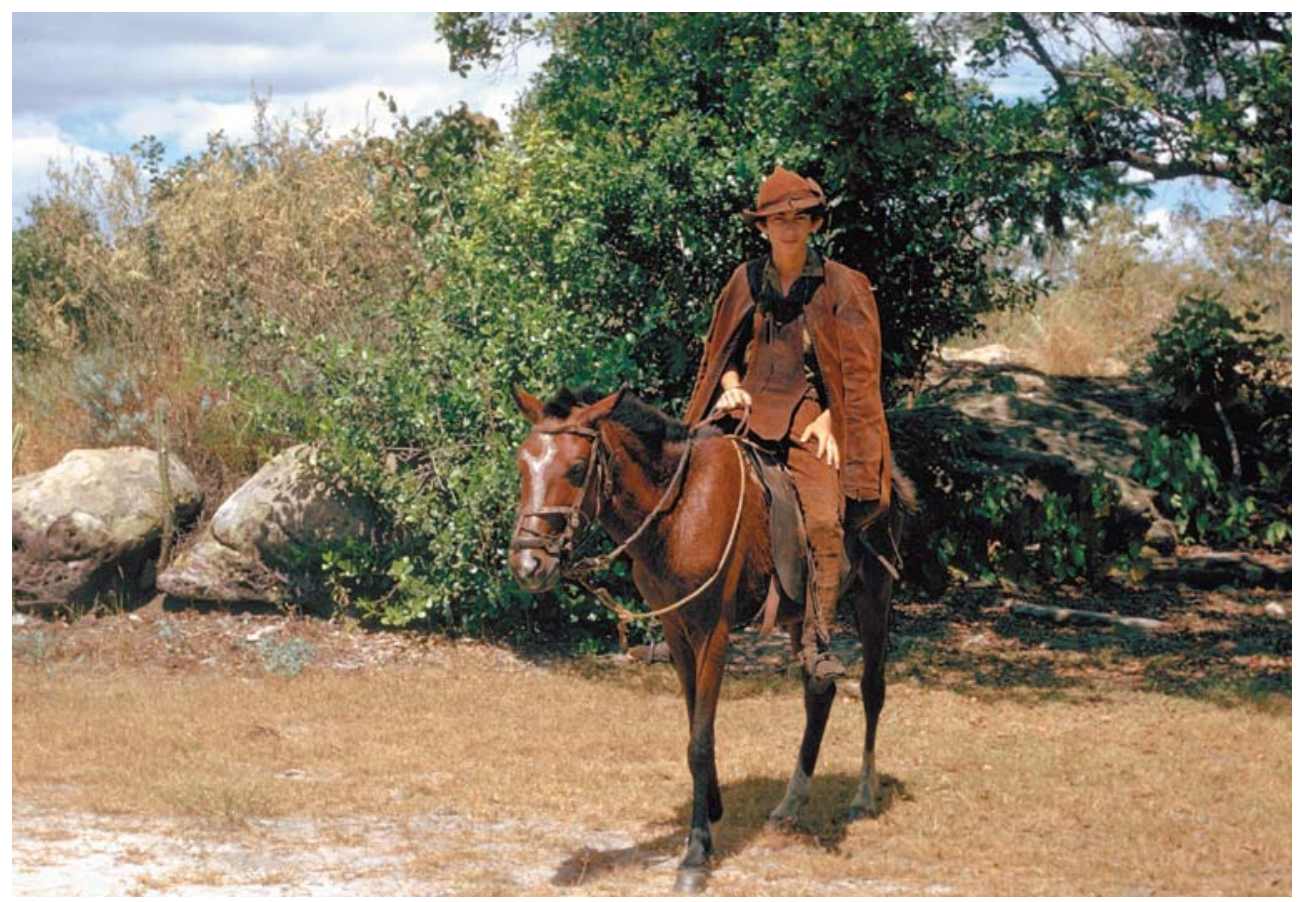

Figura 13 - Vaqueiro, 1971. Fotografia de Pierre Monbeig. Copyright PRODIG/ CNRS, Paris. 
29. TIPOS E ASPECTOS, 1956, p. 169-170. Confere com a descrição de CUNHA, 2001, p. 213

30. Cf. CLAVAL, 1998, p. 201ss. Os livros da coleção de Deffontaines apresentam uma iconografia muito próxima da dos $T i$ pos e aspectos, com desenhos de ilustradores profissionais; na França, coleções do gênero "tipos e costumes" que vou mencionar mais adiante vão até os anos 1950 . essa associação que se procura seguir em vários episódios da edição francesa é a melhor forma de organizá-los. Passo sobre os estereótipos presentes na descrição, para destacar a parte em que o vaqueiro é visto como um heróiguerreiro, convocando-se a representação literária do épico de Euclides da Cunha:

As vestes são uma armadura. Envolto no gibão de couro curtido, de bode ou de vaqueta; apertado no colete, também de couro; calçando as perneiras, de couro curtido ainda, muito justas, cosidas às pernas e subindo até as virilhas, articuladas em joelheiras de sola; e resguardados os pés e as mãos pelas luvas e guarda-pés de pele de veado - é como a forma grosseira de um campeador medieval desgarrado em nosso tempo. Essa armadura, porém de um vermelho pardo, como se fosse de bronze flexível, não tem cintilações, não rebrilha ferida pelo sol. É fosca e poenta. Envolve ao combatente de uma batalha sem vitórias... ${ }^{29}$

Dos diapositivos coloridos de Pierre Monbeig feitos no Brasil, os mais antigos são de 1944, entre os quais encontramos também o vaqueiro do Nordeste correspondendo a essa representação, que 30 anos depois permanecerá praticamente a mesma (Figuras 12 e 13).

Ao longo da descrição dos tipos há um esforço de legitimação, de fixação da realidade viva, de reconhecimento das identidades regionalizadas na dureza do trabalho e precariedade do meio ambiente. Vidal de la Blache é citado na referência ao homem como "agente geográfico" e suas "invenções", para não dizer inventividades - nos "meios ingratos" (lembremo-nos que no seu Tableau de la géographie de la France, "I'environnement plaisant n'est qu'une illusion"; de fato, o meio ambiente é raramente aprazível e agradável como vimos na descrição da caatinga). Os tipos estão flagrados não raro num "combate", numa confrontação com a natureza, como na coleção que Pierre Deffontaines havia feito para a editora Gallimard, L'homme et la terre. Observese que os Tipos e aspectos seguem a linha vidaliana revista por Brunhes e retomada por Deffontaines, próprias à geografia cultural francesa-o homem na paisagem, sua "batalha contra a natureza hostil" ou as formas de "colaboração harmoniosa" com ela - na coleção dirigida por Deffontaines evocam-se gêneros de vida, meio, plantas, animais, produtos, composição étnica ${ }^{30}$.

Nas edições dos Tipos e aspectos não há bibliografia no fim da obra, nem notas de rodapé, porém, ao longo do texto, em maiúsculas, encontramos as referências - sejam clássicos da história do Brasil desde o século XVI, sejam obras contemporâneas à série (mencionei o desenvolvimento do mercado editorial brasileiro, a partir dos anos trinta, sobre o qual existem inúmeros trabalhos). São citados desde tratados e obras da historiografia a simples brochuras de fitogeografia, mineralogia, biologia, etc. - para mencionar apenas os nomes mais conhecidos da escola francesa de geografia: Paul Vidal de la Blache, Jean Brunhes, Albert Demangeon, Pierre Deffontaines; outras referências reúnem testemunhos dos que viveram ou passaram pelo Brasil, como Humboldt, aos brasileiros romancistas, engenheiros, jornalistas, funcionários de instituições federais (agrônomos, técnicos e militares) - a esses textos juntam-se ainda contos populares e lendas locais. Nessas referências várias correntes se misturam, acadêmicas ou 
não, inscritas na curiosidade e redescoberta narrada do país, no inventário da diversidade de uma população e seu território. Vimos a convocação de épico do começo do século XX, Os sertões, romance regionalista avant la lettre que funcionou para a geração dos anos 1930/1940 como um "mito de origem para o Brasil refazer sua raízes voltando-se para o interior do país"

Um ponto a observar é que as representações se referem sobretudo à realidade rural - as cidades e a arquitetura praticamente não aparecem entre os "aspectos", salvo de maneira discreta - vê-se apenas alguns vilarejos quando são mostradas as habitações rústicas, os mocambos do Nordeste (Figura 14), lembrando o ensaio de Gilberto Freyre, vistos como um "problema étnico-cultural complicado pelo pauperismo e pela concentração urbana". Sabemos da importância do habitat rural na geografia cultural francesa e também nos textos do Congresso do Folclore e Exposição de Paris, em 1937, comentados acima. Há também a representação das "aglomerações populares" ou favelas do Rio de Janeiro, objeto de um episódio e cenário para as lavadeiras, tipo comum da geografia humana (trata-se do único desenho em que aparecem edifícios (Figuras 15 e 16). $\bigcirc$ elemento feminino está presente muitas vezes nos Tipos e aspectos, é o caso das negras da Bahia, que, como na imagem das lavadeiras, apresenta também a cidade como pano de fundo (Figura 17). Notei ainda que na capa modernizada da sétima edição, em 1963, aparece entre as miniaturas da capa a representação de Brasília, na arquitetura do Palácio do Congresso e da Alvorada, que no entanto não entraram no corpo do texto.

Lugares "típicos" das cidades também são "aspectos" a inventariar regionalmente. É o caso dos mercados, especialmente os das beiras de porto, outro cenário de eleição da geografia humana e dos fotógrafos da época, entre os franceses Verger e Gautherot, embalados pela leitura de Jubiabá, de Jorge Amado. No episódio do mercado Ver-o-Peso, em Belém, um dos lugares da memória do país, há referências sobre a paisagem sonora e à diversidade étnica dos seus personagens (Figura 18). Se Monbeig enfocou sobretudo o "pitoresco" da feira artesanal, os pavilhões de ferro e o casario urbano das imediações, Gautherot ateve-se a seqüências de imagens da trama das velas, mastros e cordas das embarcações na beira-rio e no porto-mercado, das pedras de gelo e das cargas, captando também a cidade velha como fundo de algumas tomadas (Figura 19); movimentado-se entre os trabalhadores e pescadores, Gautherot sobe nos mastros para fotografar do alto os barcos, principal protagonista das séries de suas pranchas-contato sobre o Ver-o-Peso.

De um lado, há o Estado que busca modernizar a sociedade por uma série de medidas e as cidades que se industrializam, de outro, um Brasil profundo - é desse Brasil que tratam os tipos e aspectos na descrição da distribuição interior do habitat, dos utensílios, da rusticidade dos homens do mundo rural; não se tem mais vergonha, como no século XIX, de parecer "atrasado", de "estar longe da civilização", ao contrário. As representações do país mudam em relação às do século anterior - não é mais a hagiografia dos grandes homens, os fatos políticos, a busca de traços urbanos de cosmopolitismo que contam. No naturalismo que define os tipos nacionais, não se trata de geopolítica, mas de
31.GARCIA, op.cit.,p.32. $\mathrm{O}$ enfoque cultural do brasilianismo das paisagens e dos homens, da busca de unidade nacional, insere-se nessa chave do regionalismo literário, cujas relações com a iconografia seria um tema fundamental a aprofundar no Brasil. Já citamos o livro de Anne Marie Thiesse relativo ao caso francês; entre as análises recentes das representações das paisagens nacionais européias, ver o livro de WALTER, op. cit. Já para a ligação entre o político e o vernacular, na França, ver FAURE, 1989. 


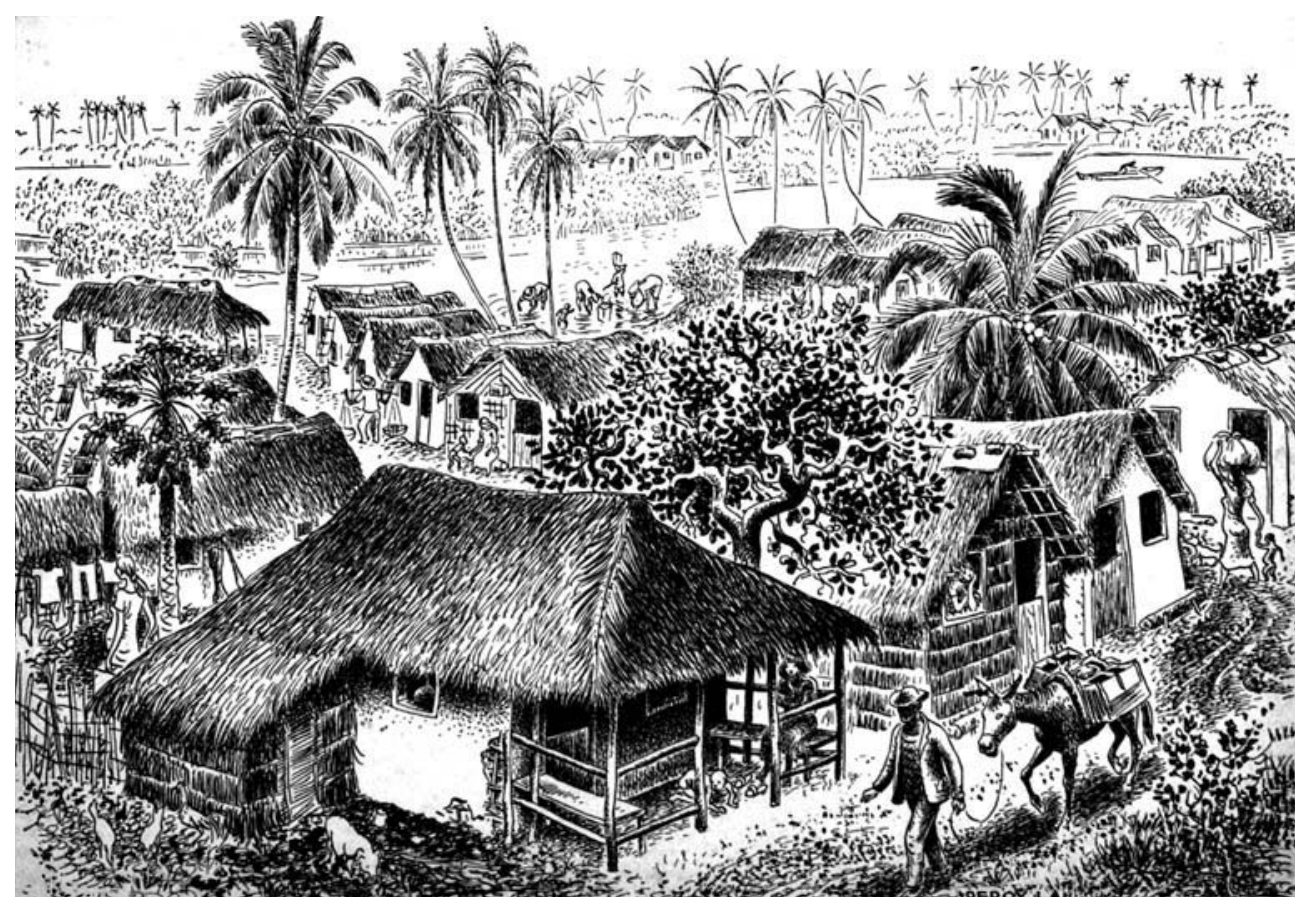

Figura 14 - Mocambos do Nordeste, desenho de Percy Lau para Tipos e aspectos do Brasil. Acervo da biblioteca do Instituto de Estudos Brasileiros da Universidade de São Paulo.

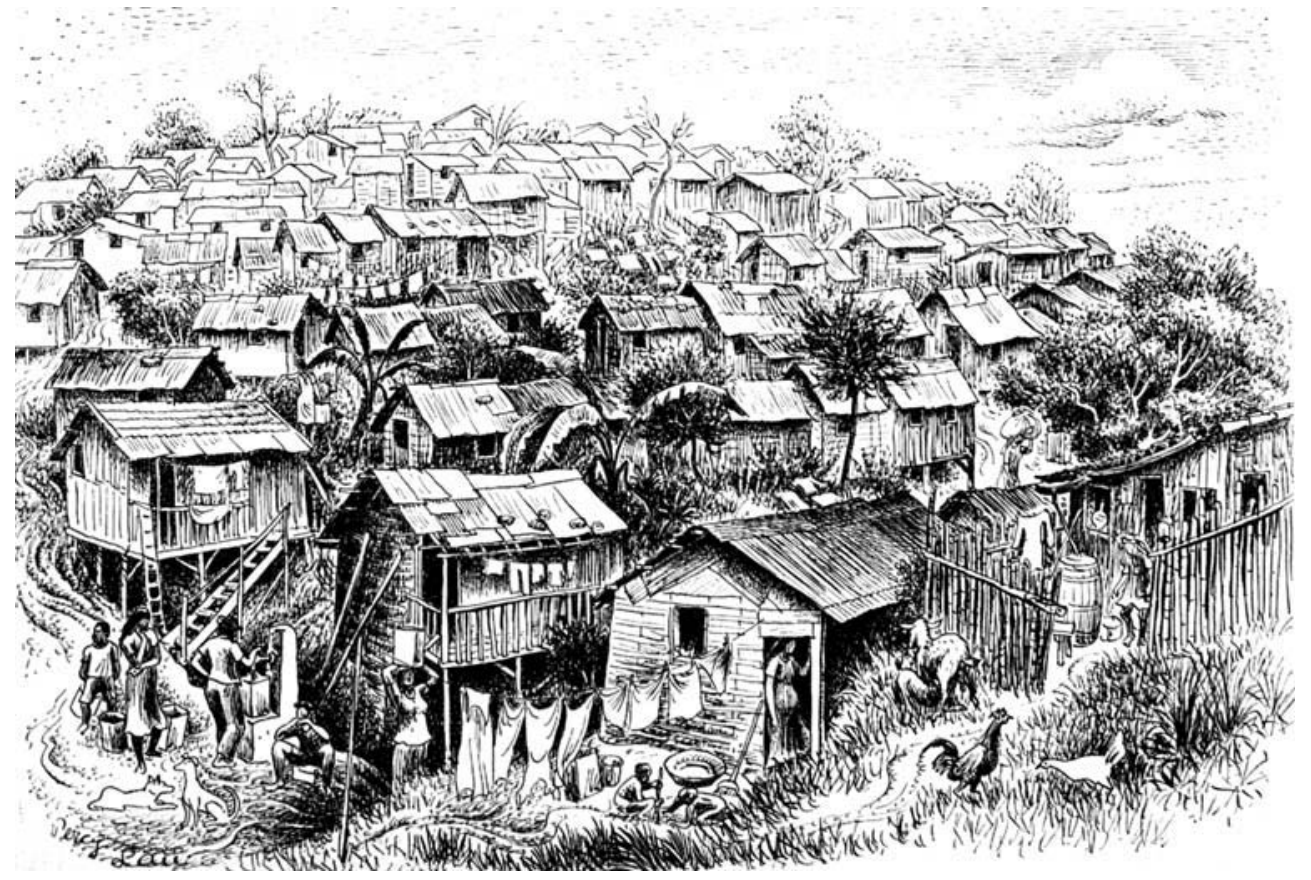

Figura 15 - Favela, desenho de Percy Lau para Tipos e aspectos do Brasil. Acervo da biblioteca do Instituto de Estudos Brasileiros da Universidade de São Paulo. 


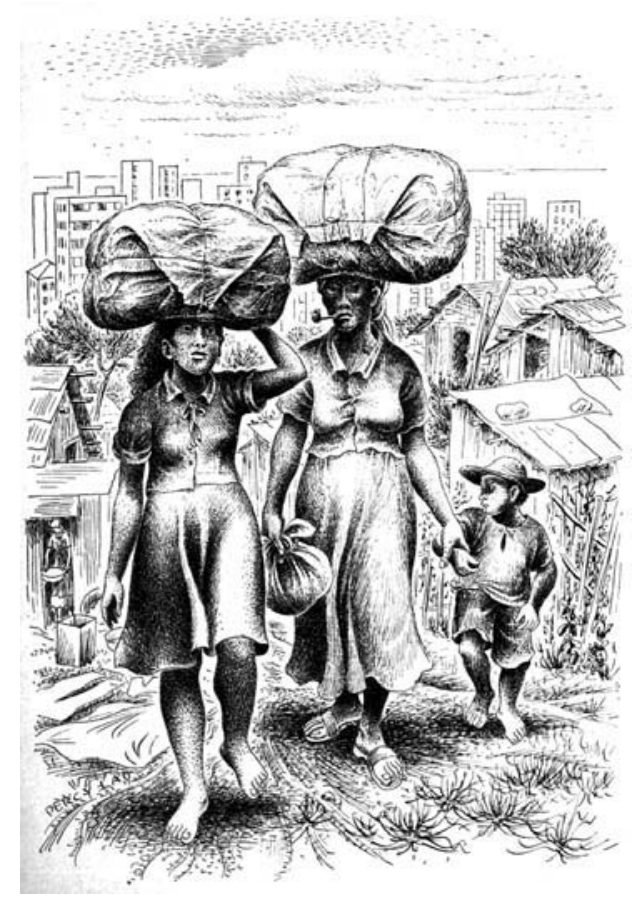

Figura 16 - Lavadeiras, desenho de Percy Lau para Tipos e aspectos do Brasil. Acervo da biblioteca do Instituto de Estudos Brasileiros da Universidade de São Paulo.

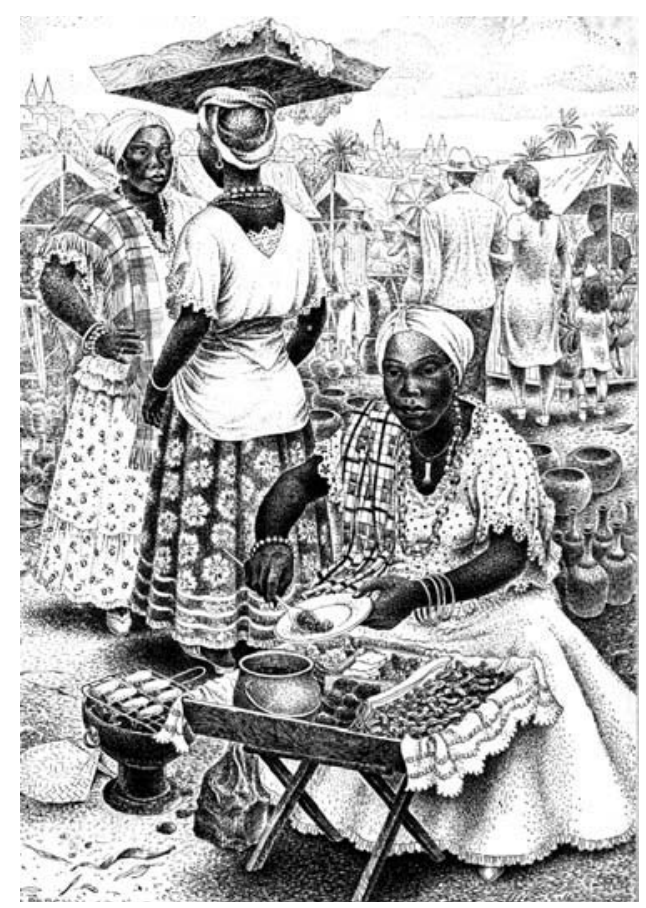

Figura 17 - Negras da Bahia, desenho de Percy Lau para Tipos e aspectos do Brasil. Acervo da biblioteca do Instituto de Estudos Brasileiros da Universidade de São Paulo. 


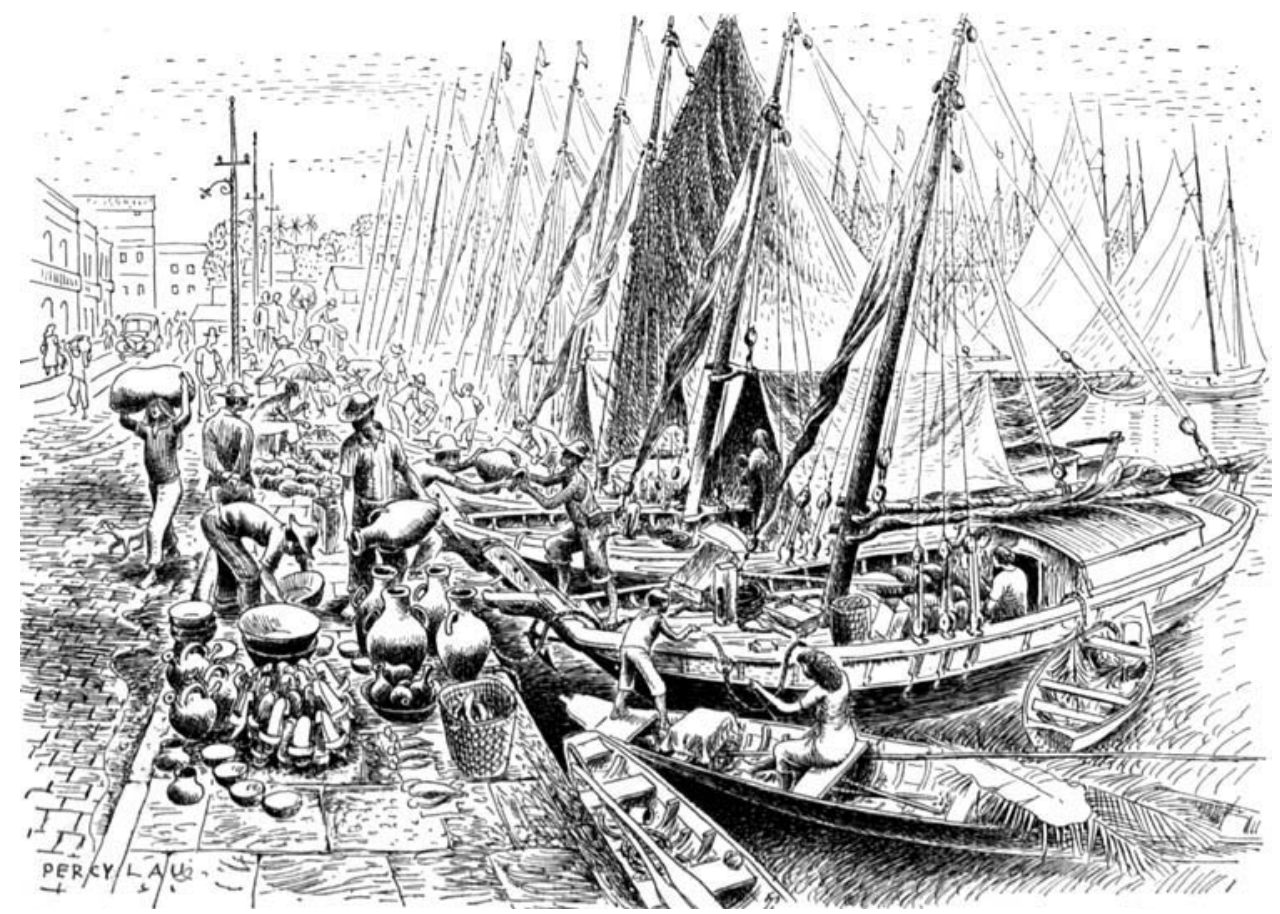

Figura 18 - Mercado Ver-o-Peso, Belém, desenho de Percy Lau para Tipos e aspectos do Brasil. Acervo da biblioteca do Instituto de Estudos Brasileiros da Universidade de São Paulo.

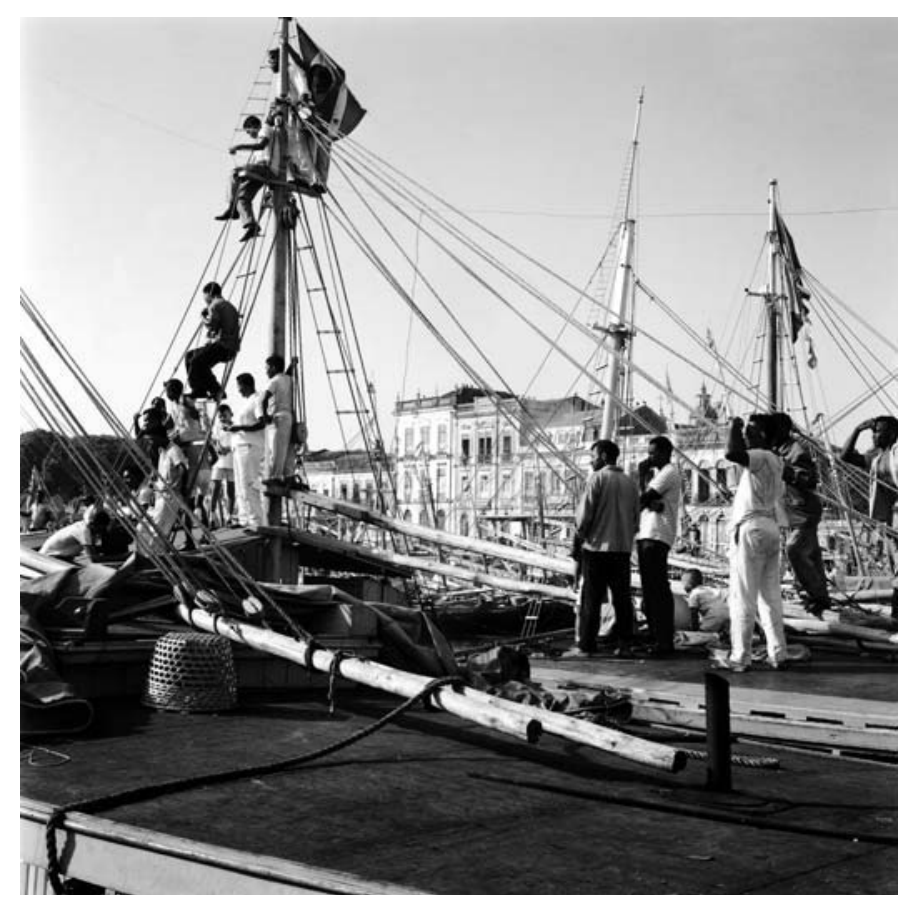

Figura 19 - Mercado Ver-o-Peso, Belém/PA, c. 1954-57. Fotografia de Marcel Gautherot. Acervo do Instituto Moreira Salles. 
geografia humana, uma geografia da vida no seu sentido mais próprio, com enfoques fitogeográfico, biogeográfico, econômico, descrevendo-se as particularidades da relação homem/ambiente/região. Esse tipo de "celebração do mundo rural" não é apanágio do Brasil tampouco. François Walter o analisa como um fenômeno geral na primeira metade do século XX. Nesse particular, é bom lembrar que nos regimes totalitários europeus dos anos trinta, no nacionalsocialismo e na política de Vichy, as referências conservadoras ao solo e aos camponeses é freqüente.

Na caracterização de uma paisagem regional, o papel das plantas é outro ponto de destaque na série. Tomemos um exemplo do Nordeste: o palmeiral de carnaúbas (Figura 20), "árvore da vida, da providência", como escreveu Humboldt destacando as múltiplas utilidades das palmeiras na economia rural. A importância antropogeográfica dos carnaubais é ressaltada: "verdadeiras ilhas humanas em zona devastada pela sêca", conforme expressão de Jean Brunhes, citado no texto, "pelo seu conhecido trabalho La géographie humaine". A individualidade das paisagens culturais é acentuada pelas imagens "fisionômicas" da vegetação. $\bigcirc$ "personagem" reaparece nos diapositivos de Monbeig 30 anos depois (Figura 21), enquanto nas séries de Marcel Gautherot todo o processo de colheita é fotografado, as séries desdobrando-se até o enquadramento em gros plan da folha, em fotografia que lembra ainda os preceitos figurativos da Nouvelle objectivité e as particularidades do trabalho de um artista-fotógrafo muito além do simples registro documental (Figuras 22a a $22 \mathrm{f}$ e 23).

A extração do caroá e as imagens das usinas artesanais do sertão do Nordeste (Figura 24) podem também ser comparadas a outras imagens que registram processos de indústria artesanal semelhante, demonstrando o interesse pelo registro dessa produção classificada entre as "velhas formas de cultura" cujas etapas são descritas minuciosamente no texto; imagens semelhantes de Pierre Verger aparecem no livro de Antoine Bon (Figura 25) e, no acervo fotográfico de Monbeig, a seqüência sobre a colheita e secagem da malva de Santarém (Figura 26) reitera esse tipo de representação até o detalhamento da fibra.

As salinas (Figura 27) constituem uma outra paisagem típica do Nordeste e do Estado do Rio de Janeiro; no episódio são citados livros que se inscrevem nesse período áureo de publicações que cobrem também a cultura material e os produtos do país e que, como em outros episódios, destacam o heroísmo dos trabalhadores: "indústria genuinamente brasileira, é uma dádiva generosa da natureza. $\bigcirc$ sol, a terra, as águas, os ventos, os caboclos fortes, resistentes a tudo, de epiderme queimada e pés e mãos sangrando ao contato dos cristais são os trabalhadores do sal. Gente rara e indomável"32. Marcel Gautherot dedicou às salinas uma de suas mais belas séries fotográficas em que o contraste de luz no preto-e-branco atinge alto domínio técnico, as seqüências narrativas mostrando as paisagens e seus tipos humanos nas diversas fases da produção (Figura 28). As salinas são consideradas como um dos aspectos geográficos mais importantes do país, importância acrescida no texto pela sua ligação histórica à expansão da criação de gado, desde o período colonial quando se destaca o papel dos bandeirantes na "integração das regiões distantes".

Annals of Museu Paulista. v. 13. n.2. Jul.- Dec. 2005.
32.Texto de um entre tantos livros do Serviço de Informação Agrícola, $A$ indústria extrativa do sal, de Dioclécio Duarte, publicado em 1941. 


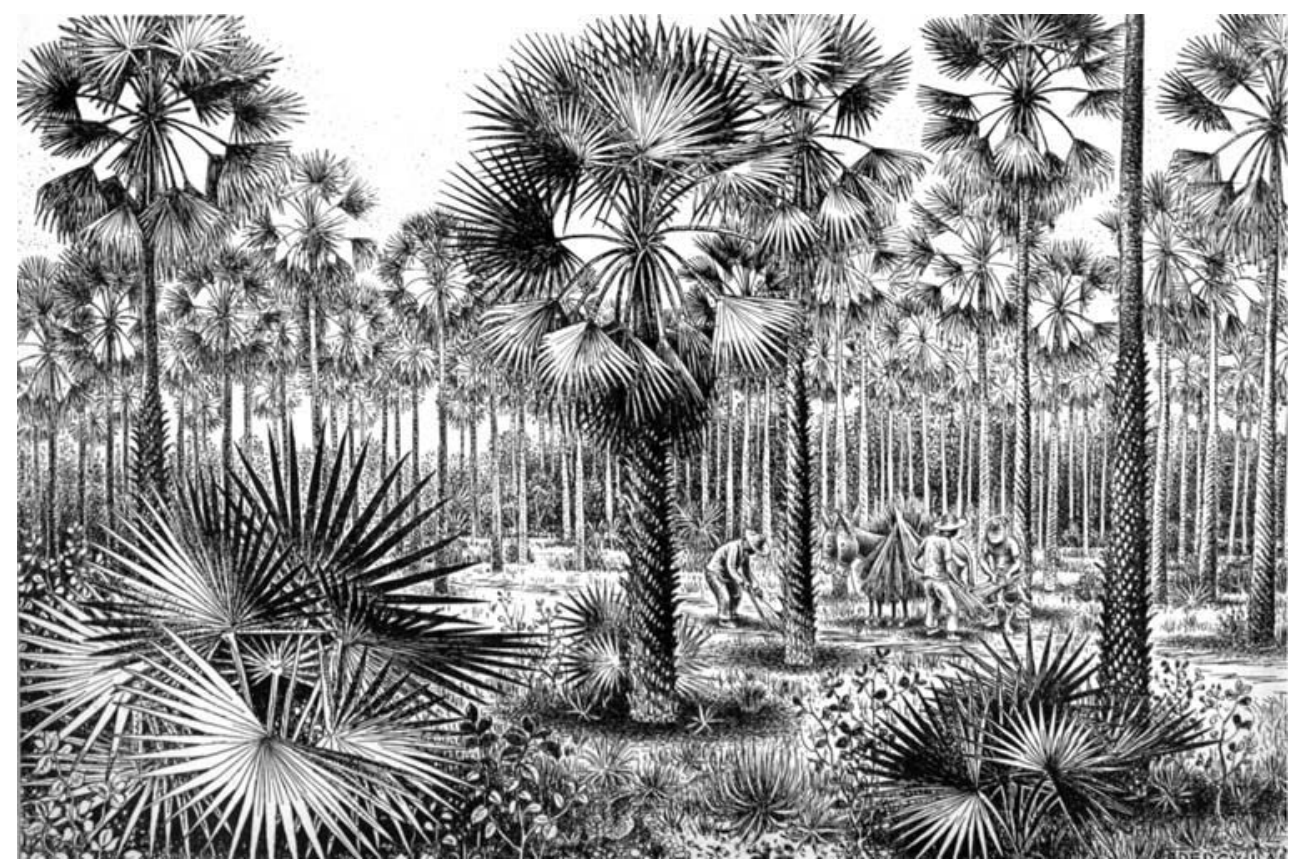

Figura 20 - Palmeiral de carnaúbas, desenho de Percy Lau para Tipos e aspectos do Brasil. Acervo da biblioteca do Instituto de Estudos Brasileiros da Universidade de São Paulo.

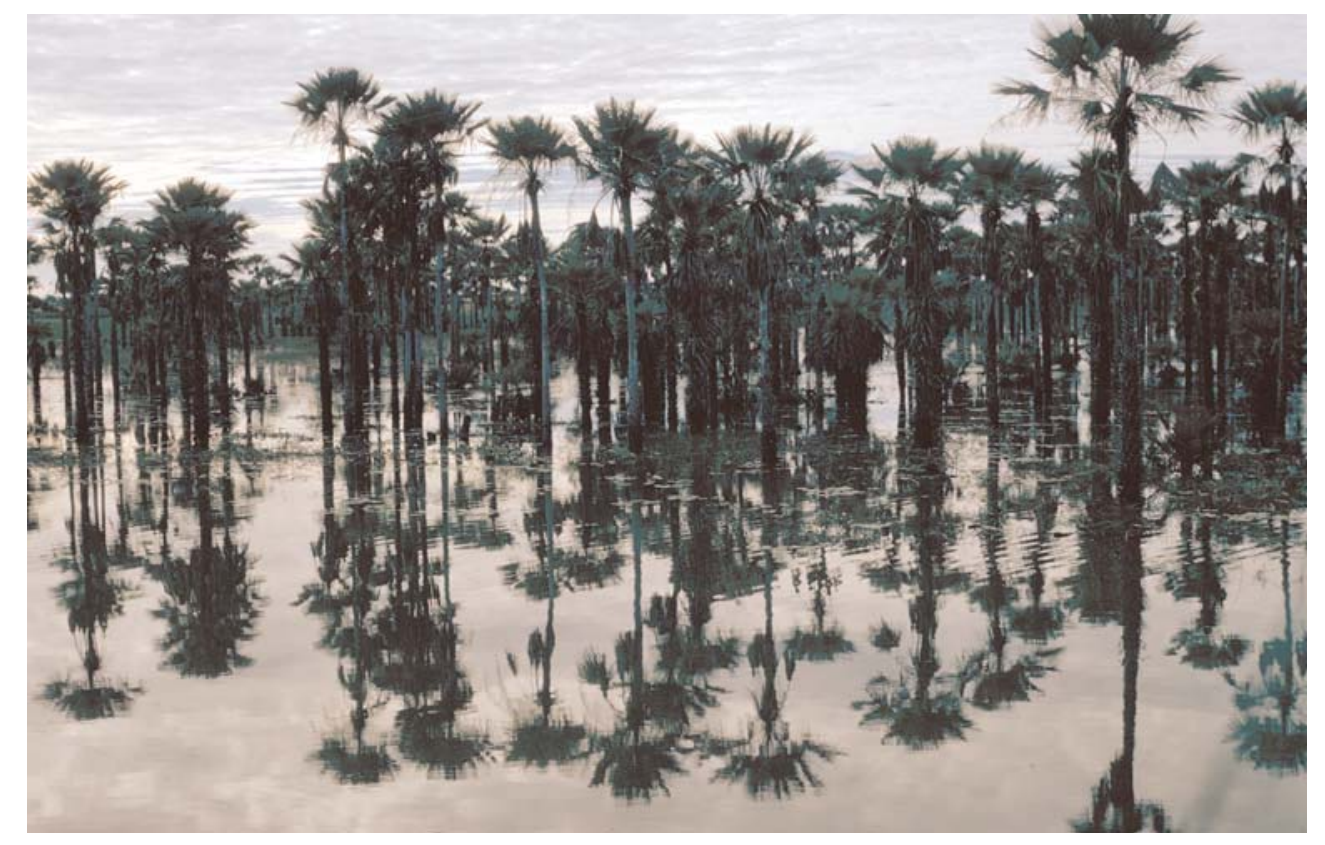

Figura 21 - Palmeiral de carnaúbas em igapó, Piauí, 1974. Fotografia de Pierre Monbeig. Copyright PRODIG/ CNRS, Paris. 


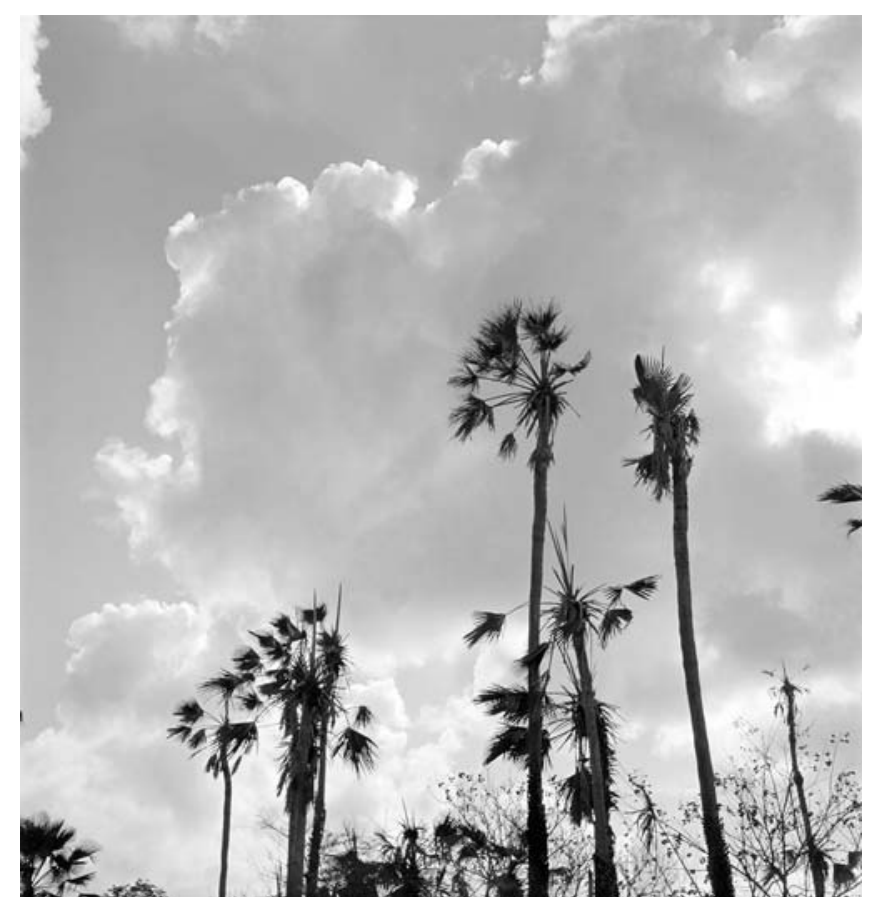

Figuras 22a a $22 f$ - Plantação de carnaúba, Messejana/CE, c. 1950-52. Fotografias de Marcel Gautherot. Acervo do Instituto Moreira Salles.

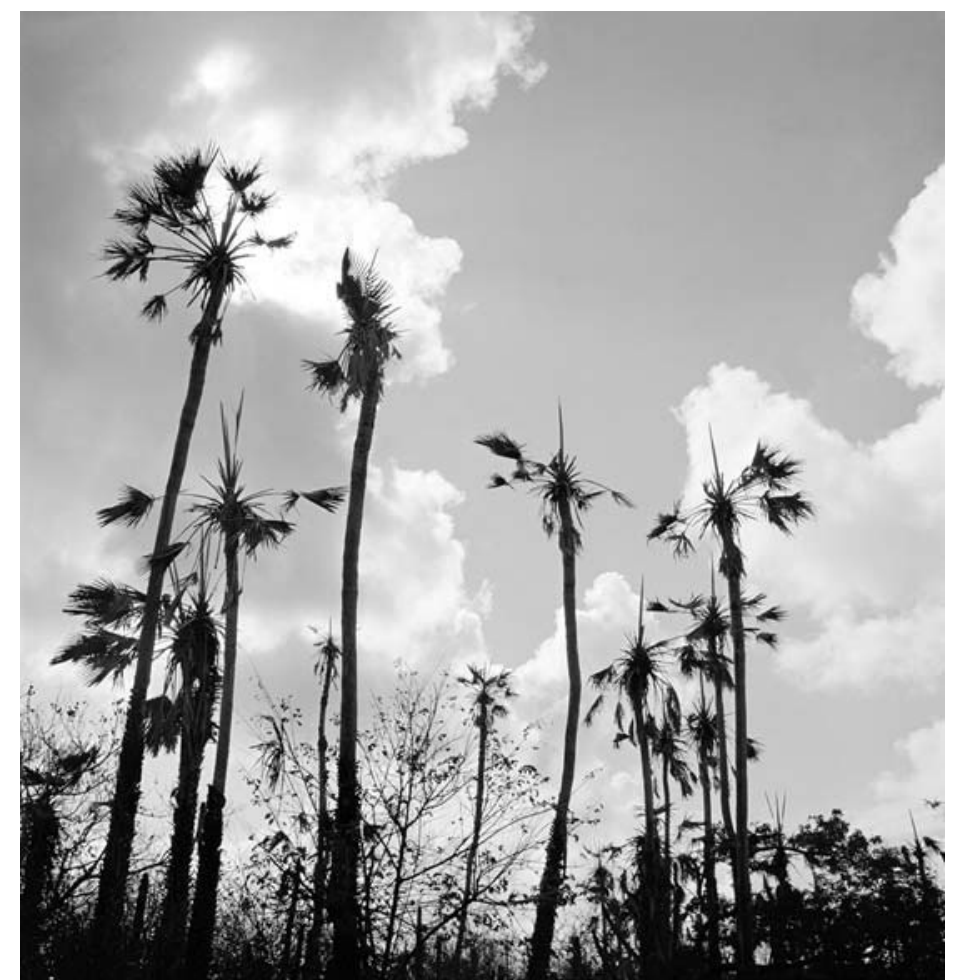

Annals of Museu Paulista.v. 13. n.2. Jul.- Dec. 2005. 

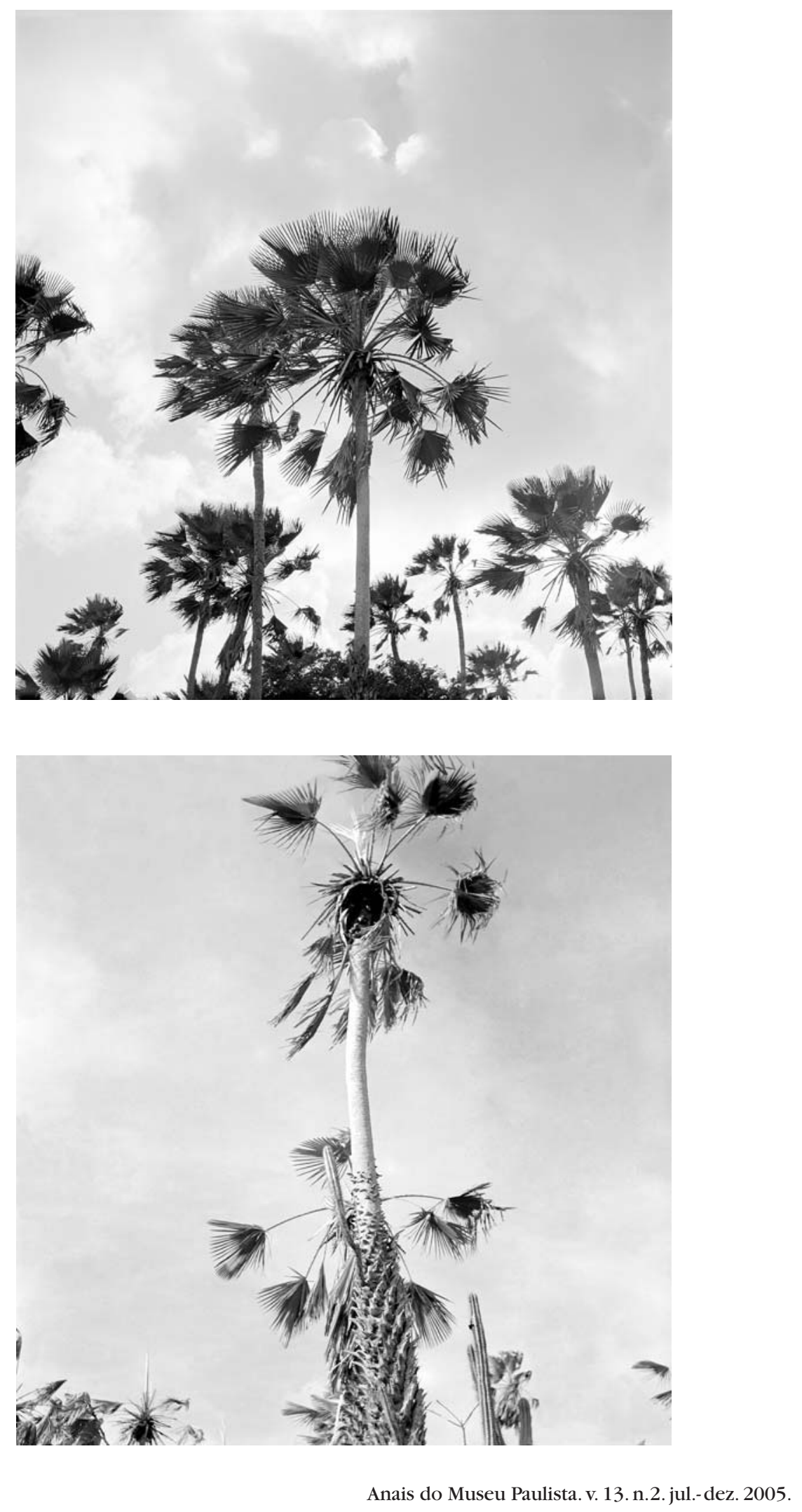

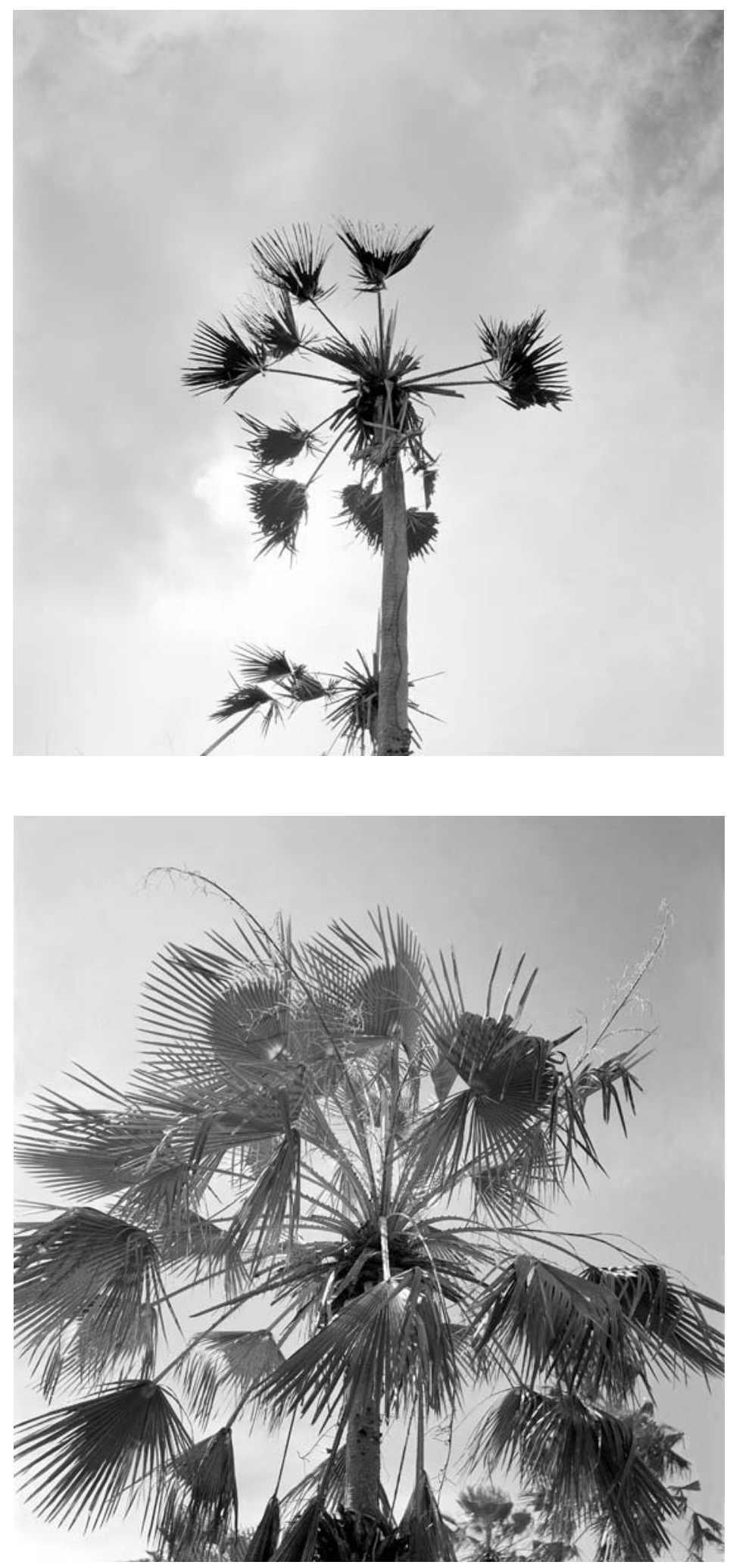

Annals of Museu Paulista.v. 13. n.2. Jul.- Dec. 2005. 
33. A vontade de repertoriar, classificar, fazer balanços historiográficos estava no ar do tempo lembremo-nos do artigo de Pierre Monbeig, Observações sobre o estado atual dos estudos geográficos no Brasil (publicado em uma nova revista "pluridisciplinar", como muitas da época, Rumo, em 1943) e do célebre Manual bibliográfico de seu amigo Rubens Borba de Moraes.

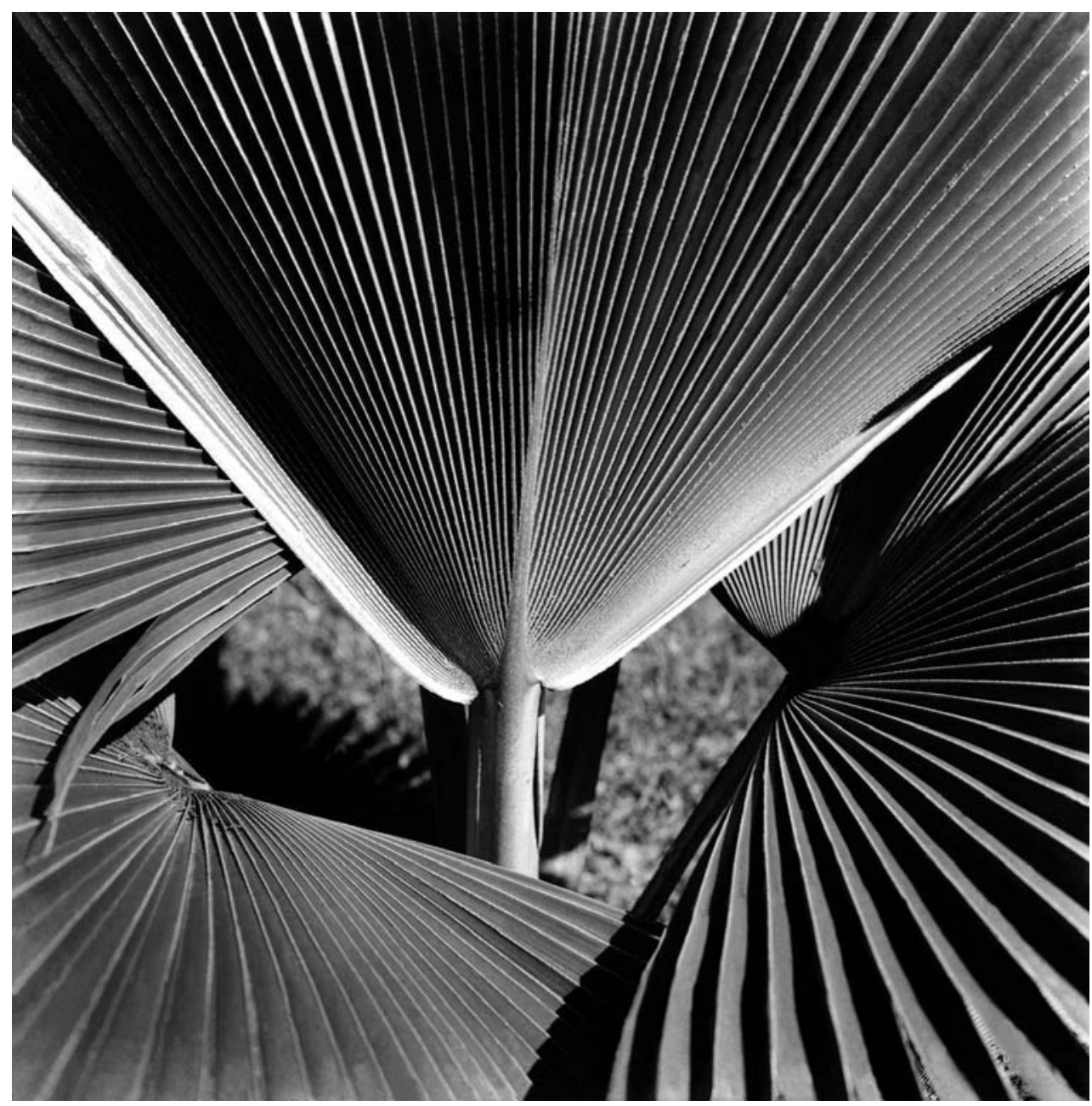

Figura 23 - Detalhe da folha de carnaúba, Messejana/CE, c. 1942. Fotografia de Marcel Gautherot. Acervo do Instituto Moreira Salles.

O boiadeiro (Figura 29) é um tipo das "pradarias abundantes" e extensivas encontradas em várias regiões do país. O tipo viaja todo o tempo: "é um espetáculo freqüente no interior do Brasil, a passagem das tropas nas estradas, no seu passo lento, em direção aos mercados consumidores". A travessia Norte/Sul e vice-versa pelas tropas é descrita por Nelson Werneck Sodré, cuja reputação se afirmará como autor de livros de referência crítica historiográfica durante gerações, como $O$ que se deve ler para conhecer o Brasil, em $1945^{33}$. Sobre as tropas em viagem ele escreve que no Brasil, "a travessia de rios e vales sempre foi um problema dada à imensidão do território e a precariedade das estradas que caracterizam as paisagens percorridas por estes homens nômades". A cena se repete em diapositivo colorido de Pierre Monbeig, na Belém-Brasília, em 1971 (Figura 30).

Introduzo aqui uma imagem da série Types et coutumes de France, 


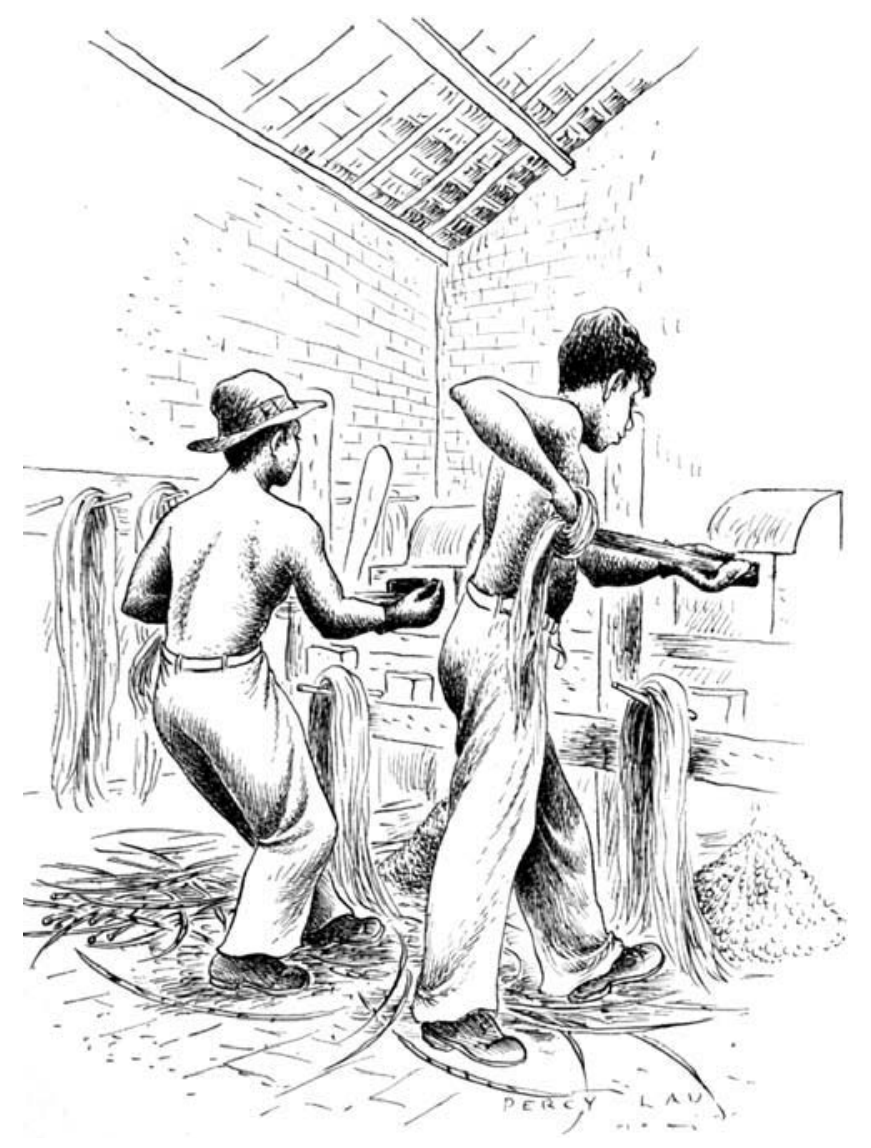

Figura 24 - As usinas de caroá, desenho de Percy Lau para Tipos e aspectos do Brasil. Acervo da biblioteca do Instituto de Estudos Brasileiros da Universidade de São Paulo.

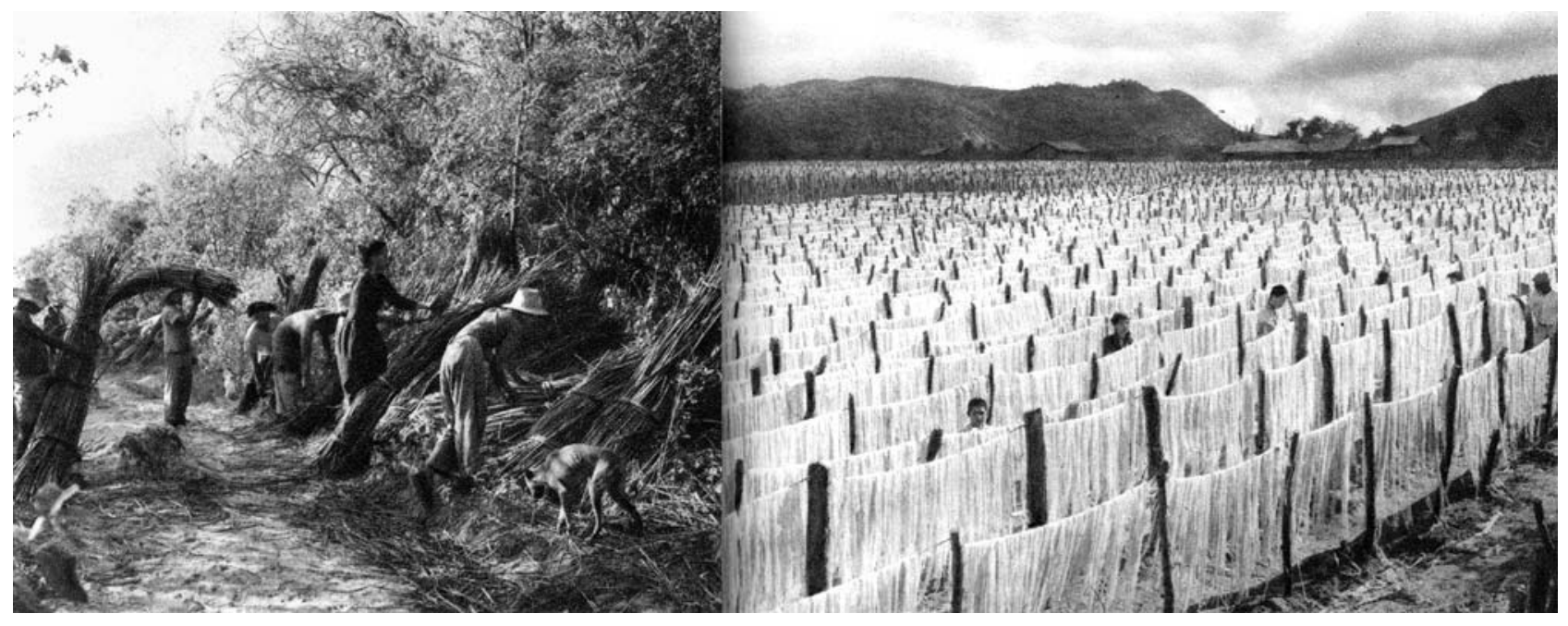

Figura 25 - Colheita do caroá, fotografias de Pierre Verger em Antoine Bon (org.), Brésil, Paris, Paul Hartmann ed., 1950. Acervo da biblioteca do Instituto de Estudos Brasileiros da Universidade de São Paulo. 


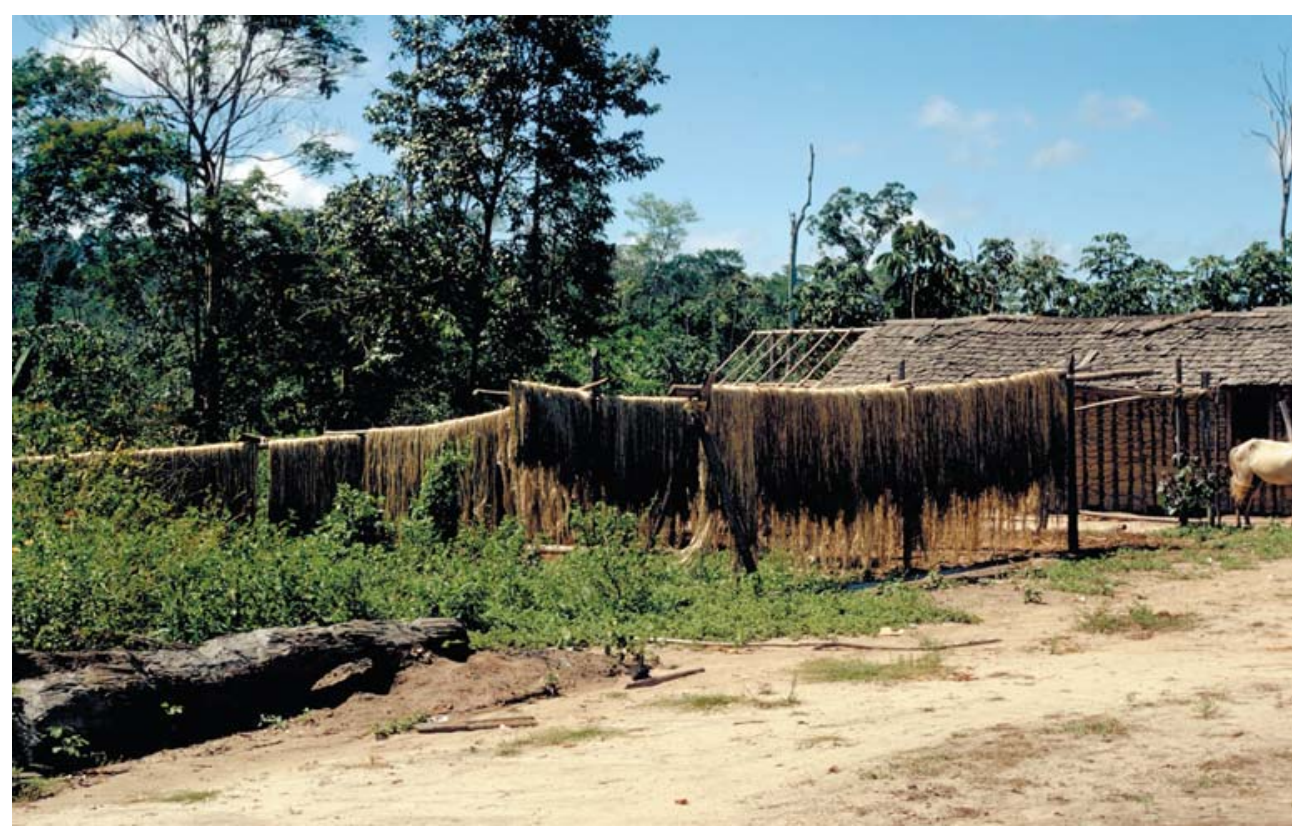

Figuras 26a e 26b - Secagem e seixos da malva de Santarém, 1971. Fotografias de Pierre Monbeig. Copyright PRODIG/ CNRS, Paris.

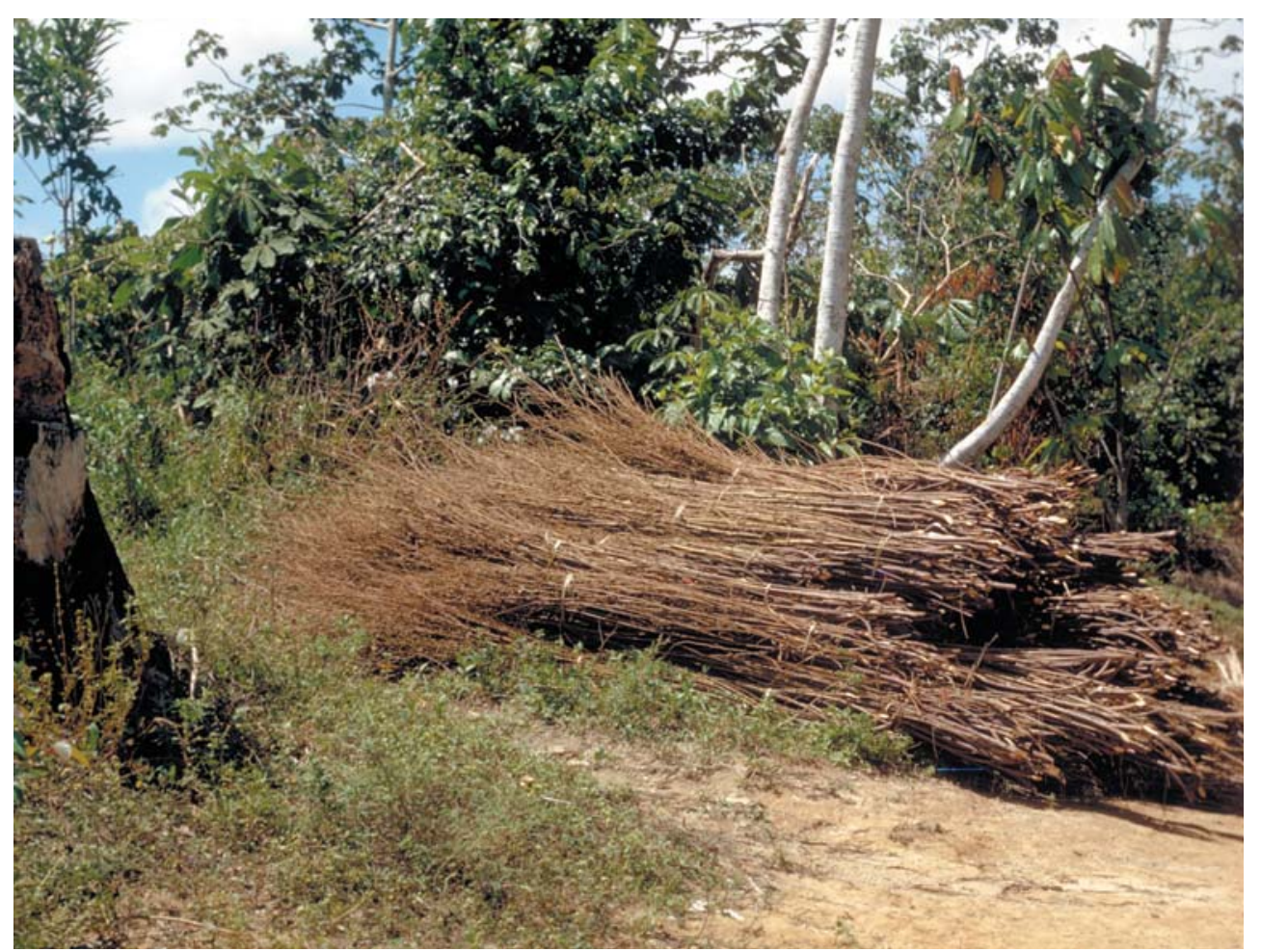




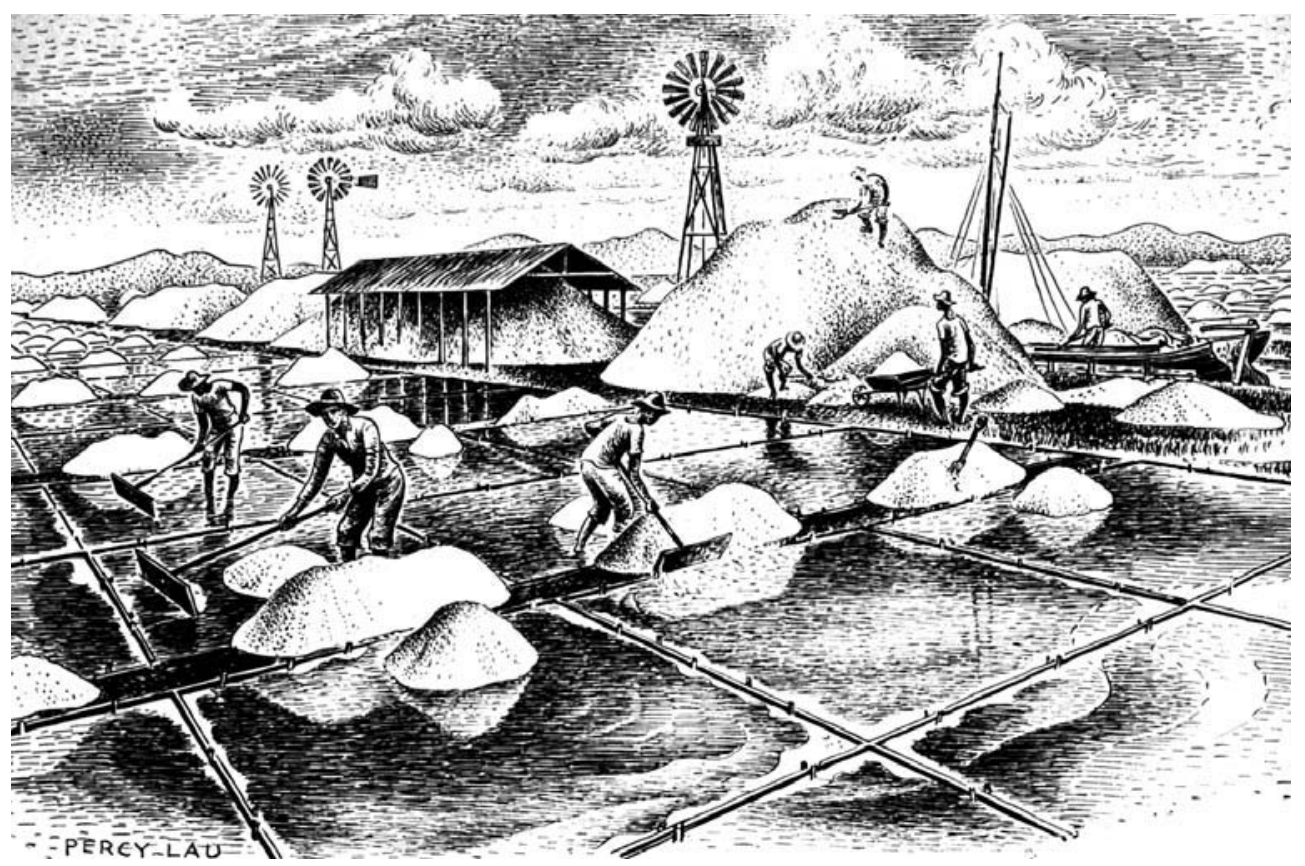

Figura 27 - Salinas, desenho de Percy Lau para Tipos e aspectos do Brasil. Acervo da biblioteca do Instituto de Estudos Brasileiros da Universidade de São Paulo.

pequenos livros que proclamam a unidade de cada região pelas "paisagens múltiplas de um só rosto" (Figura 31 ). O pastor da Provence e seu rebanho têm como pano de fundo o conjunto arqueológico de St. Rémy. Na França, identidade e patrimônio são indissociáveis - o patrimônio da petite patrie é constituído igualmente pelos "sítios e os panoramas, os monumentos históricos, os produtos regionais, os homens ilustres e o folclore" ${ }^{34}$. Nesse aspecto, uma diferença salta aos olhos em relação à figuração brasileira: por um lado, não se pode falar propriamente em associação de monumentos históricos às paisagens culturais da geografia dos Tipos e aspectos, salvo pela presença de uma ou outra vinheta; por outro, nem o mundo urbano, a mecanização agrícola ou o progresso industrial presentes nas séries francesas dos Types et coutumes aparecem. Na série brasileira estão ausentes referências patrimoniais edificadas ${ }^{35}$, que são valorizadas justamente na era getuliana - a consciência patrimonial era recente, a criação do Serviço do Patrimônio Histórico e Artístico Nacional (SPHAN) data de 1937-, bem como não há imagens dos anos da política desenvolvimentista do decênio de 1950, quando os Tipos e aspectos são muito populares. Eles se mantêm, assim, tradicionalmente ancorados ao ruralismo, à "simplicidade da vida econômica" como se o outro lado da nação não existisse. Não há contrastes, nem complementaridade entre esses vários mundos, mas escolhas que respondem à opção de registro das figuras paisagísticas do campo, do litoral, da produção artesanal e das formas de extração de produtos da natureza, hábitos e gêneros de vida em torno deles.

Nos Tipos e aspectos, estaríamos próximos da noção vidaliana de personalidade geográfica de um país, como a expressa no Tableau em relação
34. Cf. THIESSE, 1998, p. 76 .

35. O fato que igrejas de Salvador apareçam em pequena escala como pano de fundo para o episódio das Negras da Babia (Fig. 17), se referiria antes à presença dessas personagens nas festas religiosas, procissões e romarias do Senhor do Bonfim, mencionadas no texto.Há,porém, duas frases curtas no episódio "A região central de Minas Gerais/serra do Curraldel-Rei", sobre "a riqueza da arquitetura religiosa $\mathrm{e}$ a importância dos palácios construídos" no século XVIII, e "o ambiente favorável da riqueza de forças culturais que fez com que a arte brasileira produzisse em 1730 sua figura mais poderosa,Antonio Francisco Lisboa, chamado o Aleijadinho". Gautherot, como fotógrafo do SPHAN nos anos 1940, fará o registro de ambos em inúmeras séries divulgadas em revistas e livros internacionais, especialmente franceses. 


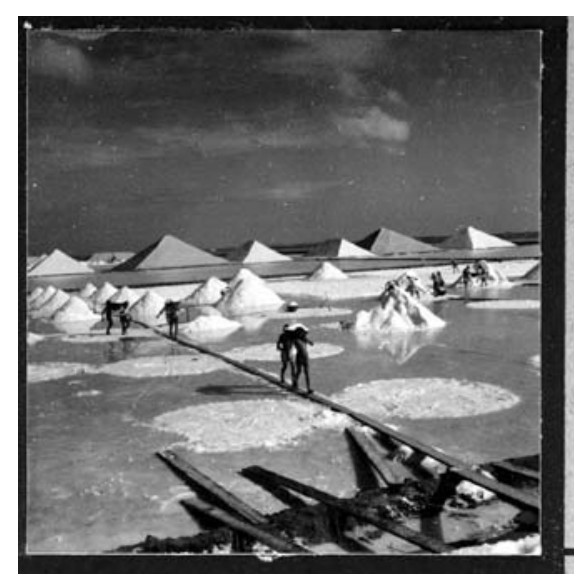

.6588

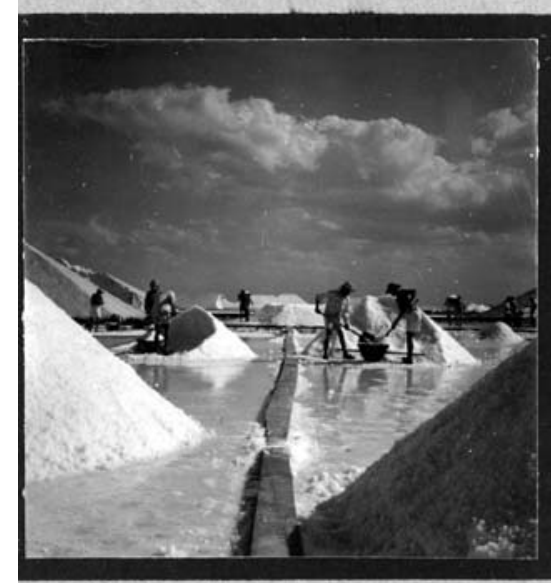

.6592

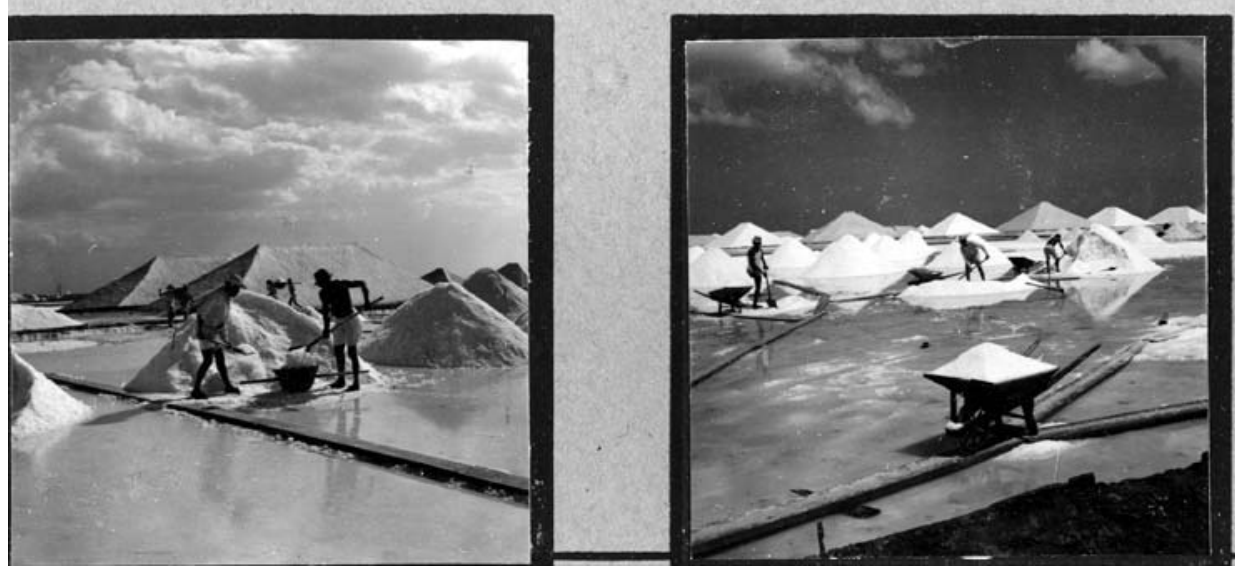

Figura 28 - Série de salinas, Macau/RN, c. 1945-1947. Fotografias de Marcel Gautherot. Acervo do Instituto Moreira Salles.

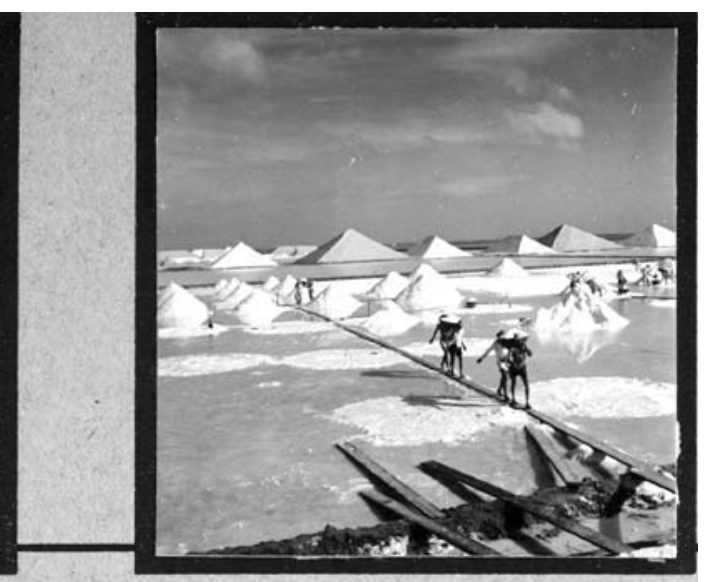

16589

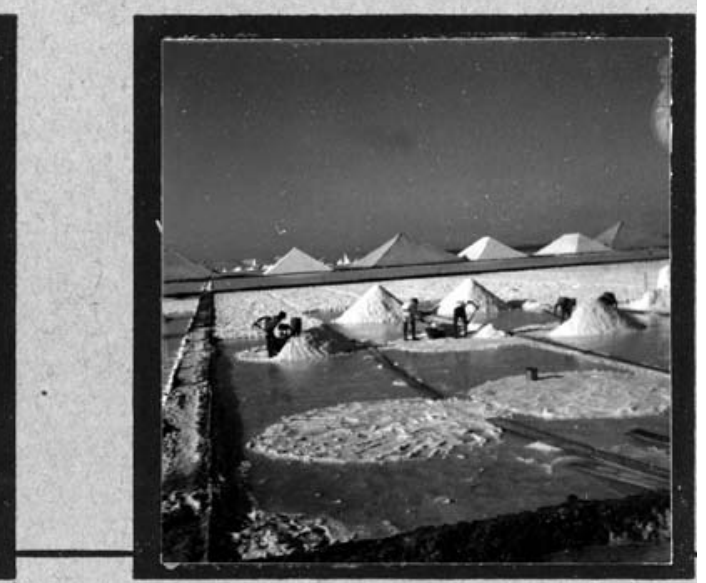

16593 

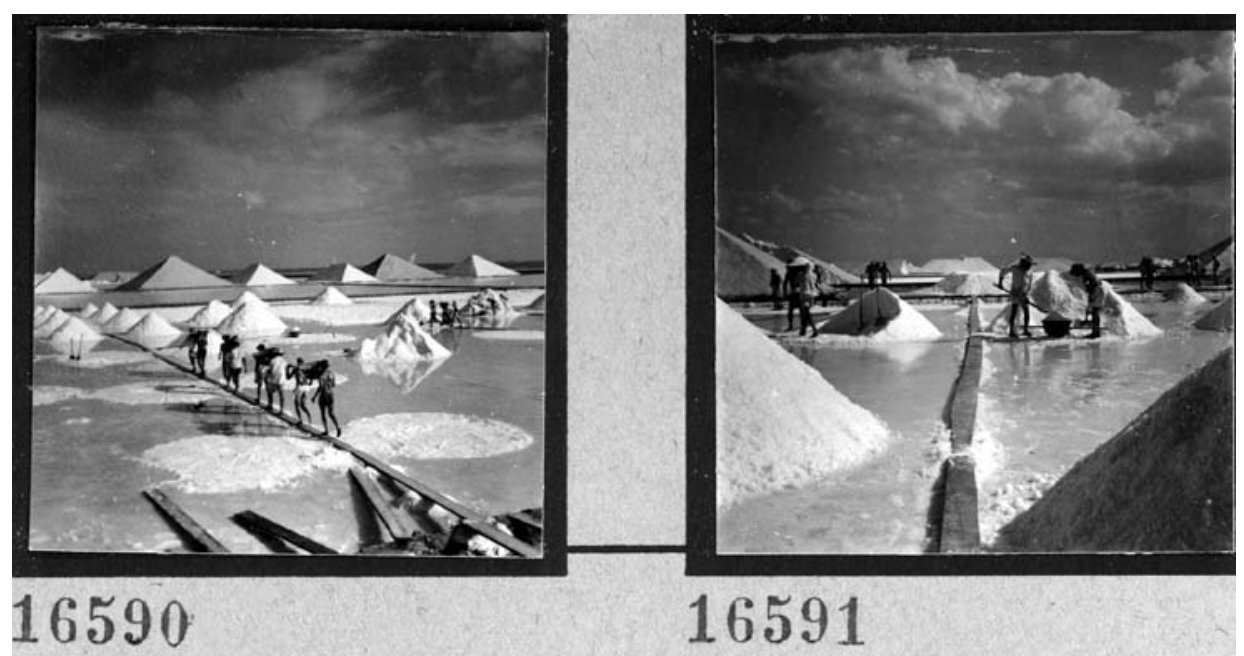

16591
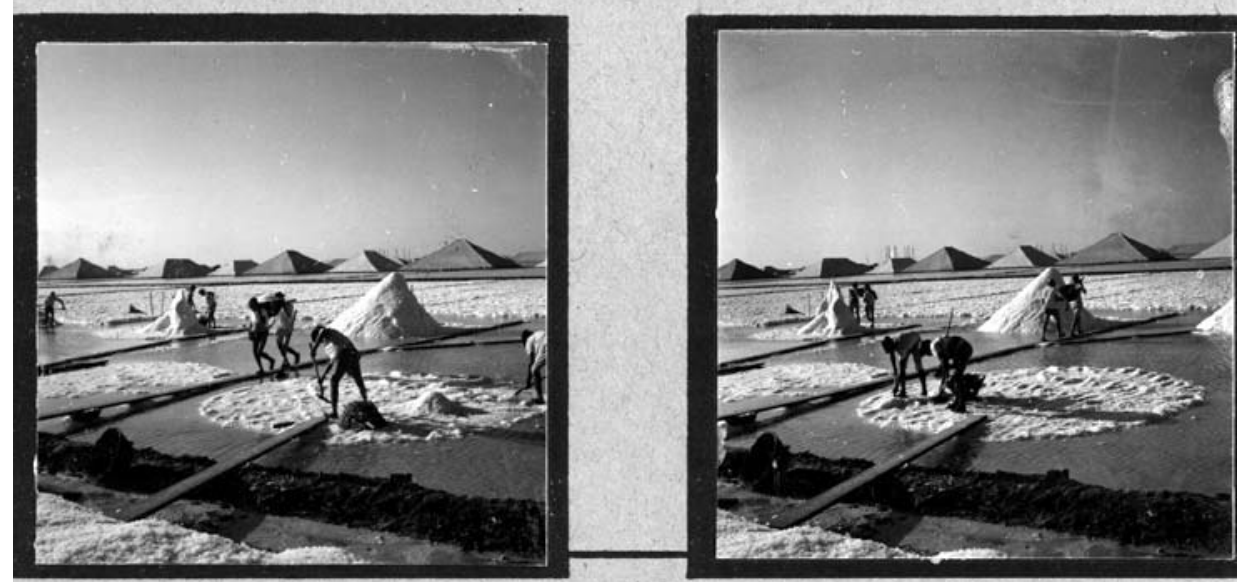

16594

16595
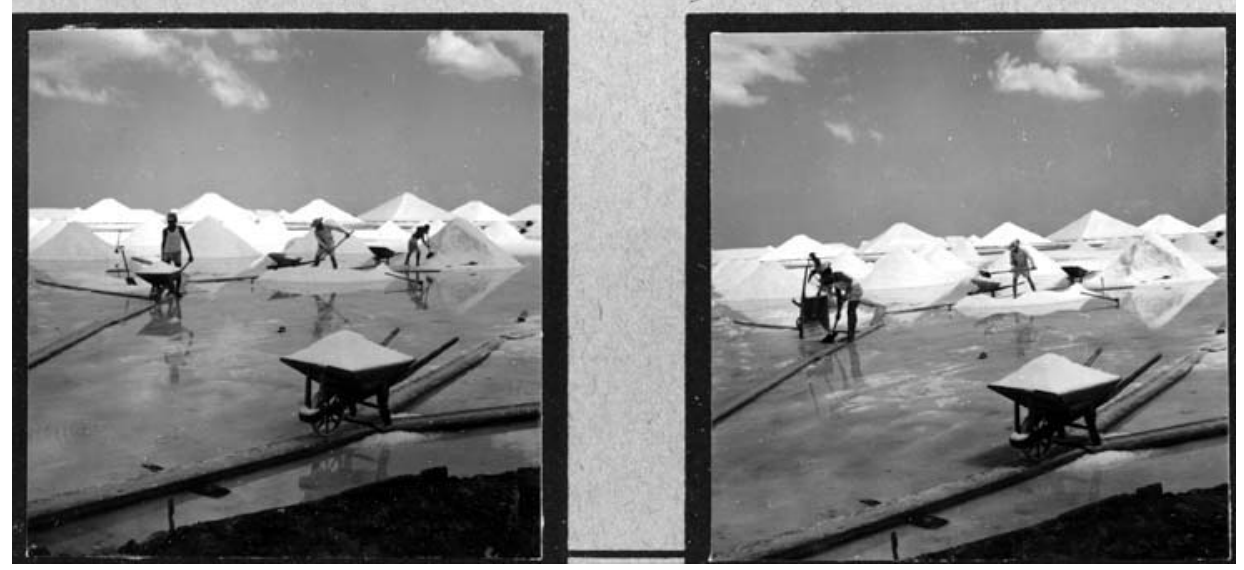


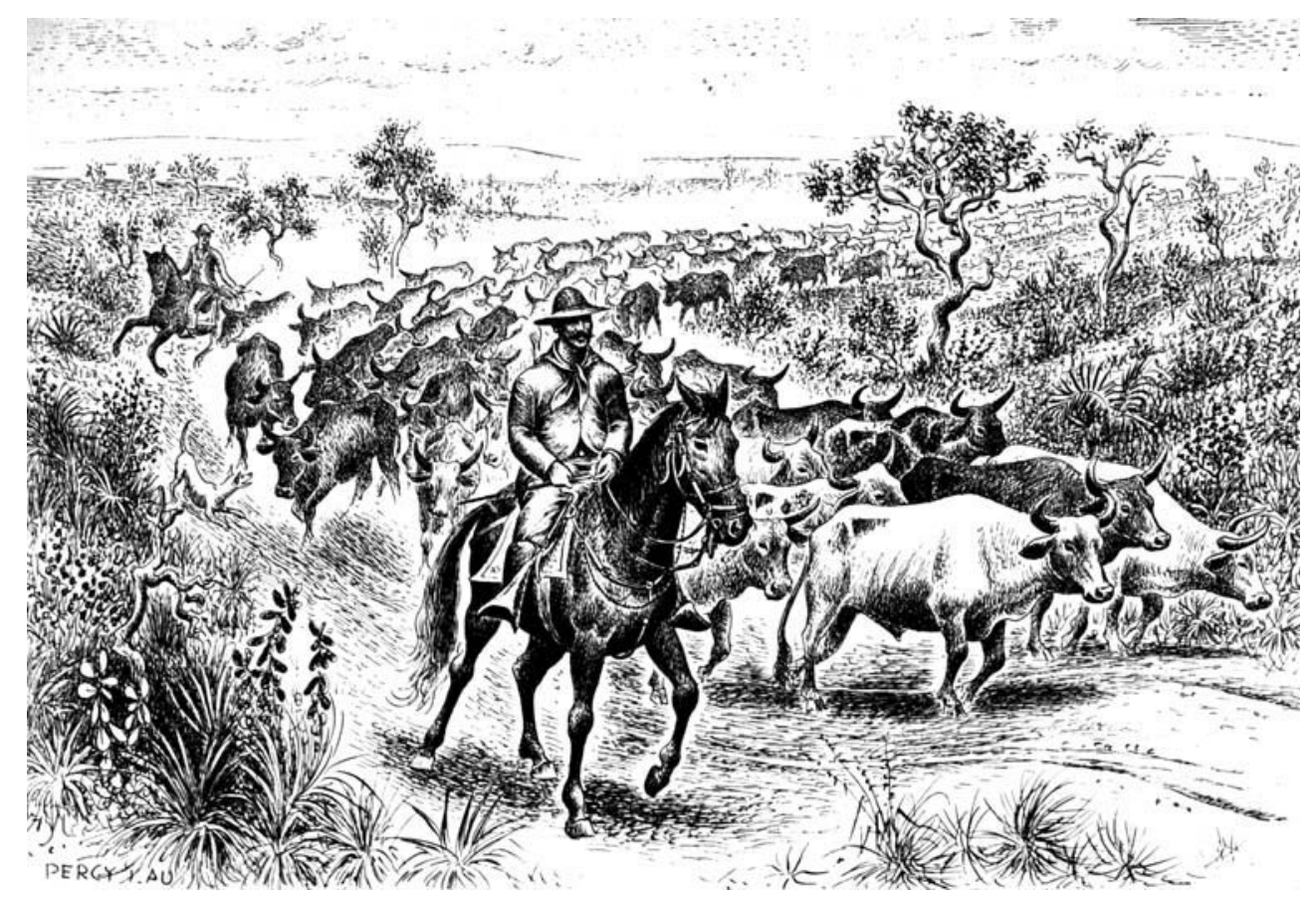

Figura 29 - Boiadeiro e tropa, desenho de Percy Lau para Tipos e aspectos do Brasil. Acervo da biblioteca do Instituto de Estudos Brasileiros da Universidade de São Paulo.

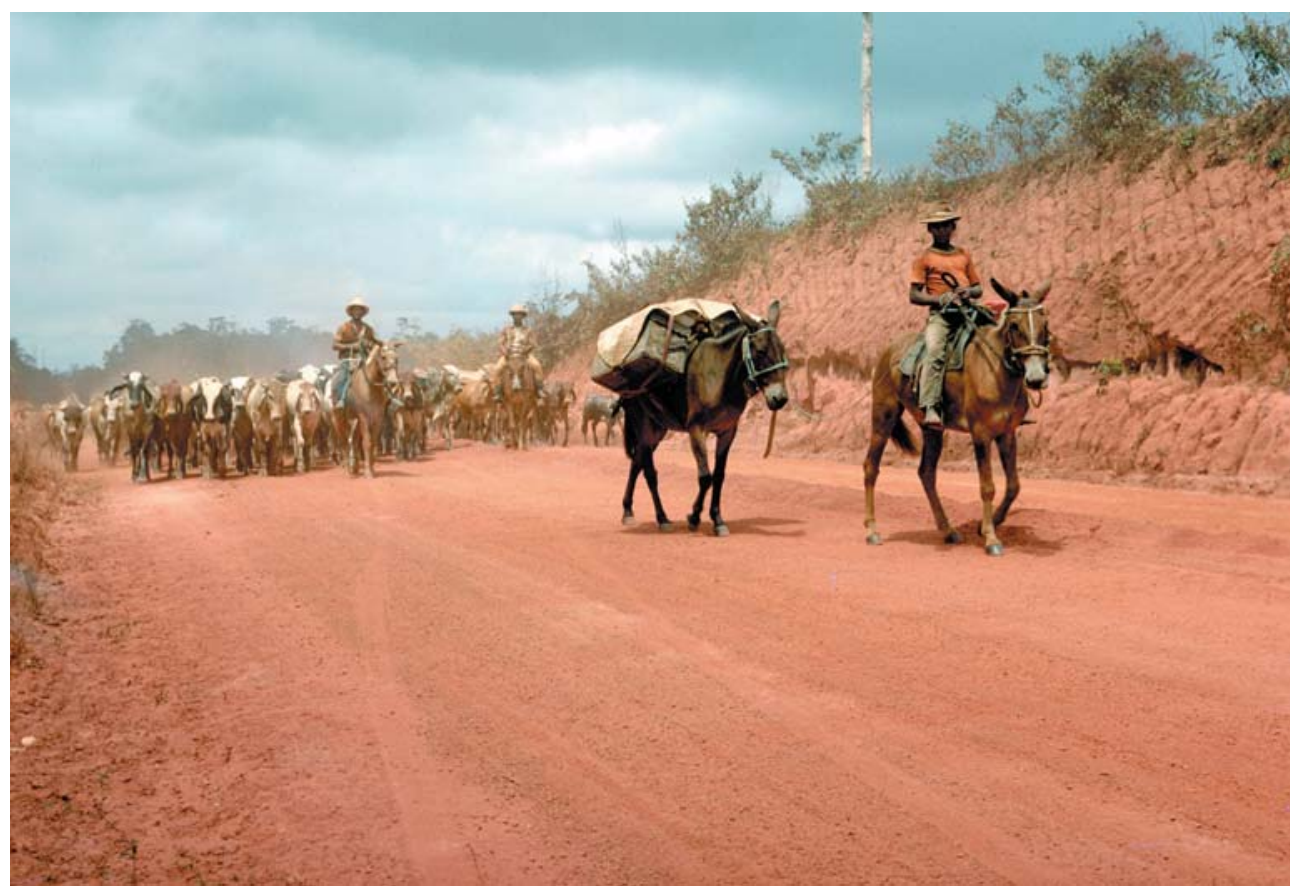

Figura 30 - Boiadeiro e tropa na estrada de Belém-Brasilia, 1971. Fotografia de Pierre Monbeig. Copyright PRODIG/ CNRS, Paris. 


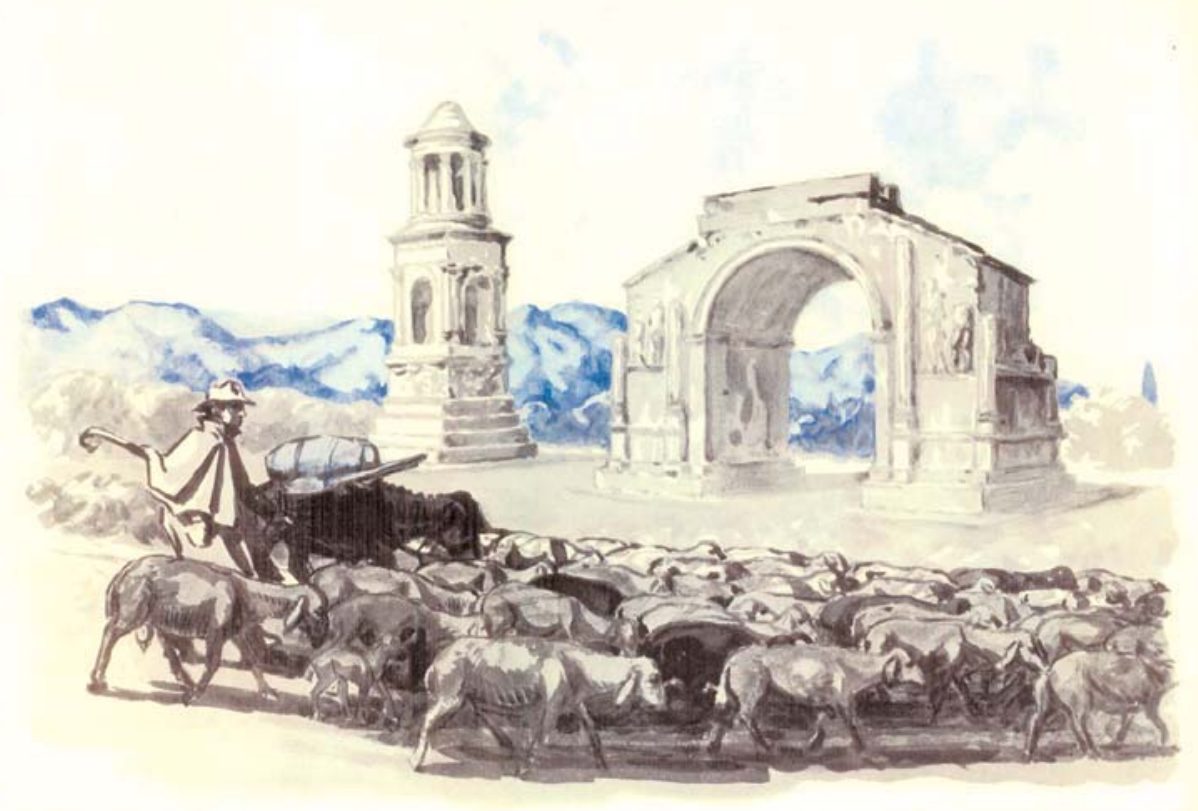

Figura 31 - Pastor da Provence, aquarela de François de Marialve, no livro Ceux de la Provence. Types et Coutumes, 1939. Coleção particular, Paris.

à França? Há em Vidal de la Blache a divisão do país em Norte e Sul, com base nos tipos de organização da vida local, de afirmação da unidade territorial, da unidade paradoxal na diversidade, nos contrastes espaciais e suas oposições que devem resultar na complementaridade. Nos Tipos e aspectos fragmentados regionalmente, a geopolítica da unidade está em construção.

Gostaria de voltar a Marie-Claire Robic que interpreta de forma aprofundada a questão da identidade nacional no Tableau de la géographie de la France, de Vidal de la Blache, reconhecendo nele a importância da biogeografia e da pesquisa de campo, novos métodos de investigação que estarão mais tarde na base da história dos Annales. Segundo Robic, os princípios da geografia territorial e regional estão sempre no âmago da construção da nação, e é o naturalismo, aos olhos da geografia humana, que define a identidade nacional, questão central nos Tipos e aspectos. A reflexão inspirou-me uma questão-chave: A imagem da nação seria conforme os estereótipos de uma imagerie construída ao longo do tempo e que se convencionaliza em momentos determinados, ou as imagens, afinal, estão todas lá, na realidade, esperando para serem captadas/escolhidas/recompostas pelo desenho ou a fotografia, em cenas cuja descrição apóia-se em monografias locais, na literatura, em outras fontes?

Para a primeira parte da questão resta reconhecer níveis e momentos dessa construção, como as representações se constituem e vão se instalando na memória visual, como se cristalizam os estereótipos que correspondem às escolhas 
36. Cf. ARBAUD, 1939, p. 45. Agradeço a Marie-Vic Ozouf-Marignier por ter assinalado essa e outras referências do gênero importantes para a comparação.

37. MANZON, 1950; sobre esse fotógrafo, que também fez séries de figuras típicas regionais, ver COSTA, 1998.

38. Relembro uma frase de Monbeig (1957, p. 236) - mesmo se dentro de um outro contexto que afirma a interpretação e não o mero registro descritivo:"A geografia não pode contentar-se em descrever a paisagem concreta; ela procura compreender e reconstituir o mecanismo que conduz à formação da paisagem e provoca sua evolução. Nem todos os elementos desse mecanismo são visíveis aos nossos olhos, mas se acham à disposição da nossa curiosidade crítica. Já se disse que o geógrafo é um olbo e a geografia uma maneira de ver. Jamais se pretendeu fazer do geógrafo uma Kodak insensível".

39. Expressões de ROUILLÉ, 2005, p. 94ss. de identidades territorializadas, e quem as percebe; quanto à segunda parte da questão, lembremo-nos da importância do registro documental dos tipos e paisagens, que remonta a séculos anteriores, do registro da realidade, como se lê no texto que acompanha a imagem da Provence, também de 1939, que assinala justamente a concretude do personagem retratado e não a construção ficcional e mítica do tipo:

[...] o pastor da Provence existe. Inútil inventá-lo. Porém, se ele não se parece com um feiticeiro de teatro, não o reconhecemos, o mesmo se dá nas ficções mais modernas de um lirismo romanceado. A literatura é implacável. Depois do camponês falso de La terre, eis o falso pastor e o falso aldeão. Mas a moda não interessa pois o importante é não separar o homem de sua verdade eterna. Este aqui [referindo-se à imagem] simplesmente faz seu trabalho, ele não precisa de uma suposta grandeza ${ }^{36}$.

No caso da fotografia, é preciso não esquecer que sua função primeira é documentária. Mesmo se em vários casos, como o de Gautherot, passa-se muitas vezes do conteúdo à forma estética, ou, em outros casos, como o de Jean Manzon $^{37}$, que trabalhava diretamente junto ao governo Vargas como responsável pelo Setor de Fotografia do DIP, de onde saíam fotos para a divulgação da imagem do Brasil no país e no exterior, se está diante de composições estudadas, de construções artificiais, não raro sensacionalistas, na linha do fotojornalismo. Para a maioria dos geógrafos-fotógrafos os aspectos materiais da vida dos grupos sociais na paisagem são objeto de simples registros, embora Pierre Monbeig conteste que sejam captados por uma "Kodak insensível" ${ }^{38}$, ou não passem de croquis diários de campo, que Pierre Deffontaines recomendava ao "viajante ativo".

No prefácio dos Tipos e aspectos atribui-se o estatuto de "documentos geográficos" às imagens da série. O artigo "Arquivo fotográfico do geógrafo" fixa temas e códigos; a "coleção de fotografias", reza o artigo, se faz com "dados que se collhem diretamente da realidade", as fotografias funcionam como "registro", para "rememorar" e "reestabelecer" com "fidelidade" o que foi visto. Para uma ciência que se caracteriza pelo estudo dos "fenômenos que se verificam no espaço", ciência portanto da "observação que exige multiplicidade de visões" (do texto do artigo, citando P. Deffontaines, em sua Géographie humaine) e que tem um caráter científico e filosófico, mas também um caráter descritivo e realista" (o grifo é meu), estabelece-se um "plano para fotografias geográficas do Brasil", que parte de duas entradas: "Paisagem" e "O Homem" - que são justamente as mesmas que direcionam a concepção dos Tipos e aspectos.

A insistência em retratar a realidade, praticada pela geografia e a etnologia desde o final do século XIX, comprovada nos textos e coleções, parecenos hoje um debate datado, pois sabemos que são os padrões culturais que estão na base da percepção dos grupos que registravam as cenas e tipos; no caso específico da representação fotográfica, além da função documental e arquivística clássica desse medium a serviço das duas disciplinas, sabe-se hoje que o caminho da "coisa à imagem nunca é direto [...] a fotografia não registra jamais sem transformar, construir, criar" ${ }^{\prime \prime 2}$. 
A abertura à fenomenologia e à história cultural possibilitou ir além da oposição artificial entre a realidade e a representação - assim, nos estudos da paisagem, defende-se também hoje a presença de uma natureza objetivada, não se acreditando mais na "invenção" das suas representações, uma vez que já passamos pela ilusão culturalista da paisagem do final dos anos 1980 que nos prendia ao seu discurso e nos isolava do contexto e das práticas sociais trata-se sobretudo de recuperar os "regimes de historicidade" da paisagem, os contextos e condições específicas da emergência de determinadas representações ${ }^{40}$ e especialmente de estudar "fluxos, itinerários, trajetórias"4l dos homens, atores de sua construção. Assim, em relação às representações do Brasil, de Percy Lau nos Tipos e aspectos e no acervo de Pierre Monbeig, estão em jogo o olhar da geografia e das instituições a ela relacionadas, assim como em Gautherot, fotógrafo profissional e estrangeiro, há de se entender suas relações com os encomendantes nos contextos particulares em que opera, e, num outro nível, como as representações circulam entre eles.

As imagens dos Tipos e aspectos são cenas concretas de uma realidade muitas vezes intemporal que apenas se deslocou para mais longe. Estamos diante de paisagens que existem ainda em algum lugar do Brasil, de aspectos materiais da vida dos homens do campo, de técnicas pastorais e de formas artesanais de extração de produtos da natureza, de indústrias regionais tradicionais, de hábitos alimentares, de meios de transporte, dos ciclos econômicos da história do Brasil (da colheita de cana ao garimpo e ao cafezal)... Basta viajar nos confins do país para rever ainda muitas dessas cenas. A questão principal não é, portanto, a "invenção" das representações como se convencionou dizer, mas sim saber o que ficou fora do repertório de desenhos e fotografias e as razões de escolhas, recusas e reiteração de registro e do caráter que assumem ao longo do tempo. Nos anos 1970, observa-se na Apresentação à décima edição, que a publicação já era um "símbolo" do IBGE, ou seja, "flagrantes característicos do homem e da paisagem do Brasil ainda não tocados pelo mecanicismo do progresso e, por conseqüência, constituidores de memórias que o tempo vai esmaecendo".

Voltando às linhas da geografia presentes ao longo do livro, destaco a inscrição dos tipos na geografia psicológica, campo de estudo próximo da história das mentalidades, em voga na época. Justamente, La géographie psychologique de Georges Hardy foi objeto de uma longa resenha na Revista Brasileira de Geografia, em 193942, quando começam a circular os Tipos e aspectos. Hardy publica na coleção de geografia humana de Deffontaines, inscrevendo-se como ele nos meios intelectuais católicos. Nessa obra, Hardy cria a noção de paisagem psicológica, colocando a geografia a serviço da psicologia, na medida em que ela é uma ciência da análise da materialidade concreta dos fatos, inventariando os hábitos das comunidades. Segundo análise de Marie-Vic Ozouf-Marignier são estes:

[...] os hábitos corporais (movimento do corpo, gesto, mímica, modo de vestir-se e de portarse, expressão do olhar, ritmo da fala); os hábitos materiais (alimentação, vestimenta, habitação, higiene e medicina, transporte, horizontes de trabalho ${ }^{43}$ ); os hábitos morais (vida religiosa, vida moral); os hábitos sociais (família, vida social, Estado); os hábitos psíquicos
40. Essa questão foi discutida na Journée d'études Paysage et territoire, em torno do livro de WALTER, op. cit. E a expressão "regimes de historicidade" é explicada por François Hartog, que a toma de empréstimo a antropólogos (2004, p. 18-20).

41. Expressões do título de artigo de referência sobre a microestória de Jean-Claude Passeron (1990).

42. Cf. GIBERT, 1939, p. 110-113.

43. "Horizonte de trabalho" é expressão emprestada a Brunhes e a Deffontaines por Hardy, muito presente nas descrições dos Tipos e aspectos do Brasil. 
44. ROBIC, 2000

45. Cf. OZOUF-MARIGNIER, 2006. Do seu texto extremamente elucidativo sobre a história intelectual e as redes de relações na primeira metade do século XX, depreendese que as experiências do deslocamento na carreira de intelectuais como desses geógrafos passeurs de frontières os teria predisposto a outra sensibilidade e à busca de ferramentas científicas alternativas aos métodos adquiridos e preestabelecidos. Monbeig, entre eles - basta lembrar seu significativo artigo Les modes de penser dans la géographie humaine, publicado originalmente na coletânea em homenagem a seu amigo Lucien Febvre, em 1953, e no mesmo ano em português no Boletim Paulis ta de Geografia, sendo retomado depois no conhecido Novos estudos de geografia bumana, que reuniu ensaios de Monbeig em 1957. (linguagem, hábitos intelectuais, afetivos). A descrição desses hábitos é o tema principal do livro. Trata-se de estudo da distribuição geográfica da diversidade psicológica. Mas Hardy tem consciência, entretanto, de que esse elo estabelecido entre a psicologia coletiva e a geografia é tênue demais. Então ele constrói a noção de paisagem psicológica: os hábitos descritos se traduzem antes, segundo ele, nas organizações do meio físico, num tipo de habitat, etc. Essa paisagem é percebida de múltiplas maneiras: pela visão, a audição e o olfato. Configura-se aqui uma geografia sensível que estava presente nos textos de Vidal de la Blache ${ }^{44}$. Portanto é por meio da pesquisa de campo e dos métodos iconográficos (mapa, desenho, fotografia, cinema) que aquela paisagem pode ser percebida [e captada]. $\bigcirc$ próprio Hardy tem preferência pela fotografia, como os demais geógrafos (Brunhes, Deffontaines, Monbeig e muitos outros) ${ }^{45}$

É bom ressaltar que Georges Hardy fez parte de sua carreira na África negra, onde funda instituições de ensino dando um impulso importante à vida cultural e à instrução nas colônias e territórios do ultramar (ele esteve também na Argélia), sua reflexão sobre a geografia psicológica, continua Ozouf-Marignier, é obra de maturidade, fruto de experiências de observação vivida em vários lugares, onde registrou cenas que se repetem na vida cotidiana dos povos (Figuras 32 e 33).

A linha de descrição de caracteres, hábitos e comportamentos que se inscrevia na geografia psicológica, no ar do tempo, explicita-se em vários episódios dos Tipos e aspectos combinado-se a outras, como no episódio de "O vaqueiro do Rio Branco": "honestos, bons, servis, hospitaleiros, eles continuam a realizar na clareira da floresta amazônica o milagre da humanização de uma paisagem situada bem longe dos grandes centros da civilização nacional". Ou nos "Barranqueiros ou ribeirinhos do São Francisco" (Figura 34), em que "a influência do clima no comportamento" leva a descrições dos traços físicos e comportamentais marcados por estereótipos, mas explicados pela óptica médica da geografia tropical: "atacado pelo impaludismo, pela opilação, pelo bócio, pelo mal de Chagas, seu aspecto exterior se reduz ao de indolente vulgar, sem estímulo para a luta pela vida".

Os meios de transporte também são listados no "Arquivo fotográfico do geógrafo" e sempre representados em imagens caras à geografia humana (Figura 35). Entre as gaiolas e vaticanos da Amazônia (que Mário de Andrade, Gautherot e Monbeig também captaram), a jangada do Nordeste (idêntico radeau também aparece nos Types et coutumes de Francel e o singular carro de boi, destaco o episódio "Carroças coloniais do sul". Lemos aqui que o Brasil possui uma coleção variada de meios de transporte típicos (essa palavra é tão repetida nos anos 1930-1940 quanto pitoresco nas narrativas de viagem do século $X|X|$, e que as carroças

[....] vêm de terras longínquas e bem diferentes, trazidas pelo estrangeiro imigrante da Europa central para o plateau meridional do Brasil [...] que ela se multiplica rapidamente, graças à abundância do material essencial destinado à sua construção, a madeira [...] estima-se em uma centena de milhar o número dessas carroças espalhadas pelo Paraná, Santa Catarina e Rio Grande do Sul. 


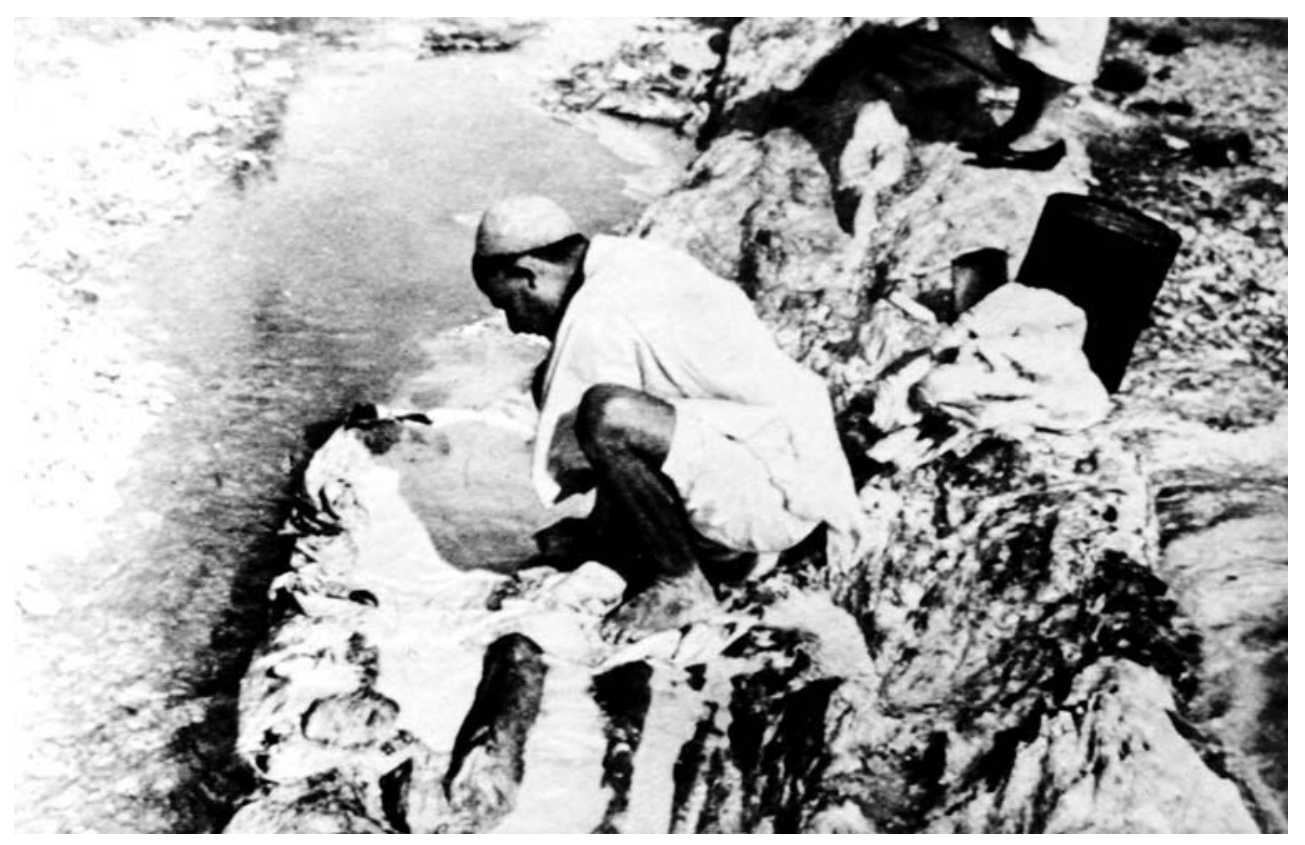

Figura 32 - Bou Saada, "no leito de um riacho, a cada um sua maneira de lavar roupa", em Georges Hardy, La géographie psychologique, Paris, Gallimard, 1939. Acervo da biblioteca da Faculdade de Filosofia, Letras e Ciências Humanas da Universidade de São Paulo.

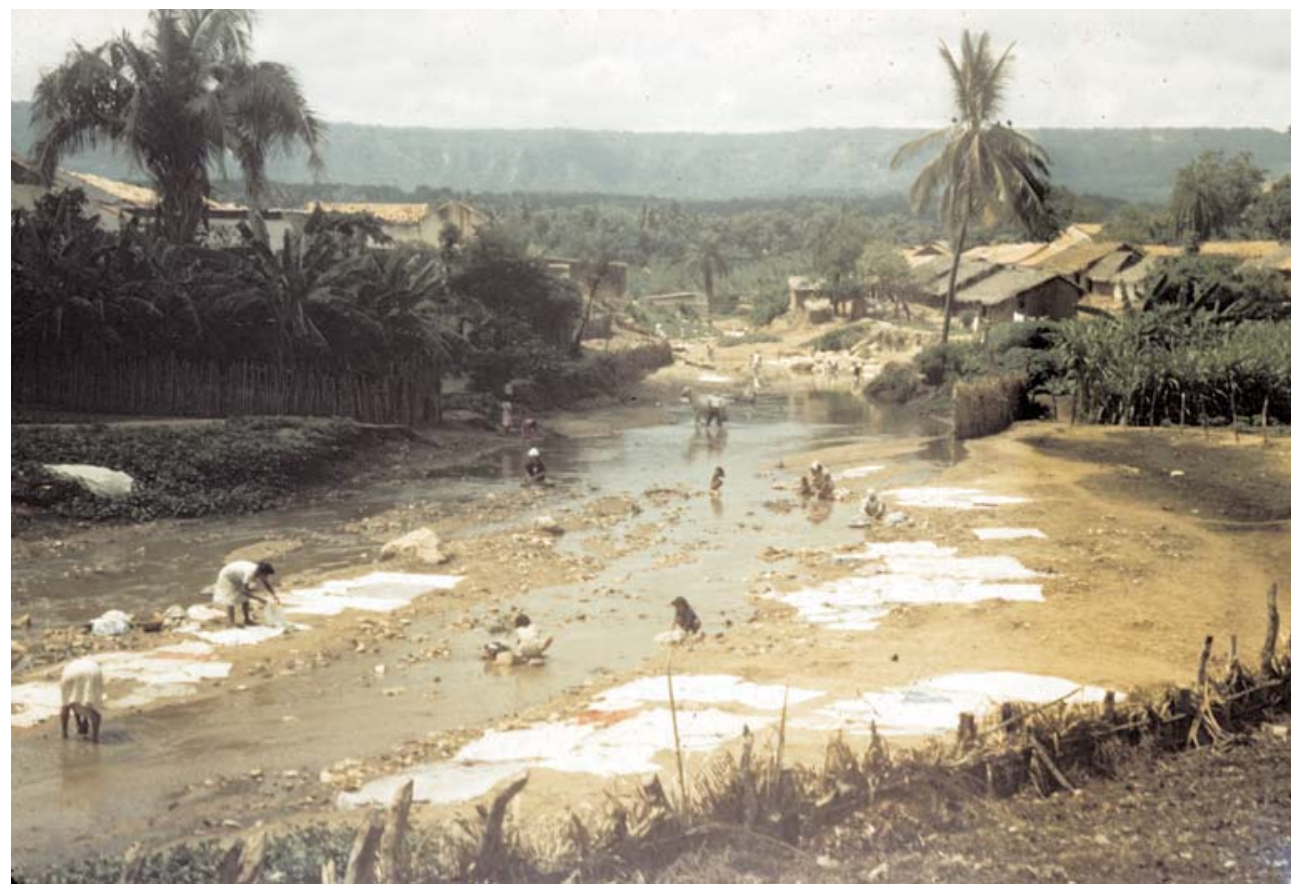

Figura 33 - Lavadeiras, Ceará, 1944. Fotografia de Pierre Monbeig. Copyright PRODIG/ CNRS, Paris. 
46. Cf. SEYFERTH, 1997. Os imigrantes não representarão jamais o Brasil dos Tipos e aspectos, nem mesmo nos episódios das regiões Leste e Sul onde constituem maioria; os colonos são citados, mas não aparecem nos desenhos; nem tampouco os índios (embora mencionados no texto como formadores da raça brasileira); há as "negras da Bahia", mas os mestiços predominam, pois ainda vigorava a noção de "caldeamento" de raças. Os tipos brasileiros das séries de Verger e Gautherot também são mulatos ou negros. Nos anos 1920, Oliveira Vianna havia observado as dificuldades da determinação de um tipo antropológico brasileiro único, afirmando sua "incomparável variedade somatológica". Cf.VIANNA, 1922 p. $277 \mathrm{ss}$.

47. Datam desse período estudos críticos em várias áreas das ciências sociais, hoje bem estudados, como os de Sérgio Buarque de Holanda, Gilberto Freyre, Caio Prado Jr., da mesma forma que editam-se coleções como a Brasiliana (da Cia. Editora Nacional, que dominará a indústria do livro até os anos 1970) ou a Documentos Brasileiros, na trilha de reedições de obras-chave para o conhecimento sociológico e histórico do Brasil.

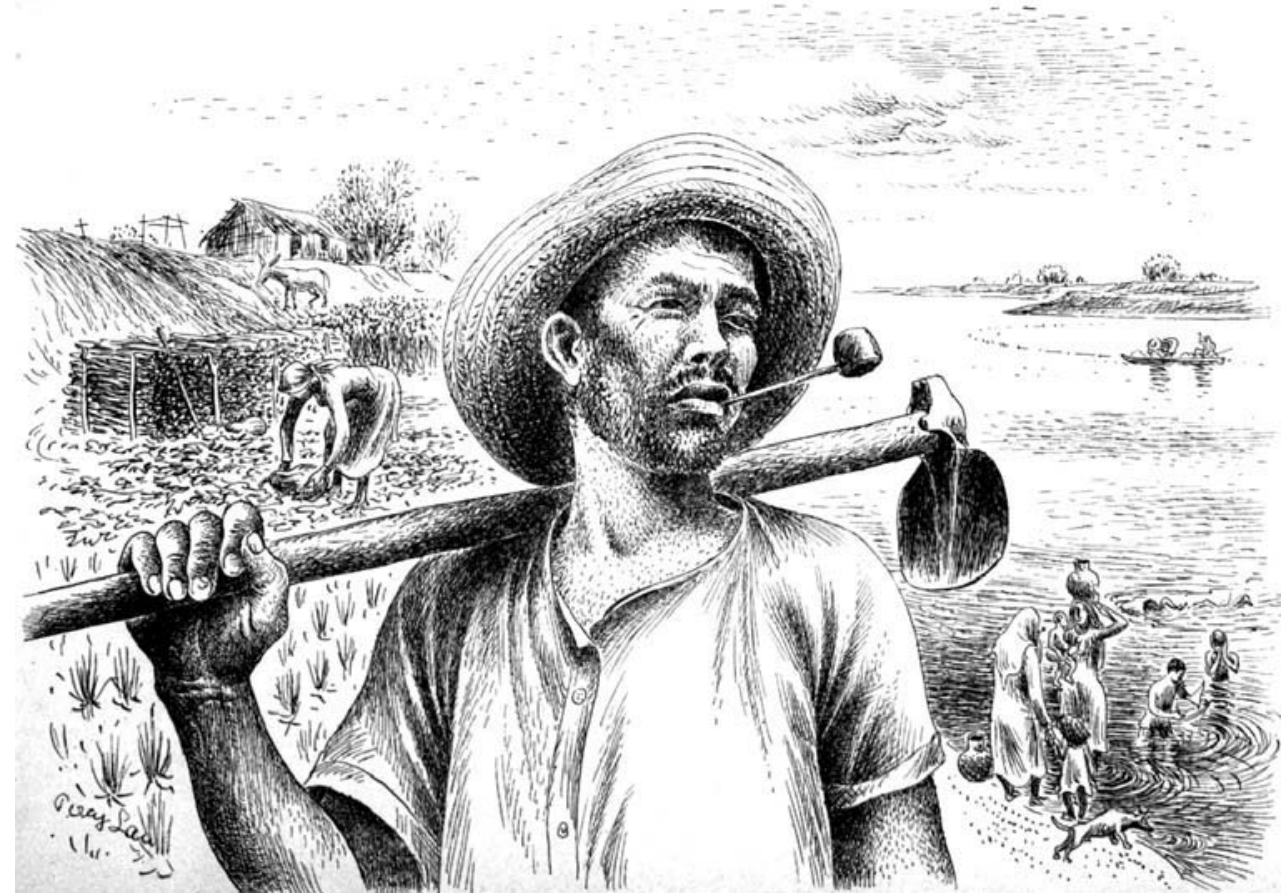

Figura 34 - Ribeirinhos do São Francisco, desenho de Percy Lau para Tipos e aspectos do Brasil. Acervo da biblioteca do Instituto de Estudos Brasileiros da Universidade de São Paulo.

Descritas em suas variantes, as carroças tornam-se um personagem; no final do episódio observa-se que "ligadas intimamente aos hábitos e aos costumes do homem, elas ocupam lugar de relevo no folclore sulino e que como o carro de boi noutras regiões, a carreta do Sul foi e continua a ser um elemento de civilização e progresso". Em análises atuais como a de Giralda Seyferth lêse que a retórica nacionalista do Estado Novo volta-se até mesmo contra esses meios de transporte, pois usados pelos colonos estrangeiros - a "carroça polaca", estigmatizada como "pitoresca e suja", "pesada e baixa" é "culpada" pela deterioração das estradas - a carroça carrega os estigmas da condição do colono imigrante, cuja assimilação em nome da unidade nacional fazia parte da campanha de nacionalização, com a política de imposição da brasilidade ${ }^{46}$.

Mencionamos no início deste texto o contexto cultural da aparição de Tipos e aspectos, a criação das instituições geográficas e, especialmente, os periódicos da época, todos fartamente ilustrados, entre os quais a revista Geografia, já citada, que exibe fotografia da carroça citada acima, "carro típico", em artigo de Caio Prado Jr., Contribuição para o estudo de influências étnicas no Estado do Paraná. Caio Prado Jr. escreve também sobre a "indústria salineira" comprovando a circulação de um repertório temático-imagético do país entre os intelectuais, mesmo entre os da vanguarda que buscam interpretálo de outra maneira ${ }^{47}$.

A penúltima cena que escolhi para comentar é uma das mais comuns da representação do Brasil desde o século XVI, presente nas descrições e imagens 


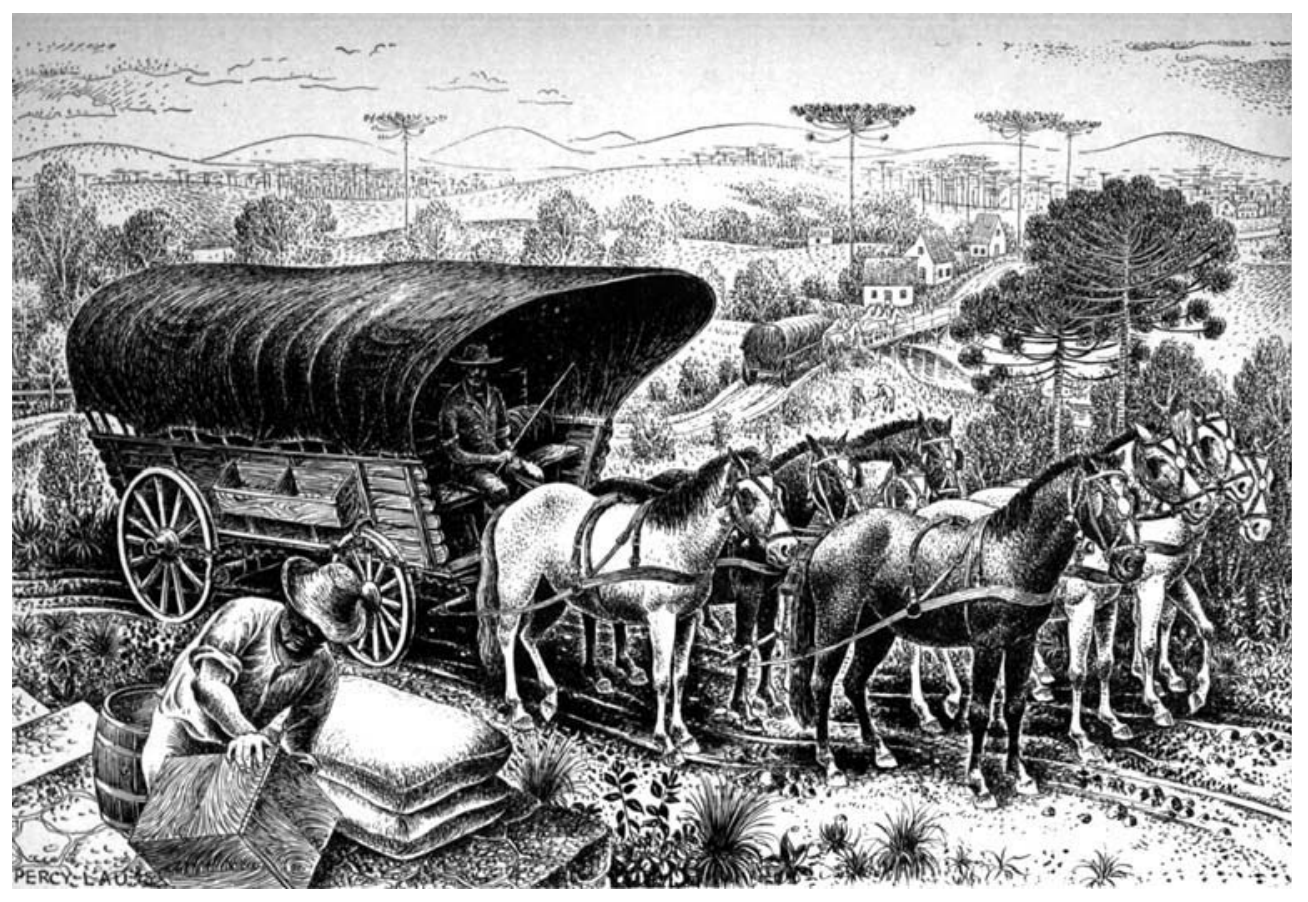

Figura 35 - Carroças coloniais do Sul, desenho de Percy Lau para Tipos e aspectos do Brasil. Acervo da biblioteca do Instituto de Estudos Brasileiros da Universidade de São Paulo.

do país ${ }^{48}$, reafirmada nos periódicos dos anos 1930 -1940: a da derrubada das florestas (Figura 36), objeto de descrição dos geógrafos, entre eles Pierre Monbeig, em textos e imagens que vão de 1935 aos anos 1970, do oeste paulista e norte do Paraná à Amazônia. A mencionada lista do "Arquivo fotográfico do geógrafo", que fixa um tema ou um "plano para fotografias geográficas do Brasil", inclui a "queimada" e o "transporte de toras". O texto que acompanha a imagem da derrubada nos Tipos e aspectos não deixa de ser "ecologicamente correto" para seu tempo: "progressivamente, as florestas foram substituídas por culturas e os solos se esgotaram logo devido a um sistema agrícola primitivo [...], a floresta vai sendo recuada para o interior, onde ela é poupada somente nas vertentes mais íngremes e inacessíveis". Monbeig também explicita uma clara consciência ecológica em seus livros e artigos, já que a derrubada é uma paisagem típica das zonas pioneiras, seu tema de pesquisa. Há correspondências entre seus textos e fotografias e os desenhos dos episódios dos Tipos e aspectos; desses, alguns trechos não perderam a atualidade:

[...] a derrubada reflete muito bem o espírito de nossa agricultura migratória e quase exclusivamente de especulação. Enquanto as florestas não desaparecerem do Brasil, este espírito dominará. O estado de São Paulo tem uma porcentagem de florestas inferior a de países altamente povoados da Europa. [...] A derrubada é um elemento comum à paisagem brasileira onde se superpõem o passado, o presente e o futuro: regiões desnudas e esgotadas, cobertas de pastagens pobres que mal servem para alimentar algumas cabeças de gado ou para culturas decadentes; outras regiões onde ainda há florestas para serem cortadas,
48. Para lembrar apenas algumas imagens emblemáticas: no mapa do Atlas Miller, de 1519, vêse as árvores sendo cortadas e os troncos levados nas costas dos indígenas; pouco depois, em 1575 , numa das estampas gravadas da Cosmographie universelle, de André Thevet, a legenda fala por si só: "Comme ce peuple coupe et porte le Brésil vers les navires"; na contemporaneidade dos Tipos e aspectos, as fotografias da Cia. de Terras do Norte do Paraná, para citar apenas um exemplo, exibem as paisagens dos desmatamentos intensivos, com os troncos no chão e os restos da floresta como pano de fundo, compondo uma representação típica da época; hoje ainda são comuns as cenas de desmatamento da Amazônia e em documentários televisivos europeus, portos, como o de La Rochelle, continuam recebendo cargas de madeiras das florestas brasileiras e africanas. 


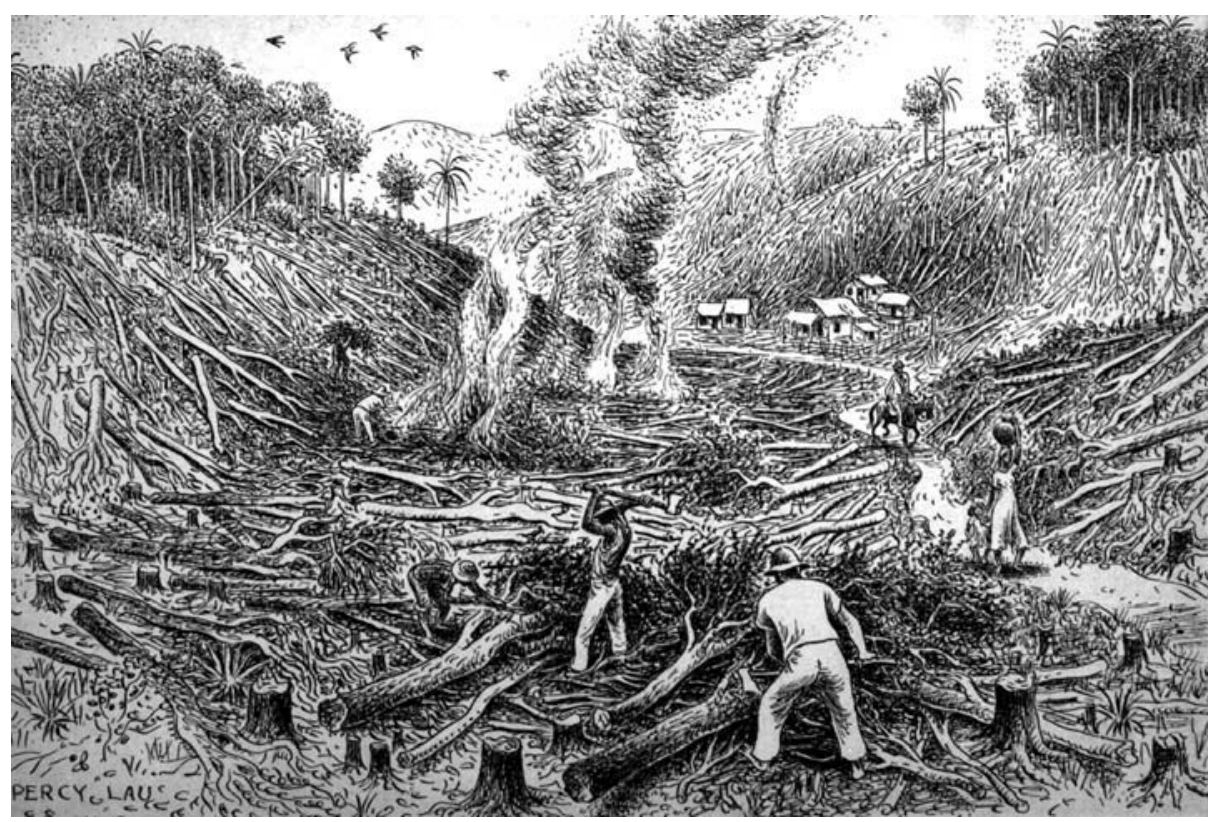

Figura 36 - Derrubada, na região Centro-Oeste, desenho de Percy Lau para Tipos e aspectos do Brasil. Acervo da biblioteca do Instituto de Estudos Brasileiros da Universidade de São Paulo.

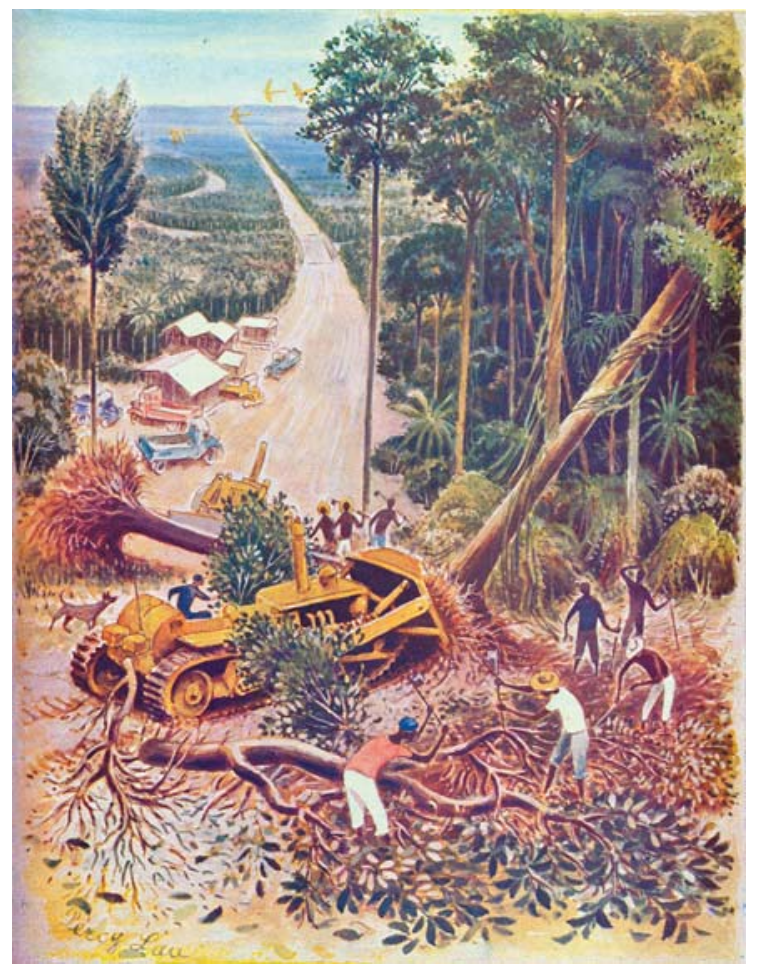

Figura 37 - Transamazônica, desenho de Percy Lau (em cores) para a décima edição atualizada e ampliada de Tipos e aspectos do Brasil, em 1975. Acervo da biblioteca do Instituto de Estudos Brasileiros da Universidade de São Paulo. 


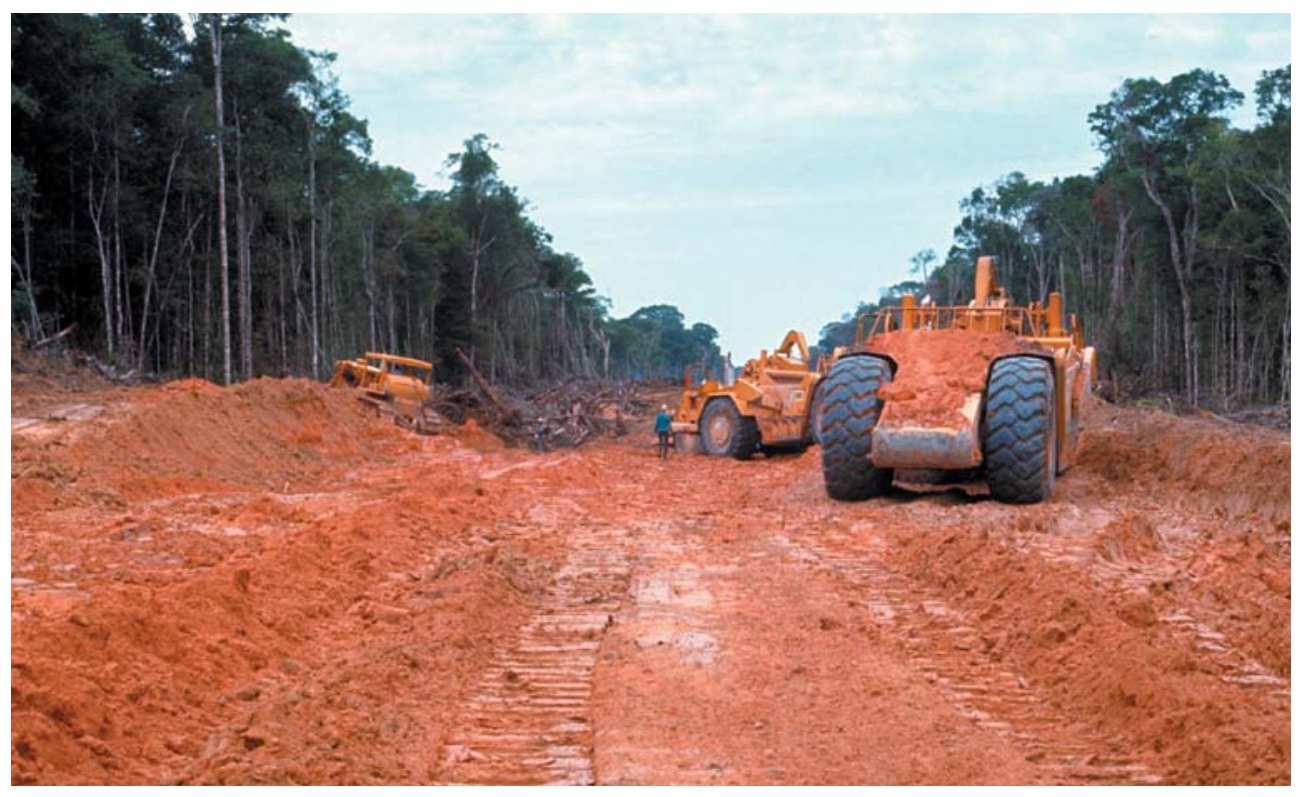

49. Cf. AQUINO, 1957. Alguns escultores são citados: Germaine Richier, Giacometti, Mingusi, Maria Martins - penso em Krajcberg, que, porém, está ausente da lista.A circulação da representação passa também pela pintura, em que a referência é Firmino Saldanha. Nas raras legendas de Marcel Gautherot ele denomina os troncos secos como personnages de la forêt.

Figura 38 - Transamazônica: desmatamento e construção da estrada, 1972. Fotografia de Pierre Monbeig. Copyright PRODIG/ CNRS, Paris.

mas onde as culturas não dão mais os lucros dos primeiros tempos e finalmente as zonas pioneiras onde os troncos se elevam solitários em meio a plantações ainda recentes.

A denúncia da destruição das florestas ou a louvação de suas formas aparece na poética desolada dos troncos secos ou calcinados, fotografados em série por Marcel Gautherot ao longo dos anos 1950; entre essas imagens algumas estão em ensaio fotográfico da revista Módulo, onde os troncos assumem "uma expressão artística" na relação arte/natureza/realidade ${ }^{49}$.

Para terminar com esta análise de algumas representações iconográficas e textuais da série dos Tipos e aspectos e antes de complementar minhas reflexões, tomo um dos últimos desenhos (desta feita em cores) de Percy Lau, que morreu logo depois; há apenas dois desenhos coloridos, publicados na décima edição em português, datada de 1975: o episódio é sobre a Transamazônica, que contraponho a uma fotografia de Pierre Monbeig, em 1972 (Figuras 37 e 38).

Ora, o que representa então a imagem dessa tão discutida estrada na fortuna crítica da obra em relação aos seus objetivos de 30 anos antes? Estamos em plena ditadura militar e a palavra-chave na época, que justifica a construção de duas rodovias que se cruzam la Transamazônica com 5 mil km e a Cuiabá-Santarém com 1.500), é "integração", "missão histórica" a cumprir, afirma-se, tendo em vista "um equilíbrio regional mais efetivo", pois a Amazônia, representando $42 \%$ do território nacional, sempre contou com uma ocupação descontínua, 3,4\% da população do país com uma renda de $2 \%$ em relação ao total da renda nacional - estes dados são do texto de 1975. A descentralização regional, o isolamento e a necessidade de absorção da mão- 
50. Empresto as expressões de um outro contexto finamente analisado por Marie-Claire Robic deixando a sugestão de análises que não caberiam no âmbito dessa pesquisa, ver ROBIC, 2000

51. THIESSE, $1995 \mathrm{e}$ 2001, p. 17.

52. Contamos com estudos a respeito desses grupos: ver MICELI, 2001. de-obra do Nordeste justificavam a "epopéia" da construção dessas estradas, bem como a ocupação do território e a colonização agrícola, objeto então de projetos oficiais. As riquezas potenciais da região são louvadas ao longo do texto, a articulação estradas/rios em uma malha utópica tantas vezes presente na história das intervenções no território brasileiro vêm à tona, reafirmando a busca da "unidade da comunidade nacional". Se o controle territorial de um país acompanha sempre a expansão espacial, a Amazônia, que representara sempre um lugar de fascinação no imaginário da "grande nação do futuro", afigurava-se como a última etapa do território a ser apropriada pelos seus habitantes. Pode-se pensar geograficamente no gesto clássico de "territorialização" nacional a cumprir, ou seja, na produção de um espaço e sua apropriação simbólica ${ }^{50}$

Se a série dos Tipos e aspectos do Brasil que atravessou gerações serviu a interesses ideológicos e pedagógicos imediatos do regime que os construiu, não penso que ela seja só fruto de uma estratégia do Estado autoritário de 1937 - autores já afirmaram que não há forma de governo específico para a construção identitária ${ }^{51}$, não havendo nada mais internacional do que a valorização de formas etnográficas das identidades nacionais a partir do final do século XIX e por ocasião, justamente, do regionalismo folclorista dos anos 30, citado acima -, os paralelismos entre as afirmações identitárias confirmam, porém, tanto sua associação a projetos políticos quanto a "regimes de historicidade", assim como as representações nacionais seriam sobretudo transnacionais, embora sempre com variantes e especificidades.

Naquele momento em que a nação está se constituindo são as relações entre os diferentes grupos - do poder central às oligarquias dos estados dominantes, passando pelos intelectuais do serviço público, burocratas/ funcionários a serviço da cultura ${ }^{52}$ e pelos construtores das representações que se relacionam com eles, artistas e estrangeiros trabalhando no país, com todos os credos confundidos e diferentes níveis de dependência ou compromisso que definem modelos de tipos exemplares e paisagens representativas. Gautherot, por exemplo, que fotografa para o SPHAN, encontra meios de usufruir de uma relativa independência nas viagens a serviço do órgão, fazendo também seus trabalhos pessoais, como explica Lygia Segala.

Em meio a tantas questões e paradoxos, é bom relembrar também que a nação está representada de maneira incompleta no repertório dos Tipos e aspectos, pois afinal éramos também um país de imigração e os imigrantes foram praticamente excluídos das séries de Gautherot, fotógrafo imigrante que se destaca em meio a tantos que ficaram no anonimato. Reitero a importância da noção de geração, de círculo de afinidades seletivas, de itinerários comuns e trajetórias convergentes, de aproximação entre idéias literárias, concepções de história e de geografia internacionais em circulação, para contextualizar melhor as formas de representação nacional, mesmo essas que se dão em períodos de definição de expressões nacionais organizadas no seio do Estado.

$\mathrm{Na}$ verdade, questões complexas virão certamente à tona na leitura deste texto, cujas respostas ainda não me parecem todas possíveis dada a falta 
de pesquisas aprofundadas no país quanto a uma "iconologia geográfica" ${ }^{53} \mathrm{e}$ seus desdobramentos, ponto que nos interessa particularmente neste estudo de caso. As linhas tomadas pela geografia brasileira ou melhor a cegueira pela história e epistemologia de textos e imagens que vigorou, lamentavelmente, por decênios, impediu que se estudasse os Tipos e aspectos até recentemente silêncio e ignorância que se estendem a tantos outros temas correlatos. Porém, essas imagens-ícone de inscrição territorial e humana, esse registro de tipos e paisagens emblemáticas que tiveram ampla difusão ${ }^{54}$ na longa duração e que parecem hoje simplesmente "folclóricos", "pitorescos" ou anacrônicos aos olhos de quem jamais percorreu o interior do país, permanecem com variações de pouca monta, sendo explorados pela publicidade turística ou revividos em momentos circunstanciais (Ano Brasil na França), quando se reiteram clichês já instalados na memória visual de determinados segmentos da sociedade. Vê-las tanto na complexidade da formação de um repertório oficial de representações do país quanto nas modalidades diversas de sua continuidade e recepção, inscrevendo-as em novas leituras da história, da geografia e das outras ciências sociais no Brasil, parece-me um trabalho fecundo, ainda por fazer.

As formas de "intericonixidade", as constantes ou os contextos de "vizinhança visual" 55 sugeridos neste texto são apenas um esboço de análises seriais e interdisciplinares da construção de representações e de convenções visuais em coleções nacionais, nos anos 1930-1960 - o cruzamento das séries de Marcel Gautherot, com exemplos pinçados aqui e ali em corpus iconográficos oriundos de experiências de deslocamento diversas e peculiares, encaradas como "formas da experiência" cujas "intenções" em diferentes níveis não são jamais transparentes, é parte da pesquisa que deve destacar o percurso das representações aos ícones nos contextos culturais convergentes da história da arte e da antropologia.

\section{REFERÊNCIAS}

ANGOTTI-SALGUEIRO, H.A paisagem na óptica geográfica. In: ANGOTTI-SALGUEIRO, H (Dir.), Paisagem e arte. A invenção da natureza, a evolução do olhar. São Paulo: CNPq/CBHA/Fapesp, 2000 .

(Dir). Pierre Monbeig e a geografia humana brasileira.A dinâmica da transformação. Bauru: Edusc/Fapesp/IEB, 2006 (no prelo).

AQUINO, F.A natureza faz escultura. Módulo, Rio de Janeiro, fev., 1957.

ARBAUD, J.d'. Ceux de la Provence. Types et coutumes. Paris: Horizons de France, 1939.

BON,A. Brésil. Deux cent dix-sept photographies de A. Bon, M. Gautherot et P.Verger. Introduction de A.Amoroso Lima. Paris: Paul Hartmann Éditeur, 1950.

CLAVAL, P. Histoire de la géographie française, de 1870 à nos jours. Paris: Nathan, 1998.
53. Destaco, à guisa de metodologia exemplar de representações nacionais, MENDIBIL, 1999, e o seu capítulo Paul Vidal de la Blache, le 'dresseur d'images'. Essai sur l'iconographie de la France.Tableau géographique (1908) in ROBIC (Dir.), 2000, em que pesquisas em várias obras ilustradas levaram a gráficos das freqüências (temáticas dominantes) $\mathrm{e}$ registros de ocorrências imagéticas (local representado), comparação e interpretação de diferentes lógicas/sistemas iconográficos por obra/autor, na geografia francesa, de 1840 a 1950 .

54.As imagens-ícones de Tipos e aspectos bem além do projeto pedagógico do Estado Novo conheceram uma ampla difusão também no exterior nos anos 1950-1960. Títulos esquecidos hoje como o do sociólogo-brasilianista T. Lynn Smith, Brazil. People and Institutions, presente na biblioteca de Pierre Monbeig, com dedicatória do autor, publicado em 1963, usa imagens da série de Percy Lau para mostrar o país como um "cultural mosaic", onde se encontram "the most extraordinary cultural diversities, richest panoramas of natural contrasts, human types and cultural forms to be found in the world". No Brasil, além dos livros didáticos, há empregos curiosos das cenas: a do Boiadeiro (fig. 30) é retomada no memorial do Plano Piloto apresentado pela equipe de Vilanova Artigas, no concurso de Brasília - esse desenho acompanha o projeto na revista $M o ́ d u$ lo, n. 8, julho de 1957.

55. Expressões tomadas de empréstimo a Didier Mendibil; ver artigos citados e seu texto a ser publicado em português 
"O sistema iconográfico da geografia clássica francesa e Pierre Monbeig" in ANGOTTI-SALGUEIRO, 2006
COSTA, H. Palco de uma história desejada: o retrato do Brasil por Jean Manzon. Revista do Patrimônio Histórico e Artístico Nacional, Brasília, n. 27, 1998.

CUNHA, E. da. Os sertões - Campanha de Canudos. (Edição, prefácio, cronologia e índices de Leopoldo M. Bernucci). São Paulo:Ateliê Editorial/Imprensa Oficial/Arquivo do Estado, 2001.

DAOU,A. M.Tipos e aspectos do Brasil: a paisagem cultural brasileira na iconografia de Percy Lau. Simpósio Nacional sobre Espaço e Cultura, UERJ, 2000 (ms).

DEFFONTAINES, P. Pays et paysages de l'état de Saint-Paul. Première esquisse de division régionale. Annales de Géographie, Paris, t.45, 1936.

Les personnages-types du Brésil. Revue de Deux Mondes, Paris, fev., 1936.

Petit guide du voyageur actif. Comment connaître et comprendre un coin de pays, 2a. ed. Paris: Édition Sociale Française, 1943.

DEFFONTAINES, P.; OLIVEIRA, C.A. B. de. Pequeno guia do viajante ativo. Geografia, São Paulo, ano II, n. 4, 1936.

DUARTE, Dioclécio. A indústria extrativa do sal e a sua importância na economia do Brasil. Rio de Janeiro: Serviço de Informação Agrícola, 1941.

FARIA, L. de C. Nacionalismo, nacionalismos - dualidade e polimorfia. À guisa de depoimento e reflexão. In:CHUVA, M.(Org.).A invenção do patrimônio: continuidade e ruptura na construção de uma política de preservação no Brasil. Rio de Janeiro: MEC/IPHAN, 1995.

FAURE, C. Le projet culturel de Vichy: folklore et révolution nationale: 1940-1944. Lyon: Presses Universitaires de Lyon/CNRS, 1989.

GARCIA JR.,A. Les intellectuels et la conscience nationale au Brésil.Actes de la Recherche en Sciences Sociales, Paris, n. 98, junho de 1993.

Les métissages et la construction culturelle de la nation. Hérodote. Revue de Géographie et de Géopolitique, Paris, n. 98, 2000.

GIBERT,A. La géographie psychologique. Revista Brasileira de Geografia, Rio de Janeiro, out., 1939.

GORGUS, N. Le magicien des vitrines. Le muséologue Georges Henri Rivière. Paris: Éditions de la Maison des Sciences de l'Homme, 2003.

GUIOMAR,J-Y. Le tableau de la géographie de la France. In: NORA, P.(Dir.). Les lieux de mémoire, v. II (La Nation). Paris: Gallimard, 1986.

HARDY, G. La géographie psychologique. Paris: Gallimard, 1939.

HARTOG, F. Régimes d'historicité. Présentisme et expérience du temps. Paris: Seuil, 2004. 
LEBOVICS, H.La “Vrai France”. Les enjeux de l'identité culturelle, 1900-1945. Paris:Éd.Belin,1995.

MANZON, J. Flagrantes do Brasil. Rio de Janeiro: Bloch, 1950.

MENDIBIL, D. Essai d'iconologie géographique. L'Espace Geographique, Paris, t. 28, n. 4, 1999.

Paul Vidal de la Blache, le 'dresseur d'images'. Essai sur l'iconographie de la France. Tableau géographique (1908). In: ROBIC, M.-C. (Dir.). Le tableau de la géographie de la France de Paul Vidal de la Blache. Dans le labyrinthe des formes. Paris: Éd. du CTHS, 2000.

MICELI, S. Intelectuais à brasileira. São Paulo: Companhia das Letras, 2001.

MIRANDA, N. Études cartographiques des Tabous alimentaires et des Danses populaires. Travaux du 1er Congrès International de Folklore (Tenu à Paris, du 23 au 28 août 1937, à l'École du Louvre).Tours:Arrault et Cie, Imprimeurs, 1938.

MONBEIG, P. Capital e geografia. Novos estudos de geografia bumana brasileira. São Paulo: Difusão Européia do Livro, 1957.

Les modes de penser dans la géographie humaine. In: ÉVENTAIL de l'histoire vivante. Hommage á Lucien Febvre offert par l'amitié d'historiens, linguistes, géographes, économistes, sociologues, ethnologues. Paris:Armand Colin, 1953.

Observações sobre o estado atual dos estudos geográficos no Brasil. Rumo, Rio de Janeiro, ano I, $4^{\circ}$ sem., 1943.

Novos estudos de geografia humana. São Paulo: Difusão Européia do Livro, 1957.

ORLANDI, J. O.Arquivo fotográfico do geógrafo. Geografia, São Paulo, ano II, n.4, 1936.

OZOUF-MARIGNIER, M-V. Um campo de estudos contestado: a geografia psicológica no tempo de Pierre Monbeig. In:ANGOTTI-SALGUEIRO, H. (Dir.). Pierre Monbeig e a geografia humana brasileira. A dinâmica da transformação. Bauru: Edusc/Fapesp/IEB, 2006 (no prelo).

PASSERON, J.-C. Biographies, flux, itinéraires, trajectoires. Revue Française de Sociologie, Paris, n. $1,1990$.

PONTES, H. Retratos do Brasil: editores, editoras e coleção brasiliana, nas décadas de 30, 40 e 50. In: MICELI, S. (Org.). História das ciências sociais no Brasil. São Paulo:Vértice/Revista dos Tribunais/Idesp, 1989, v. 1.

ROBIC,M.-C.Territorialiser la nation.Le Tableau entre géographie historique, géographie politique, géographie humaine. In: ROBIC, M.-C. (Dir.). Le Tableau de la géographie de la France de Paul Vidal de la Blache. Dans le labyrinthe des formes. Paris: Éd. du CTHS, 2000.

Rencontre et voisinages de deux disciplines. Ethnologie Française, Paris, XXXIV, n. 4, 2004.

ROUILLÉ,A. La photographie. Entre document et art contemporain. Paris: Galimard, 2005. 
SEGALA, L. Fotografia, folclore e cultura popular. Cadernos de Antropologia e Imagem, Rio de Janeiro, v. 8, 2000.

SEYFERTH,G.A assimilação dos imigrantes como questão nacional.Mana:Estudos de Antropologia Social, Rio de Janeiro, v. 3, n. 1, 1997.

SMITH,T. L. Brazil. People and Institutions. Baton Rouge: Louisina State University Press, 1963.

THIESSE,A.-M. La petite patrie enclose dans la grande: regionalismo e identidade nacional na França durante a Terceira República (1870-1940). Estudos Históricos, Rio de Janeiro, n. 15, 1995.

Ils apprenaient la France. L'exaltation des régions dans le discours patriotique. Paris: Maison des Sciences de l'Homme, 1997.

Petite et grande patrie. In: Le GOFF, J. (Dir.). Patrimoine et passions identitaires. Actes des Entretiens du Patrimoine. Paris: Fayard, 1998.

La création des identités nationales. Europe XVIIIe-XXe siècle. 2. ed. Paris: Seuil, 2001.

TIPOS e aspectos do Brasil (excertos da Revista Brasileira de Geografia). Ilustrações de Percy Lau, $6^{a}$ ed. Rio de Janeiro: IBGE/Conselho Nacional de Geografia, 1956.

VIANNA, F. J. O. O tipo brasileiro, seus elementos formadores. In: DICCIONARIO bistorico, geographico e ethnographico do Brasil (Introdução geral). Rio de Janeiro: Imprensa Nacional, 1922, v. 1.

VLACH,V. R, F. L'instauration de l'État-Nation Brésil. 1930-1960, Vargas et Kubitschek. Des leaders, des militaires et des géopoliticiens. Hérodote. Revue de Géographie et de Géopolitique, Paris, n. $98,2000$.

WALTER, F. Les figures paysagères de la Nation.Territoire et paysage en Europe (16e-20e siècle). Paris: Éditions de l'École des Hautes Études en Sciences Sociales, 2004.

XEXÉO, M. F. B. Prefácio. In: PERCY Lau, um desenhista e seu traço. Rio de Janeiro: MNBA, 2000.

Artigo apresentado em 08/2005. Aprovado em 09/2005. 